T.C.

MARMARA ÜNIVERSITESİ

SOSYAL BİLIMLER ENSTITÜSÜ

İNGILIZIZCE İŞLETME ANABİLIM DALI

ÜRETIMM YÖNETIMİ VE PAZARLAMA (İNGILİZCE) BİLIMM DALI

SOCIAL MEDIA MARKETING: EXPLORING THE USER TYPOLOGY IN TURKEY

Yüksek Lisans Tezi

MESUT Çİ̧EK

ISTANBUL, 2012 
T.C.

MARMARA ÜNIVERSITESI

SOSYAL BİLIMLER ENSTITÜSÜ

İNGILIIZCE İŞLETME ANABİLIM DALI

ÜRETIMM YÖNETIMİ VE PAZARLAMA (İNGILİZCE) BİLIMM DALI

SOCIAL MEDIA MARKETING: EXPLORING THE USER TYPOLOGY IN TURKEY

\author{
Yüksek Lisans Tezi \\ MESUT ÇIÇEK \\ Danışman: DOÇ. DR. İREM EREN ERDOĞMUŞ
}

ISTANBUL, 2012 


\section{Marmara Universitesi \\ Sosyal Bilimler Enstitūsũ Mũdürlūğú}

\section{Tez Onay Belgesi}

IŞLETME Anabilim Dalı ORETIM YONETIMII VE PAZARLAMA(ING) Bliim Dalı Yüksek Lisans oğrencisi MESUT ClCCEK nın SOCIAL MEDIA MARKETING: EXPLORING THE USER TYPOLOGY IN TURKEY adh tez çalışması , Enstitümüz Yonetim Kurulunun 24.04.2012 tarih ve 2012-10/11 sayil karariyla oluşturulan jür tarafindan oybirligivoyçokluğu ilo Yoksek Lisans Tezi olarak kabul edilmiştir.

Tez Savunma Tarihi $\quad: 08,105,2012$

1) Tez Danısmanı : DOÇ. DR. ÍREM ERDOGMUS

2) Jüri Öyesi $\quad$ : DOÇ. DR. EMINE COBANOḠLU

3) Jüri Oyesi : DOC,. DR. MUSTAFA KURT

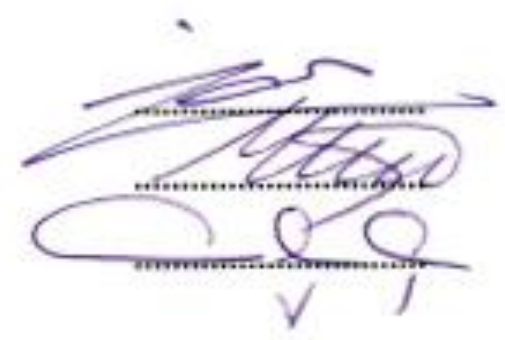




\section{ACKNOWLEDGEMENTS}

First and foremost I offer my sincerest gratitude to my supervisor, Assoc. Prof. Dr. İrem Eren Erdoğmuş, who has supported me thoughout my thesis with her patience and knowledge whilst allowing me the room to work in my own way. I attribute the level of my Masters degree to her encouragement and effort and without her this thesis, too, would not have been completed or written. One simply could not wish for a better or friendlier supervisor.

I am grateful for different opinions, viewpoints and constructive comments offered me by Prof. Dr. Zeynep Bilgin, Assoc. Prof. Dr. Emine Çobanoğlu and Assoc. Prof. Dr. A. Müge Yalçın.

I am most grateful to my colleagues Ramazan Nacar, Fatih Geçti and Volkan Polat who provided me their generous assistances and supports for creation of this thesis throughout the year.

Finally, I am sincerely thankful to my wife, Funda Çiçek, and my family for their patience, support and contribution providing me the capability to create this thesis.

Mesut ÇİÇEK

İstanbul, 2012 


\title{
SOCIAL MEDIA MARKETING: EXPLORING THE USER TYPOLOGY IN TURKEY
}

\begin{abstract}
Social Media has led to a drastic change in the way of doing business. One of the most important impacts and contributions of social media has been on marketing especially segmentation, branding, customer relationship management, marketing research and promotion. Given the opportunities it provides, companies to analyze and understand this new generation digital world, and develop their social media marketing strategies well ahead in order to be successful in this new era. The starting step should be to understand who the users are, and how they behave. To do that, classifying diverse user behaviors into meaningful categories of user types, according to the frequency of use, variety of use and content preferences are very important.

Mainly Inspired by the Social Technographic Model, the primary objective of this study is to classify the users according to their usage preferences of social media activities; and determine their demographic affinities and content preferences. A secondary objective is to explore what are the motivations to be present and/ or actively use social media tools. For this purpose, an exploratory research and a descriptive research are conducted in Turkey. The exploratory research provides insights for motivations of using social media in Turkey. On the other hand, the descriptive research is applied to cluster the users according to their preferences on social media. A likert type questionnaire is developed and applied to 1001 social media users in Turkey. Then, the data was tested with cluster analysis, factor analysis, ANOVA, chi-square, and scheffe tests using SPSS version 17.0 .
\end{abstract}

Keywords: Social Media, Social Media Marketing, Web 2.0, Typology, Cluster Analysis 


\title{
SOSYAL MEDYA PAZARLAMASI: TURKIYY'DEKİ KULLANICI TIPOLOJISININ KEŞFEDILMESI
}

\begin{abstract}
ÖZET
Sosyal Medya firmaların iş yapış şekillerinde önemli değişikliklere neden olmuştur. Sosyal medya özellikle bölümleme, markalaşma, müşteri ilişkileri yönetimi, pazar araştırması ve tutundurma ile ilgili pazarlama stratejilerinin uygulanmasında firmalara önemli ölçüde firsat sağlar. Bu firsatları doğru ve etkin bir şekilde değerlendirebilmek için firmalar bu yeni dijital dünyayı iyi analiz etmeli ve anlamalıdırlar. Böylece cağın gerisinde kalmadan başarılı sosyal medya pazarlama stratejileri geliştirebilirler. Etkin Stratejiler geliştirebilmek için firmaların başlangıç adımı sosyal medya kullanıcılarının kimler olduğunu bu kullanıcıların digital dünyada nasıl davrandıklarını anlamak olmalıdır. Bu amaçla tüketicileri sosyal medya araçlarını kullanım sıklığı, çeşitliliği ve tercihlerine göre gruplandırmak ve her grubun özelliklerini belirlemek oldukça önemlidir.

Sosyal Teknografik Model'den esinlenilerek geliştirilen bu çalışmanın esas amacı tüketicileri sosyal medyadaki aktivite tercihlerine göre gruplandırmak ve her grubun demographic özellikleri ile içerik tercihlerini belirlemektir. Çalışmanın ikincil amacı ise tüketicilerin sosyal medya araçlarını kullanım motivasyonlarının keşfedilemesidir. $\mathrm{Bu}$ amaçla çalışamada hem keşifsel hemde betimsel araştırma teknikleri kullanılmıştır. Keşifsel çalışmada Türkiye'deki sosyal medya kullanıcılarının motivasyonlarının anlaşılması amaçlanmıştır. Diğer taraftan, betimsel araştırmada kullanıcıların sosyal medya aktivite tercihlerine göre gruplandırılmasına çalışılmıştır. Çalışmada likert tipi sorularla oluşturulan anket Türkiye'de 1001 sosyal medya kullanıcına uygulanmış elde edilen veriler SPSS 17.0 sürümünde kümeleme analizi, faktör analizi, ANOVA, ki-kare ve scheffe testleri ile test edilmiştir.
\end{abstract}

Anahtar kelimeler: Sosyal Medya, Sosyal Medya Pazarlamas1, Web 2.0, Tipoloji, Kümeleme Analizi 
TABLE OF CONTENTS

LIST OF TABLES ......................................................................................

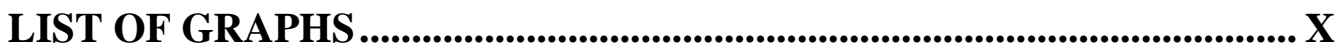

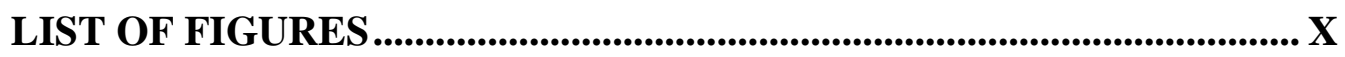

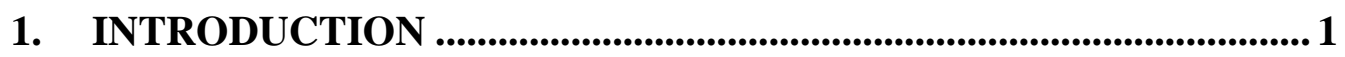

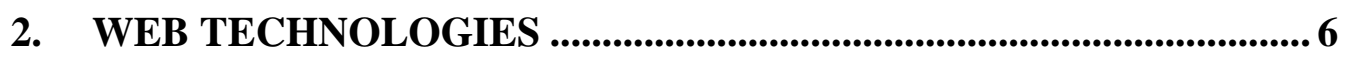

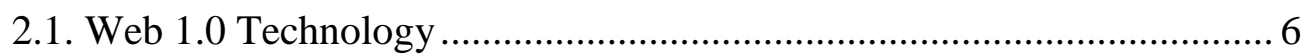

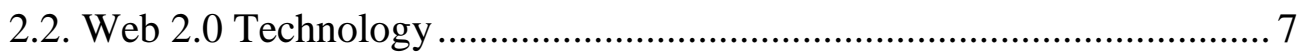

2.3. Main Differences between Web 1.0 and Web 2.0 ............................... 9

2.4. Through the Semantic Web: Web 3.0 .................................................. 10

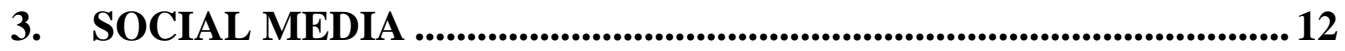

3.1. Definition of Social Media ......................................................... 12

3.2. Types of Social Media ................................................................ 13

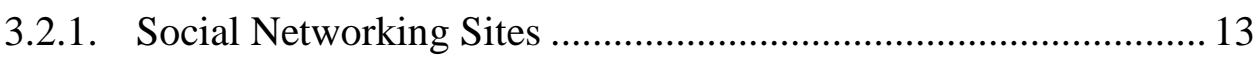

3.2.2. Content Communities: ............................................................... 16

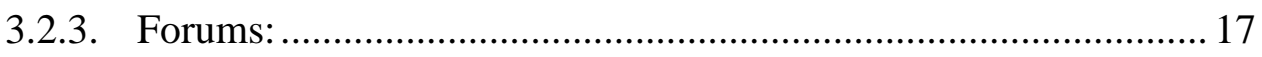

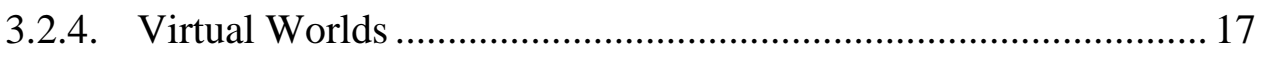

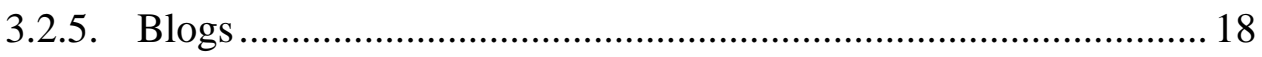

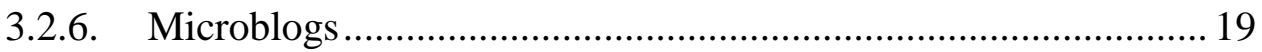

3.2.7. Social News Sites and Bookmarking......................................... 19

4. SOCIAL MEDIA AS A MARKETING TOOL ................................ 21

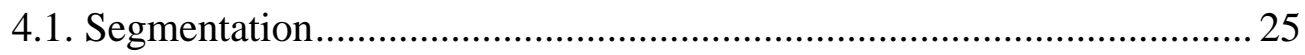

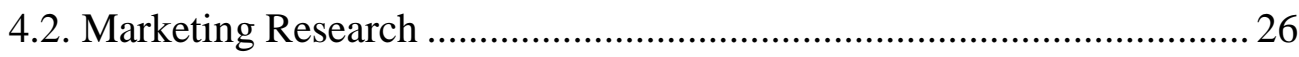




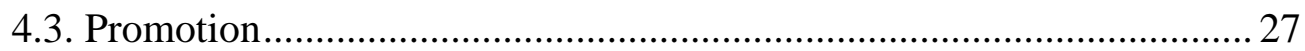

4.4. Customer Relationship Management .................................................29

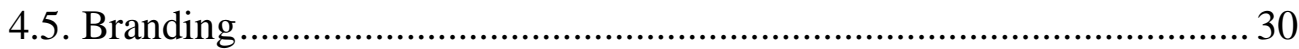

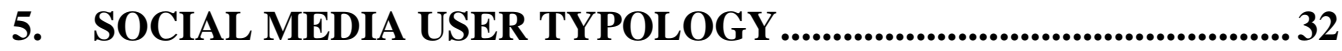

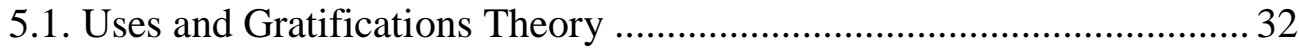

5.2. Social Technographic Model ............................................................ 34

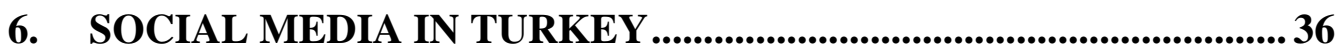

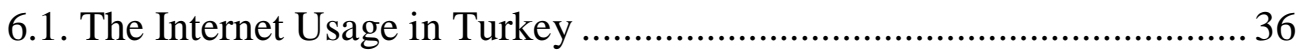

6.2. Social Media Usage in Turkey ........................................................ 40

7. RESEARCH DESIGN AND METHODOLOGY ..............................46

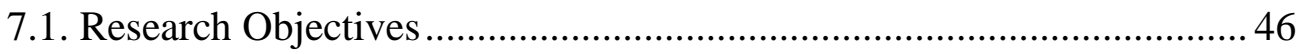

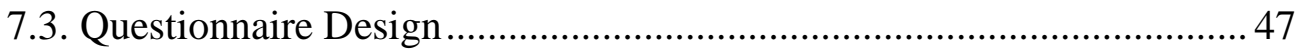

7.4. Sampling And Data Collection ......................................................... 48

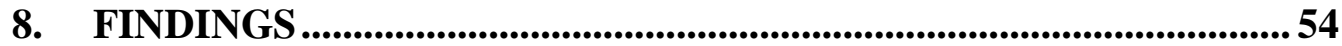

8.1. Descriptive Statistics for the Sample ................................................ 54

8.2. Motivation of using Social Media........................................................ 57

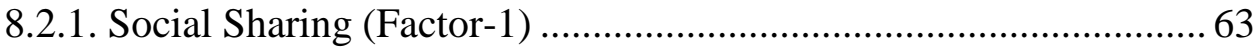

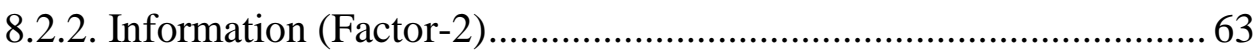

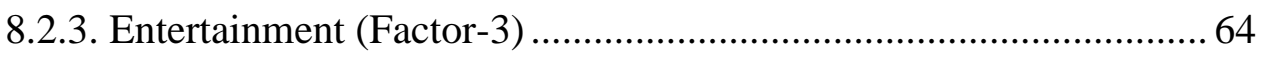

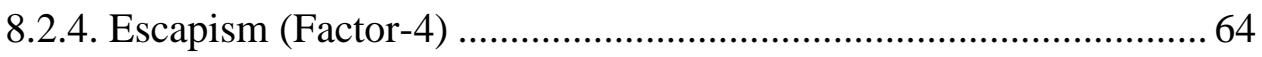

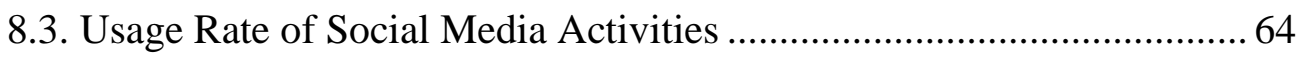

8.3.1. Usage of Content Communities and SNS's (Factor 1) ...................69

8.3.2. Usage of Blogs and Forums (Factor 2) .......................................... 69

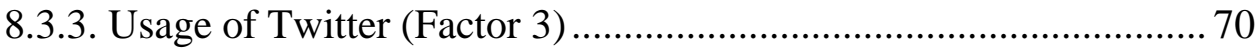

8.3.4. Usage of Virtual Platforms (Factor 4) ......................................... 70

8.4. Typology of the Social Media Users..................................................... 70 
8.4.2. The Nexus between Time Spend on the Internet and the Clusters.. 77

8.4.3. The Nexus between Social Media Usage Motivations and the Clusters

8.4.4. The Nexus between the Content Categories and the Clusters

8.4.5. The Nexus between the Following Companies on Social Media and the Clusters

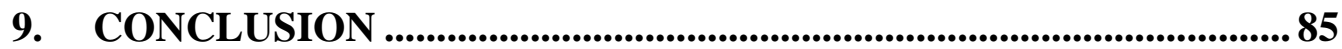

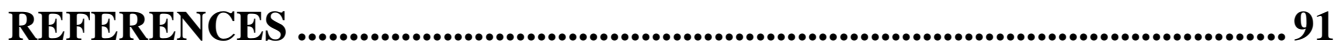

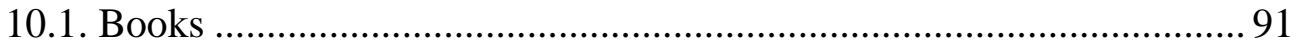

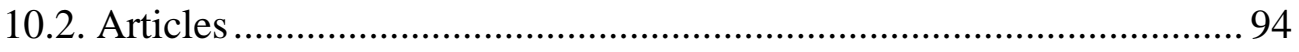

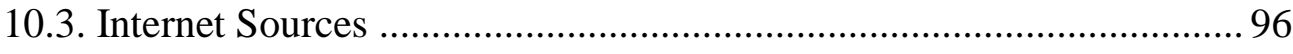

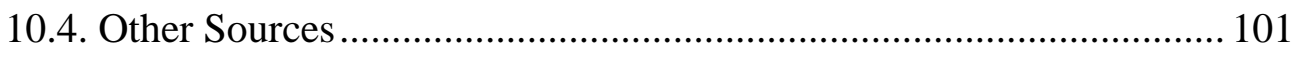

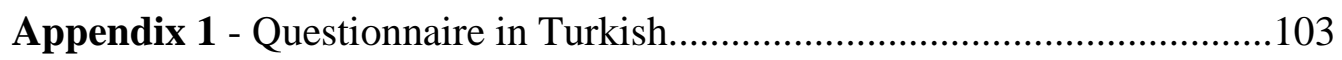

Appendix 2 - Questionnaire in English.......................................................107 


\section{LIST OF TABLES}

Table 1: Differences between Web 1.0 and Web 2.0 Technologies ........................... 9

Table 2: The Comparison of Old and New Marketing ............................................. 23

Table 3: Top Followed Turkish Brands on Facebook.............................................. 45

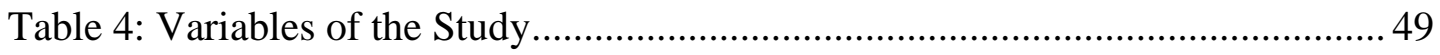

Table 5: Gender and Marital Status of the Sample .................................................. 54

Table 6: Occupation and Income Level of the Sample ............................................ 54

Table 7: Education Level and Age Distribution of the Sample .................................55

Table 9: The results of KMO and Bartlett tests of Motivations................................. 58

Table 10: Communalities of the Motivational Variables ............................................59

Table 11: The results of KMO and Bartlett Tests of Motivational Variables after

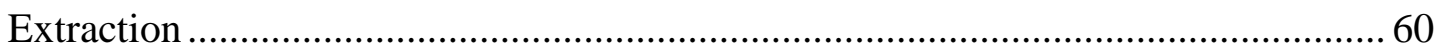

Table 12: Communalities for Motivational Variables after Extraction ......................60

Table 13: Total Variance Explained for Motivation Factors .................................... 61

Table 14: Rotated Component Matrix for Motivation Factors after extraction ......... 62

Table 15: Factor Analysis and Reliability for Motivation Factors ............................ 62

Table 16: The results of KMO and Bartlett Tests of Social Media Activities ........... 66

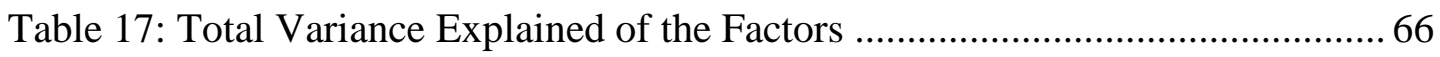

Table 18: Communalities of the Variables Related to the Social Media Activities .. 67

Table 19: Rotated Component Matrix of the Variables Related to the Social Media

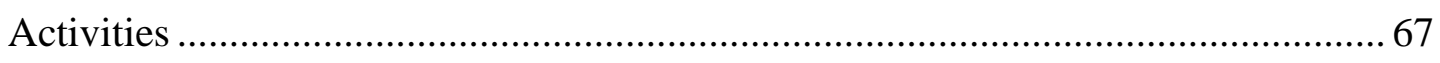

Table 20: Factor Analysis and Reliability for the Variables Related to the Social

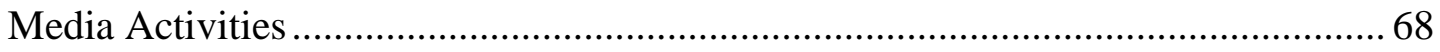

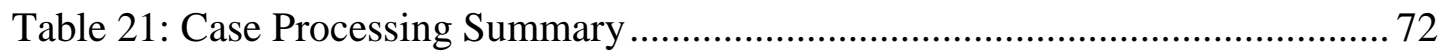

Table 22: Agglomeration Schedule for the Cluster Sample..................................... 72

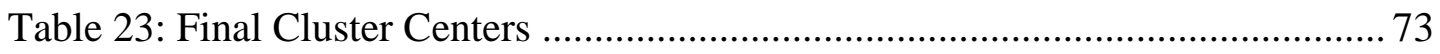

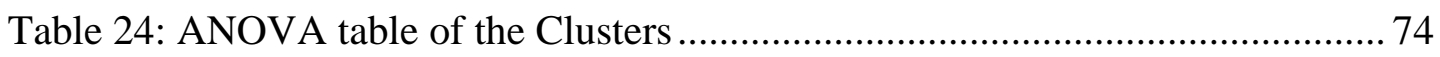

Table 25: Number of Cases in Each Cluster ............................................................. 74

Table 26: The demographic characteristics of the clusters ...................................... 75

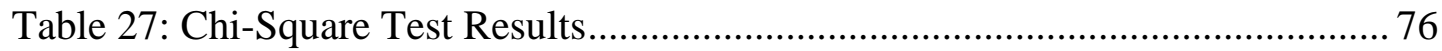


Table 28: ANOVA Table of the relationship between the Clusters and Motivation

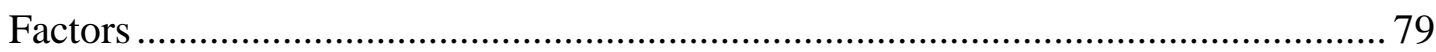

Table 29: Scheffe Test Results for the Sharing Factor .......................................... 80

Table 30:Scheffe Test Results for the Information Factor...................................... 80

Table 31: Scheffe Test Results for the Entertainment Factor ................................. 81

Table 32: Scheffe Test Results for the Escape Factor............................................. 81

Table 33:The relationship between the Content Categories and the Clusters............ 82

Table 34:Chi-Square test of the following companies on Social Media................... 83 


\section{LIST OF GRAPHS}

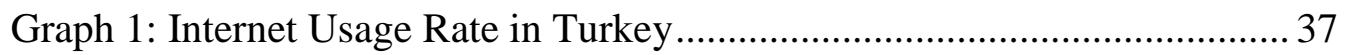

Graph 2: Internet Usage by Age Groups, 2009 ................................................ 38

Graph 3: Internet Usage by Educational Background, 2009 ............................ 38

Graph 4: Internet Usage by Employment Status, 2009 .................................... 39

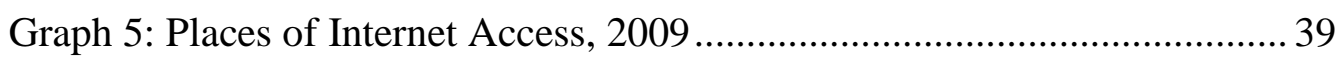

Graph 6: Top social media sites in Turkey ...................................................... 42

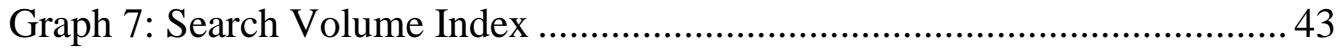

Graph 8: The number of Facebook Users in Turkey ...................................... 44

Graph 9: The age and the gender distribution of the Facebook users in Turkey ....... 44

Graph 10: Time spend on the Internet ............................................................... 56

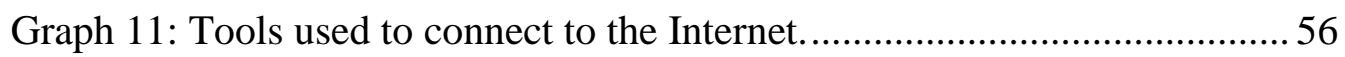

Graph 12: Means and Std. Deviation of the dependent variables for Q4 ........ 65

Graph 13: Average Internet Usage on Weekdays based on Clusters ............... 78

Graph 14: Average Internet Usage on Weekends based on Clusters ............... 78

Graph 15: The relationship between Following Companies on Social Media and the Clusters 84

\section{LIST OF FIGURES}

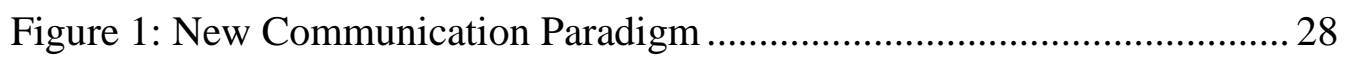

Figure 2: The Social Trinity Model ................................................................ 31

Figure 3: Social Media Landscape for Turkey ............................................... 41 


\section{INTRODUCTION}

Since the beginning of humanity nearly 150.000 - 200.000 years ago (Mellars, 2006), communication emerged as a means to survival and continuity of life by connecting people. Throughout history, societies used several techniques to communicate such as carrier pigeons, flags, smoke and later telex, telegraph and so on. Communication methods kept improving with time and technology. However, it was the Internet made a drastic change in the communication sphere. Since the Internet enables the entire World to connect together via World Wide Web technology, people and Institutions started to launch their Internet pages in order to reach a wider consumer audience. In the literature this era is called Web 1.0. However, these web sites had static infrastructures and limited functionalities. People could find only the information that companies released. In time, technology improved and a new era, which is called Web 2.0 or Social Media, has started on the Internet. Although the terms Social Media and Web 2.0 are often used as interchangeable (Constantinides and Fountain, 2008), it is important to make a distinction since Web 2.0 is platform on which social media is based upon (Carlsson, 2010). Kaplan and Haenlein (2010, p.60) define social media as "a group of Internet-based applications that build on the ideological and technological foundations of Web 2.0, and that allow the creation and exchange of User Generated Content (UGC)". Social Media consists of social networking sites, forums, virtual worlds, content communities, blogs, microblogs and social bookmarking sites. The key features of social media can be listed as two-way communication, rich content and information sharing both between the users and the companies as well as among the users themselves. Social media is becoming an important platform for marketing because the number of people getting involved in this new, exciting, and attractive media tool is increasing in number. There are more than one billion social media users in the world as of 2011 (Belleghem, 2011), even just Facebook has more than 800 million active users in total (Facebook, 2011). The percentage of the gender distribution of social media users change between $45 \%$ and $55 \%$ based on the characteristics of social media sites. In addition, people aged 18-34 have the highest concentration of visitors among all age groups (NIELSEN, 2011). One of the most impressive statistics about social media is more than $\% 50$ of the users follow brands on social media and 
average number of brands followed by per user is over 10 (Belleghem, 2011). In the light of these statistics, it can be argued that social media is replacing the position of traditional mass media day by day. These improvements also force the mass media companies and technology producers to built proactive strategies. For instance, new generation LCD and LED TV's have integrated Internet and social media tools that people may watch YouTube videos or may update their Facebook and Twitter status.

One of the most important impacts of social media has been on marketing. Weinberg (2009, p:3) defines social media marketing as "Social media marketing is a process that empowers individuals to promote their websites, products, or services through online social channels and to communicate with and tap into a much larger community that may not have been available via traditional advertising channels". Companies can communicate with their customers and get feedback from them; also customers can communicate with other customers and share the information about the products and services (Mangold and Faulds, 2009). Although social media affects almost all the fields of marketing, it can be most effectively utilized in segmentation, marketing research, promotion, branding, and customer relationship management. Social media's most significant influence is on segmentation, which is the first step in forming marketing strategy (Brandtzaeg, 2010). The users do not only provide demographic information, but also provide psychographic and behavioral information about themselves such as personality, lifestyle, activities, interests and opinions on social media world. Thus, it is possible to conduct psychographic and behavioral segmentation, which is considered as an effective way for segmentation, but very hard to obtain by traditional methods. Similarly, every year companies spend millions of dollars on marketing research to understand what, how, and why of consumer behavior using traditional methods. However, social media tools enable companies to conduct researches more effectively and efficiently with less effort and cost because it is easier, and quicker to reach people and data online. Social media also creates another communication platform for the companies by offering the opportunity of online and viral campaigns to attract the attention of people, and win their hearts and minds. Additionally, social media provides an excellent opportunity to the users to exchange ideas, feelings and thoughts among themselves about various brands, providing an 
excellent way to increase brand awareness, recognition, and loyalty (Gunelius, 2011). Finally, the social media platforms offer one-to-one marketing and provide firms to be in contact with customers by individualizing their offers and communication activities better with this media.

Given the opportunities it provides, companies to analyze and understand this new generation digital world, and develop their social media marketing strategies well ahead in order to be successful in this new era. The starting step should be to understand who the users are, and how they behave. Classifying diverse user behaviors into meaningful categories of user types, according to the frequency of use, variety of use and content preferences are very important (Brandtzaeg, 2010). Therefore, several authors and companies have focused on the marketing implications of the social media and classification of the social media users. There are two approaches in this end; the Uses and Gratification Theory, and the Social Technographic Model. In order to understand the motives of using social media, most of the authors such as Dunne, Lawyor and Rowley (2010); Urista, Dong and Day (2009); Haridakis and Hanson (2009); Sheldon (2008); Barker (2009); Raache and Raache (2008) applied the Uses and Gratification Theory which is based on how same media messages may be used by different people for different aims to satisfy their psychological and social needs and achieve their goals (Katz, 1959). Another important research developed by the Forrester Research Company is Social Technographic Model. This model aims to group the social media users according to their social media usage frequency and preferences. This study was repeated in 14 different countries, not including Turkey.

Mainly Inspired by the Social Technographic Model, the primary objective of this study is to classify the users according to their usage preferences of social media activities; and determine their demographic affinities and content preferences. A secondary objective is to explore what are the motivations to be present and/ or actively use social media tools. 


\section{The Scope and Significance of the Study}

The scope of this study is limited to the Internet users in Turkey. Turkey is considered as one of the seven largest emerging market economies which is called as E7 and is expected to show higher positive growth on average until 2050 (Hawksworth and Tiwari, 2011). The envisaged positive and stable conditions in Turkey make it a very desirable and profitable market especially for multinational companies to make investments and for local firms to expand their business. Thus, it is important to conduct studies to understand the marketing landscape of Turkey, especially the social media landscape since one way to compete in today's business world is to have a presence in the social media world for companies and brands. Since the Internet and social media usage rates are high in Turkey, the social media has gained importance as a marketing tool. The country is placed at the top 5 countries that use social media effectively. The Internet penetration rate is about $41.6 \%$; more than 30 million people in the country including all demographic groups connect to the Internet (TUIK, 2010).

Understanding consumer behavior, preferences, culture, values and attitudes is the first step while making business in a country (Lewis and Housden, 1998). Companies should segment the consumers in order to form more specific, realistic and achievable strategies for each segment offline and online. Social Technographic Model was developed by Forrester Company and was applied in 14 countries to cluster the social media users according to their behavior and contribution in respective countries. Similarly, the TrendStream Company conducted a research social media in 16 countries to understand consumer motivations, behavior, and preferences in social media in each country. However, almost none of the researches conducted related to social media by the researchers and institutions included social media usage in Turkey. Culture influences the lifestyle, and the lifestyle influences the way people communicate and interact among themselves via new media technologies (Brandtzaeg, 2010). Therefore; it is not possible to generalize the results of the studies conducted in other countries and a comprehensive research is crucial and should be conducted in order to understand the social media usage in Turkey. Accordingly, this study will be the one of the pioneer in this area and shed light on the social media usage in Turkey and cluster analyze the 
social media users to group them into meaningful segments. The results of the research are believed to help marketers to create more effective segmentation and one to one marketing opportunities on social media. On the other hand, academics in Turkey may take this study as a starting point to reveal the different features of the social media usage groups and to express the how the characteristic specifications of these groups change in time.

This study consists of four main parts. The first part is the literature review which is composed of five sections. The first section is about the web 1.0, 2.0 and 3.0 technologies and differences between these technologies. The second section is about the definition of social media and its types which are social networking sites, content communities, forums, virtual worlds, blogs or social news and bookmarking sites. In the third section the effects of social media on marketing is explained. In the fourth section, the previous studies about the user typologies of social media and motivations to its use are expressed. In the fifth section, The Internet and social media usage in Turkey is discussed.

Following the literature review, the second part consists of research objectives, questionnaire design, sampling and data collection. An exploratory and a descriptive research take place in this study to meet the research objectives. In the exploratory research, in-depth Interview method which was guided by semi-structured questionnaire used to enrich the scope of the questionnaire. Then, the likert type questionnaire is formed based on the literature and the exploratory research. In the descriptive research, total 1105 respondents were conducted the survey considering the $95 \%$ level of confidence and $3 \%$ confidence interval, and 1001 usable questionnaire were collected. In the findings part which is the third part, the data was tested with cluster analysis, factor analysis, ANOVA, chi-square, and scheffe tests using SPSS version 17.0 and the results are shown. The last part is the conclusion which is consisted of the comparison between the literature and research findings, implications for the marketers and the researchers, Limitations of the study and further research prepositions. 


\section{WEB TECHNOLOGIES}

On Wikipedia, the Internet is defined as "A global system of interconnected computer networks that use the standard Internet Protocol Suite (TCP/IP) to serve billions of users throughout the world. It is a network of networks that consists of millions of private, public, academic, business, and government networks, of local to global scope, that are linked by a broad array of electronic, wireless and optical networking technologies". The Internet has revolutionized the computer and communications, world is like nothing before (Leiner at al., 2009).

The Internet, which is one of the most important innovations for the human being, is not a static technology. It has improved and developed gradually and provided people brand new capabilities over the Internet. Although the lack of standardization of the Stages of the Internet (Singh, 2010) there are three eras of the Internet evolvement. Until now, there have been only two eras which are called Web 1.0 and Web 2.0, but the Web 3.0 era is expected to appear very soon (Bain, 2011). In this section, the definitions and differences of these eras will be mentioned.

\subsection{WEB 1.0 TECHNOLOGY}

Web 1.0 which is called read-only era is the Internet technology before the 1999 (Singh, 2010). O'Reilly (2005) defined Web 1.0 as a "set of static, one-way browser-based applications and Gillmor (2004) defined Web 1.0 sites which provide one way broadcast as Old Media. Web 1.0 was primarily one-directional, allowing plenty number of users to view the contents of a comparatively small number of sites (Goodchild, 2007).

Babaoglan (2007), who is a technology evangelist from Turkey, defined Web 1.0 as web sites consisting of HTML (Hyper Text Markup Language) infrastructure, are company based, just focusing on reading and supported by cable-net as well as Dial-up internet connections and covered by Netscape. In the Web 1.0 technology contents of the Internet sites were just determined by the site owners and users could just read these web pages (Guzelkan, 2010). In addition, users could only put the links of interesting web sites onto their personal web pages in Web 1.0 and so the links were not gathered 
in a portal to allow tag-based community (Kinsella at al., 2008). The technologic improvements which will be mentioned in the next section lead to a shift from Web 1.0 era to Web 2.0 Era.

\subsection{WEB 2.0 TECHNOLOGY}

Although there is no explicit differentiation between the Web 1.0 Era and Web 2.0 Era, 1999 is generally marked as the beginning of the Web 2.0 Era, which is called Read-Write-Publish Era, with remarkable contributions of LiveJournal (Launched in April, 1999) and Blogger (Launched in August, 1999) (Singh, 2010). Since the Internet technologies has being changed, new platforms and programming languages were created. And those changes enable web sites become more dynamic and faster. The delivery of Web 2.0 applications and services has been driven by the widespread adoption of one particular group of technologies which are called as AJAX (Asynchronous Javascript + XML) (Anderson, 2007).

JavaScript: The use of JavaScript has been growing steadily and CSS usage has been increasing even faster to make web sites more dynamic (Gibson, 2007).

XML (Extended Markup Language): XML technology enables storing the data, moving the data to other platforms and sharing the information and content easier (Gibson, 2007; Guzelkan, 2010).

Another technology that contributes the rise of Web 2.0 is high speed internet connection. Internet sites are embedding videos and sounds, as well as using Adobe Flash to create multimedia experiences which were enabled by High Speed Internet Connection (Gibson, 2007).

Web 2.0 concept first appeared in a conference's brainstorming session between Tim O'Reilly and MediaLive International. Dale Dougherty and O'Reilly pointed out that web platform was getting more and more important, In addition, thrilling new applications and popping up innovative web sites. They thought that this could be a turning point for the web and they agreed to call it as Web 2.0 and this is 
how this term was born (O'Reilly, 2007). Later this term was proposed to be separated into various versions of the Web as a new version of the Internet (Scholz, 2008).

After being created, Web 2.0 was defined by several authors with different definitions. Web Pioneer and founder of this concept, Tim O'Reilly (2007, p:1) defined that "Web 2.0 is the network as platform, spanning all connected devices; Web 2.0 applications are delivering software as a continually-updated service that gets better the more people use it, consuming and remixing data from multiple sources, including individual users, while providing their own data and services in a form that allows remixing by others, creating network effects through an 'architecture of participation,' and deliver rich user experiences". Additionally, McLoughlin and Lee (2007) defined Web 2.0 as a "Second generation, or more personalized, communicative form of the World Wide Web that emphasizes active participation, connectivity, collaboration and sharing of knowledge and ideas among users". Moreover, Web 2.0 has been covering the combination of innovations on the Web in recent years (Carmode and Krishnamurthy, 2008)

In literature there are several definitions of the characteristics of Web 2.0 technologies. Although being used different words in the definitions, the core of the meanings is approximately the same. (Aharony, 2008; O'Reilly, 2005; Zhang at al., 2008; Prilla and Ritterskamp, 2008). In the light of these authors' definitions, the characteristics of the Web 2.0 technologies are as following;

- Individual Production and User Generated content (UGC) means personal publishing and self-expression that enable users to contribute and control the Data on the Internet.

- Another characteristic is openness by means of providing open source software and working in a spirit of open innovation.

- Third characteristic is utilizing collective intelligence

- $\quad$ Forth characteristic is providing network-enabled interactive services that improve and facilitate user participation.

- $\quad$ Finally, immediate feedback that users and companies give or receive immediate responses. 
- $\quad$ The last but not least characteristic is usage simplicity

\subsection{MAIN DIFFERENCES BETWEEN WEB 1.0 AND WEB 2.0}

After the Web 2.0 term was defined by O'Reilly, It was very hard to categorize the web sites as Web 1.0 or Web 2.0. Because, today some Web 1.0 sites have dynamic structure and provide new features without the user participation. However, a clear separation is possible for the popular and innovative web 2.0 sites such as Facebook, Twitter and Youtube. On the other hand, determining the Amazon.com whether it is a Web 1.0 or Web 2.0 is very hard. The reason for this is that the users started to submit reviews and ratings which added value to the Amazon.com even though it was found in 1990's with an old logic (Carmode and Krishnamurthy, 2008).

Zhang at al. (2008) point out the main differences of Web 1.0 and Web 2.0 technologies as it is shown in Table-1.

Table 1: Differences between Web 1.0 and Web 2.0 Technologies

\begin{tabular}{|l|l|l|}
\hline & \multicolumn{1}{|c|}{ Web 1.0 } & \multicolumn{1}{c|}{ Web 2.0 } \\
\hline Technology & Hyperlink (Web HTML) & Social Web (XML) \\
\hline Time & $1994-2004[71]$ & 2004-Today \\
\hline Conception & Web as a medium & Web as a platform, software as a service \\
\hline Information & Read only & Read and Write \\
& Receive information passively & Create and receive information actively \\
\hline Communication & User-to-computer & Computer-to-computer and user-to-user \\
\hline Information discovery & Search and Browse & Publish and Subscribe \\
\hline
\end{tabular}

Source: Zhang at al., 2008 
- As it is mentioned above Web 1.0 consists of HTML which is a static structure, whereas Web 2.0 contains XML and Javascipt (Gibson, 2007).

- $\quad$ Before the Web 2.0 concept first appeared in 2004-2005, most web sites had Web 1.0 technology and Static Structure.(Zhang at al, 2008). After the year 2004 plenty of web sites have changed their structure and shifted to the Web 2.0 Technology (Carmode and Krishnamurthy, 2008).

- Web 1.0 was just considered as a medium, while web 2.0 considered as a platform and provides services through Web (O'Reilly, 2007).

- In the Web 1.0 users generally just read the web sites and get information so it is called Read Web, but Web 2.0 is called read and write web that enables users to contribute and share their knowledge and expressions (Habib, 2006).

- The nature of web 2.0 is collaborative and social in which there is peer to peer communication, but that is not possible in web 1.0 (Zhang at al., 2008).

- In order to get information users made search and browsed in web 1.0. However, in web 2.0 with the effect of user's contribution and data sharing, users get information by Publishing and subscribing (Zhang at al., 2008).

\subsection{THROUGH THE SEMANTIC WEB: WEB 3.0}

Cankaya (2007) who is the marketing manager of Microsoft Turkey claims that Web 1.0 is a world of static internet applications created by human; on the other hand Web 2.0 is a world of internet applications that can be changed and under the control of people. Web 3.0 concept will be a new world where the devices will interact among themselves and make the necessary controls. Although there is no standard definition of Web 3.0, Suphakorntanakit (2008, p:1) defines Web 3.0 as "Linking the devices to generate new approaches of connecting to the web by several machines and exchanging data among machines." Semantic Web will suppose to be the major actor of Web 3.0 Technology. Semantic web term was first defined by Tim-Barners Lee, who is the inventor of the World Wide Web. "Semantic Web is a place where machines can read Web pages as much as we humans read them, a place where search engines and software agents can better troll the Net and find what we're looking for" (Metz, 2007 $\mathrm{p}: 1)$. 
Funk (2009) claims that five trends and technologies will pioneer the Web 3.0; they are; The Semantic Web and Artificial Intelligence, Cloud computing, Universal, portable, and online identities, 3-D internet, True convergence of web, mobile devices, and other equipments.

It is still not reached at Web 3.0 Era. Therefore, almost all the comments about the Web 3.0 are just composed of predictions. Today no one exactly knows what kind of applications; innovations and developments will the Web 3.0 technologies bring for people. However, probably Web 3.0 Era will come soon and we will be the witness of the emergence and the revolution of the Web 3.0 technologies. In the near future, it is expected for social media sites, which will be mentioned in the next section, get into new forms with the effect of semantic Web. 


\section{SOCIAL MEDIA}

During the Web 2.0 Era, web site applications and infrastructures, Internet usage rate, Internet speed have developed gradually, and all these developments have formed a new world and created some opportunities both for people and corporations related to social relationships and business practices. One of the most important terms emerged through all these developments, is social media.

In the literature, some authors use the Web 2.0 and Social Media terms interchangeably, whereas other authors define these terms differently and express the differences of these terms. Social Media can be defined as web sites that are formed based on Web 2.0 technologies' infrastructure (Akar, 2010). Namely, Web 2.0 is defined by expressing technologic dimension; on the other hand, Social media is defined by considering the social dimension.

In this section, definitions, types and the history of the Social media will be presented.

\subsection{DEFINITION OF SOCIAL MEDIA}

In the literature there is not a standard definition of social media. Academics, Internet experts and consultants make their own definition of social media. Weber (2007, s.4) defines Social Media as "The social Media is the online place where people with a common interest can gather to share thoughts, comments, and opinions". According to Robinson (2007), social media is the tools used for communication that have Web 2.0 attributes that is, they are participatory, collaborative, knowledge sharing, user-empowering tools available on the Web. Safko and Brake (2009, s.6) define social media as "activities, practices, and behaviors among communities of people who gather online to share information, knowledge, and opinions using conversational media".

As it is seen in the definitions there are some common points between them. The first common point is sharing: in social media sites people may share their knowledge, comments, videos and photos. The second point is communication: people and companies communicate with their friends or customers, family members or 
employees, experts or new people. In this aspect, online word of mouth concept gain importance. The differences between online and offline word of mouth is reach count and speed. Mangold and Faulds (2007, p.4) points out that "Conventional marketing wisdom has long held that a dissatisfied customer tells ten people, however that is out of date, in the new age of social media, one has the tools to tell 10 millions of people'”

\subsection{TYPES OF SOCIAL MEDIA}

Social Media concept consists of a wide range of tools and platforms. The most important and common used social media types are Social Networking Sites, Content Communities, Virtual Worlds, Blogs, Microblogging Sites, Online Gaming Sites, Social Bookmarking and News Sites, Forums. These concepts will be explained in details with the aspects of definition, history and elements.

\subsubsection{Social Networking Sites}

Social networking is an increasing phenomenon related to the Internet, and several studies have been conducted about social networking sites. Although there are various definitions concerning social networking by distinguished scholars (Raacke and Bonds-Raacke, 2008; Dunne and Others, 2010; Constantinides,2009; Zarella, 2010), two of the most common definitions have been used in this study.

Social Networking Sites are "web-based services that allow individuals to (1) construct a public or semipublic profile within a bounded system, (2) articulate a list of other users with whom they share a connection, and (3) view and traverse their list of connections and those made by others within the system." (Boyd \& Ellison, 2008)"'. In addition Kaplan (2010) defines social networking sites as "Social networking sites are applications that enable users to connect by creating personal information profiles, inviting friends and colleagues to have access to those profiles, and sending e-mails and instant messages between each other. These personal profiles can include any type of information, including photos, video, audio files, and blogs".

Kaplan (2010) claimed that the first social networking site which was called “Open Diary" was founded by Bruce and Susan Abelson 20 years ago. In 1995, 
Classmates.com, which enables people to find their old school friends, and Match.com, which is an online dating site, were created; both remain fairly popular sites in their niche (Zarella, 2010). In 1997, www.sixdegrees.com which is in very similar form with current social networking sites that users could create their profiles and list their friends. Between the years 1997 -2001 several social networking sites such as AsianAvenue, blackPlanet and miGente appeared. In 2001, ryze.com was launched, but this social networking site was just for the business networks (Boyd and Ellison, 2007).

The growing availability of high-speed Internet access further added to the popularity of the concept, leading to the creation of social networking sites (Kaplan and Haenlein, 2010). In 2002, the modern era of social networks began, when Jonathan Abrams launched Friendster, inspired by Match.com (Zarella, 2010), and which was designed to help friends of friends meet (Boyd and Ellison, 2007). In 2003, Myspace was launched by duplication of Friendster's functionality and added some new features such as customizable user profile and mostly focused on music applications. In a short time MySpace became one of the best social networking site (Zarella, 2010). Since Myspace's popularity increased rapidly in 2005 Rupert Murdoch's media conglomerate News Corp purchased MySpace the amount of $\$ 580$ million (Mintz, 2006). Today, MySpace is the 22th most clicked website in the world (Alexa.com). Although there is no certain information about number of total registered users, in his Internet site Elkin (2007) claimed that MySpace has over 185 million users.

Subsequently in 2004, Facebook which is a social utility that helps people communicate more efficiently with their friends, family and coworkers was founded by Mark Zuckerberg in 2004. (Facebook.com). However, previously users had to have a harvard.edu email address in order to join Facebook. One year later Facebook expanded to include high school students, professionals inside corporate networks (Boyd and Ellison, 2007). Eventually in 2006, everybody could join to facebook with an e-mail address (Zarella, 2010). Today, Facebook is the second most clicked web site in the world among all types of Internet sites comes after the google (Alexa.com). According to Facebook's own statistics (2010), on facebook there are more than 400 million active 
users, every user on average has 130 friends, people spend over 500 billion minutes per month.

Boyd and Ellison (2007) claimed that while MySpace attracted the majority of media attention in the U.S. and abroad, Social Networking sites started to getting more popular globally such as Orkut in Brazil, Friendster in Pacific Islands, Mixi in Japan, Lunarstorm in Sweden, Grono in Poland, Hi5 in Latin America and Bebo in United Kingdom, New Zealand and Australia (Boyd and Ellison, 2007).

Social networking sites differentiate themselves from all other types of social media. Because, most of the social networking sites include all other social media sites' tools, features and applications in their own platform. For instance in a social networking site, a user can create a profile, send private message, upload photos and videos, watch videos, play games, join a social group, arrange an event and use several applications. Zarella (2010), summarize the elements of social networking sites as below.

Profile: Individuals and Companies can create a Profile on Social Networking Sites. This information can be about personal, educational, employment and interests.

Connecting: Two or more people can connect which is one of the most important feature through social networking sites.

Private Messaging: Users can send private or group messages via Social networking sites

Public Messaging: Public messages are called comments in MySpace and wall messages in Facebook. Comments can be made to profiles, photos, videos, events, groups and company pages.

Groups: Most social networks contain the concept of a group which consist of the users who have similar interests and they can share and discuss the contents. 
Photos and Videos: Sharing photo and video are two of the most popular features of social networking sites. For Example, Facebook's photo-sharing feature is more popular than all of the other photo-sharing sites.

Events: Most social networks will allow you to create an event and invite your friends to attend it. These events most commonly occur in the real world

Applications: Social networks have exposed their functionality through application programming interfaces (APIs) to developers, allowing them to create applications that plug into their site.

\subsubsection{Content Communities:}

With the advent of easy-to-use digital cameras and camcorders as well as highspeed Internet connections, media-sharing sites have become extremely popular (Zarella, 2010). The main objective of content communities is the sharing of media content between users. Content communities exist for a wide range of different media types, including text, photos, videos, music (Kaplan and Haenlein, 2010).

One of the earliest Content Community Site, IFILM.net, was launched in 1997 as an online collection of short videos where users could also submit their own work. In 1999, Ofoto, Shutterfly and webshots which were photo sharing and uploading sites were founded. In 2002, Flash MX was released and this tool enabled users to watch videos without downloading a special player. However content communities became more popular after Flicker's launch in 2004. (Zarella, 2010). Flickr is one of the best online photo management and sharing application in the world. Two main purpose of Flickr is helping people to make their content available for other people who matter to them. The second purpose is providing new ways for organizing photos. (Flicker.com). Now there are approximately 4 billion images in Flickr (trak.in)

The second revolution of content communities was the founding of YouTube which allows its users to post videos for public viewing and commentary. YouTube was founded in 2005 by PayPal employees Chad Hurley, Steve Chen, and Jawed Karim (Kelli, 2008). In a short time YouTube became the fastest growing Internet site ( Kelli, 
2008). On October 2006, YouTube was acquired by Google Company for 1.65 billion values (http://www.google.com/intl/en/press/pressrel/google_youtube.html). YouTube allows people to upload their own videos and watch others' videos, the YouTube database contains numerous videos on any topic (Mabry, 2010). In Addition, YouTube provides a forum for people to connect, inform, and inspire others across the globe and acts as a distribution platform for original content creators and advertisers large and small (YOUTUBE, 2010). Today, YouTube is the $3^{\text {th }}$ most clicked web site in the world (ALEXA, 2010).

\subsubsection{Forums:}

Forums are the interactive sites that the users share their knowledge and ideas with other people who have similar interests (Constantinides, 2009). In his book Zarella (2010) claimed that Forums are the oldest type of social media and modern form of community bulletin boards. In forum sites the focus is on the discussion. Users post what they know or wonder and other users reply them or make comments to them. Thus, a knowledge database has being created which took millions of internet users many years. Although forums are very convenient information sources, completely relying on forum sites may not be good solutions. Because, most of the forum sites are generated automatically and their contents was formed by amateur users (Xu and Ma, 2006).

\subsubsection{Virtual Worlds}

Virtual worlds are platforms that replicate a three dimensional environment in which users can appear in the form of personalized avatars and interact with each other as they would in real life (Kaplan and Haenlein, 2009). Today, there are millions of users in Virtual worlds and this number is increasing day by day (Tikkanen at al., 2009). Kaplan and Haenlein (2009 p: 64) claimed that virtual worlds are probably the ultimate manifestation of Social Media, as they provide the highest level of social presence and media richness of all applications discussed thus far. 
Kaplan and Haenlein (2009), Tikkanen and others (2009) and Zarella (2010) categorize virtual worlds into two. First category is social oriented virtual worlds and the second one is game oriented social worlds.

\subsubsection{Virtual Game Worlds}

The virtual worlds games include similar elements of traditional video games and their purposes to reach higher levels by gaining extra points (Tikkanen at al, 2009), and require their users have to obey the strict rules in the context of a massively multiplayer online role-playing game (Kaplan and Haenlein, 2009). One of the most popular virtual world game is "World of Warcaft" (Zarella, 2010) and 8.5 million subscribers or the game who explore the virtual planet of Azeroth in the form of humans, dwarves, orcs, or night elves, to fight monsters or to search for treasure (Kaplan and Haenlein, 2009 p:64).

\subsubsection{Virtual Social Worlds}

The second group of virtual worlds is the virtual social world which allows inhabitants to choose their behavior more freely and essentially live a virtual life similar to their real life (Kaplan and Haenlein, 2009). In addition advanced subscribers can create objects and places (Zarella, 2010). In social worlds, users don't have certain goals. Since there is an interaction and networking with other users, virtual social worlds are similar to the Social networking sites (Tikkanen at al., 2009).

\subsubsection{Blogs}

In literature, Blog is defined by several authors (Zarella, 2010; Kelli, 2008; Huffman, 2008; Kaplan, 2007; Weber, 2008). One of the most comprehensive definition of blog is "Blogs are personal web sites written by somebody who is passionate about a topic, provide a means to share that passion with the world and to foster an active community of readers who provide comments on the author's posts.(Scott, 2010, s. 37)

One of the first blog which was about the video games and gaming conventions was created by Justin Hall in the mid-1990's (Zarella, 2010). In 1997, the term weblog which is combination of the words web and log was created by Jorn Barger and in time 
it has started to called as Blog (Aschenbrenner and Miksch, 2005). Blogging started to became popular when LiveJournal and Blogger were launched (Zarella, 2010). This opened Blogs to larger audience (Aschenbrenner and Miksch, 2005). Today, the exact total number of Blogs is not known, but it is estimated to be around 150 million and Globally approximately 350 million people read blogs (Thefuturebuzz.com, 2010)

\subsubsection{Microblogs}

Microblogging is a new form of communication in which users can describe their current status in short posts distributed by instant messages, mobile phones, email or the Web (Java and Others, 2007, s.1). In 2004, micro blogging term appeared when a group of technologists and activists created TXTmob that allow people to communicate through short text messages (Zarella, 2010).

However Micro-Blogging became popular after the launch of Twitter in 2006. On Twitter subscribers update their status and share information about their activities and opinions which is limited only 140 characters (Java and Others, 2007). Twitter rapidly growth in 2009 as a result of well-known celebrity members and a mention on Oprah (Zarella, 2010). Today, according to the Alexa.com Twitter is the $11^{\text {th }}$ most visited web site in the world. Twitter is one of the most effective tool in social media marketing. Zarella (2010, s.31) claimed that "Most companies should be on Twitter; it's easy, requires very little investment of time, and can quickly prove worthwhile in increased buzz, sales, and consumer insight”. In addition Twitter can be used in order to announce offers, events and promotions.

\subsubsection{Social News Sites and Bookmarking}

Zarella (2010, s.103) defines social new sites as "Social news sites are websites that allow users to submit and vote on content from around the Web". People vote the news and it became very easy to differentiate interesting and useful links from the others.

"Social bookmarking sites are similar to social news sites, but the value presented to users is focused on allowing them to collect and store interesting links 
they've found and may wish to revisit" (Zarella, 2010, p.103). Companies can track the number of people who are bookmarking you page and can understand how remarkable their format message is. If nobody bookmarks a web site, they have to reconsider about their content (Halligan and Shah, 2010)

ITList was the first social bookmarking site which was launched in April 1996, and from that point until the pop of the first dot-com bubble, a plethora of sites offering public and private online storage of your favorite links emerged (Zarella, 2010). Today, Digg which was launched in 2004 is the most popular social news sites. "Digg allows users to submit and moderate their stories by voting on them" (Lerman, 2007, p.1). On the other hand Delicious (Del.icio.us) is one of the most popular social bookmarking sites. Delicious which is belong to Yahoo group, boasts more than 5 million users and more than 150 million URL's (Weinberg, 2009). Users can put their favorite links onto their own web pages within delicious domain. In addition, Delicious offers a search function that provides users to search their own bookmarks (Barsky and Purdon, 2006). 


\section{SOCIAL MEDIA AS A MARKETING TOOL}

Social media have impacts on several functions for the businesses. One of the most important departments which can derive benefit from the Social Media is marketing. Because, Social Media provides an effective way to attain and engage in present and potential customers (Halligan and Shah, 2010) and also it encourages interaction between consumers and brands (Tuten, 2008). Joaker (2009, p.12) defined social media marketing as "an interaction with a set of online social media conversations from marketing perspective, based on converged media (since conversations can span both technologies and the media)". In addition Social Media Marketing is defined by Weinberg $(2009$, p:3) as "Social media marketing is a process that empowers individuals to promote their websites, products, or services through online social channels and to communicate with and tap into a much larger community that may not have been available via traditional advertising channels". Social-media marketing is a form of online advertising that consists of social networking sites, virtual worlds, social news sites and social opinion-sharing sites in order to meet branding and communication objectives (Tuten, 2008).

Social media marketing has formed its own niche in the business world. Firms are hiring social media experts and consultants; and these companies are forming the social media marketing department which is different from the traditional marketing departments (Coon, 2010). In his Social Media Webinar, Fouts (2010) suggests that while assigning new personnel who will be responsible from social media marketing, the company must recruit a person who is experienced in online world, experience in all aspects of marketing, politics and cooperation. In addition, the company is expected not to put stern rules since social media world is different from others. Instead, the company should provide just guidance.

The rules of the business have changed in the social Media era radically, and now customers claim more honest and direct relationship with the companies. 
Gordhamer (2009) defines four main shifts in the business world caused by social media;

- From "Trying to Sell" to "Making Connections": The forth era in the history of marketing is "Relationship Era" which emerged in 1990's. In this Era, companies trying to build long- term, value-added relationships with customers (Kurtz, 2008). By using social media tools companies may easily interact with their customers. The most popular companies in social media post contents less about their services and products, more about the information about the company and whereby such engagement customers feel more comfortable doing business with these companies (Gordhamer, 2009).

- From "Large Campaigns" to "Small Acts": In Today's business world, companies realized that small campaigns can be more valuable than the large traditional campaigns in which are spent millions of dollars (Gordhamer, 2009). Since sharing and communication is far easier with social media, some small campaigns can reach lots of people and accomplish the objectives (Coon, 2010). For example, Burger King announced a campaign named "Whopper Sacrifice" that if a Facebook user deletes 10 friends from his friend list; the user will get a free whopper menu coupon. The budget of the campaign was very limited but the effect of the campaign was great (McCarty, 2009). 83.000 people used the application and approximately 230.000 friends were deleted to get free coupon in just 9 days (D'souza, 2009).

- $\quad$ From "Controlling Our Image" to "Being Ourselves": Gordhamer (2009) claims that the companies that try to be themselves instead of manipulating their image are more successful in online World. In addition to, these companies should give more freedom to its employees while they are managing social media accounts. That will enhance the idea that the company is as if a human and also if the users see negative contents about the company on the sites that the sites may seem more real and believable to the users (Coon, 2010).

- From "Hard to Reach" to "Available Everywhere": Today, customers are more powerful and busy that they don't want to wait for hours on the phone or receive e-mails. Therefore, just to provide a contact number and e-mail to the customers is not 
sufficient for the companies. The companies should be able to be reached in any communication channel such as Facebook, Twitter, Blogs, Forums( Gordhamer (2009).

In addition to the Gordhamer's suggestions; Weber (2007) claims that in order to be successful in the social Media, marketer's should first change their marketing mindset from the Old Marketing to the New Marketing which is called Social Media Marketing and then change the approach to the other components of the marketing. Table-2 shows the comparison of the approaches of the old and new marketing (Weber, 2007 p: 33-34).

Table 2: The Comparison of Old and New Marketing

\begin{tabular}{|c|c|c|}
\hline Components & Old Marketing & $\begin{array}{c}\text { New Marketing / } \\
\text { Social Media Marketing }\end{array}$ \\
\hline $\begin{array}{l}\text { Marketing } \\
\text { mindset }\end{array}$ & $\begin{array}{l}\text { Use one-way, one-sided } \\
\text { communication to tell } \\
\text { brand story. }\end{array}$ & $\begin{array}{l}\text { Nurture dialogue and relationships; be more } \\
\text { transparent, earn trust, build credibility. }\end{array}$ \\
\hline Brand equity & Brand recall is holy grail. & $\begin{array}{l}\text { Brand value is determined by customers: } \\
\text { How likely are customers to highly } \\
\text { recommend the good or service? }\end{array}$ \\
\hline Segmentation & $\begin{array}{l}\text { Group customers by } \\
\text { demographics. }\end{array}$ & $\begin{array}{l}\text { Group customers by behavior, attitudes, and } \\
\text { interests - what is important for them. }\end{array}$ \\
\hline Targeting & $\begin{array}{l}\text { Target by demographics, } \\
\text { especially for media } \\
\text { buying. }\end{array}$ & Target according to customer behavior . \\
\hline Communication & $\begin{array}{l}\text { Broadcast style: create and } \\
\text { push message out for } \\
\text { customers to absorb. }\end{array}$ & $\begin{array}{l}\text { Digital environment for interactive } \\
\text { communication through search and query, } \\
\text { customer comments, personal reviews, or } \\
\text { dialogue. }\end{array}$ \\
\hline Content & $\begin{array}{l}\text { Professional content } \\
\text { created and controlled by }\end{array}$ & Mix of professional and user-generated \\
\hline
\end{tabular}




\begin{tabular}{|c|c|c|}
\hline & marketers. & content, increasingly visual. \\
\hline Virality & $\begin{array}{l}\text { A nice feature but } \\
\text { popularity too often driven } \\
\text { by flashy presentation } \\
\text { rather than content. }\end{array}$ & $\begin{array}{l}\text { Virality based on solid content about } \\
\text { remarkable products or features that will get } \\
\text { people talking and forwarding e-mail. }\end{array}$ \\
\hline Reviews & $\begin{array}{l}\text { Think Michelin Guide: the } \\
\text { experts weigh in. }\end{array}$ & $\begin{array}{l}\text { Think Amazon: users review and } \\
\text { vote on everything. }\end{array}$ \\
\hline $\begin{array}{l}\text { Advertiser / } \\
\text { Publisher Role }\end{array}$ & $\begin{array}{l}\text { Publisher establishes } \\
\text { channel and controls } \\
\text { content to gather an } \\
\text { audience for the advertisers } \\
\text { who sponsor channels or } \\
\text { programs. }\end{array}$ & $\begin{array}{l}\text { Build relationships by sponsoring (not } \\
\text { controlling) content and interaction when, } \\
\text { where, and how customers want it. }\end{array}$ \\
\hline Strategy & $\begin{array}{l}\text { Top-down strategy } \\
\text { imposed by senior } \\
\text { management drives tactics. }\end{array}$ & $\begin{array}{l}\text { Bottom-up strategy builds on winning ideas } \\
\text { culled from constant testing and customer } \\
\text { input. }\end{array}$ \\
\hline Hierarchy & $\begin{array}{l}\text { Information is organized } \\
\text { into channels, folders, and } \\
\text { categories to suit } \\
\text { advertisers. }\end{array}$ & $\begin{array}{l}\text { Information is available on demand by } \\
\text { keyword, to suit users. }\end{array}$ \\
\hline Payment & $\begin{array}{l}\text { Cost per Thousand (CPM): } \\
\text { Emphasis on cost; } \\
\text { Advertisers buy with the } \\
\text { idea that share of voice = } \\
\text { Share of mind = Share of } \\
\text { market. }\end{array}$ & $\begin{array}{l}\text { Return on Investment (ROI): Invest in } \\
\text { marketing for future growth and profitability } \\
\text { based on measurable return }\end{array}$ \\
\hline
\end{tabular}

Source: Weber, 2007, p: 33-34 
The companies can reach some of their marketing goals by using Social Media Marketing, these marketing goals are (Tuten, 2008, p25-26);

- Build brand awareness

- Maximize cross and within-media integration

- Research consumer behavior

- Develop ideas for new marketing strategies

- Drive traffic to corporate Web sites

- Increase site stickiness, extending the brand message's exposure time

- Garner publicity from news coverage of social-media tactics

- Improve search engine rankings (due to organic links)

- Build awareness of the brand

- Enhance the brand's reputation and image

- Encourage message internalization

- Increase product sales

- Accomplish marketing goals with efficiency

- Engage consumers in a brand experience

Social Media can be used for different areas of marketing as given above. However, after detailed literature review it is possible to claim that the major marketing areas are Segmentation, Marketing Research, Promotion, Branding, Customer relationship Management (CRM) and e-WOM.

\subsection{SEGMENTATION}

In order to achieve the marketing goals, firms must define target groups that they will focus on, so the segmentation is one of the most fundamental of marketing (Frey and Rudloff, 2010). A market segment consists of a group of people who have similar needs and wants. Marketers cannot create these segments; they can only identify the existing segments. Segment marketing offers key benefits over mass marketing (Kotler, 2006). Since the markets are getting too divided; instead of traditional marketing techniques, one to one marketing is getting more important (Garnyte and Perez, 2009). Social Media categorizes people according to their demography, 
preferences and life-styles. Therefore, social media leads companies to segment the customers better and more effectively. In social media, people get together to share and discuss specific interests, so people are naturally segmented according to their needs, behaviors, interests and even opinions. In this context, social media does not create new market and segments just enable to identify them (Vaynerchuk, 2008). Although the traditional segmentation methods focus on demographic segmentation such as geographical, gender, age; in the social media consumers tend to group themselves by their interests and attitudes (Weber, 2007).

Social media enables companies to apply micro-segmentation or even one-toone marketing strategies especially in the context of advertising. Ad network tracking programs trace the online behavior of the users and demography of them. That behavior data later will be used to serve highly related advertisements to the micro-segmented users who are likely to be interested in the product and service. For example, if a Facebook user searches for a flight on Expedia.com, later on the user will be shown a display ad for Orbitz.com (Tuten, 2008).

\subsection{MARKETING RESEARCH}

Kotler and Keller (2006, p: 102) defined Marketing Research as "The systematic design, collection, analysis, and reporting of data and findings are relevant to a specific marketing situation facing the company". In addition, they claim that there are three affordable and creative ways for the companies to conduct a marketing research. These ways are checking out the rivals, engaging professors to design and carry out projects and the last one is using the Internet.

At the Internet, especially in social media people are commenting and mentioning about the companies. Cooke and Buckley (2007, p: 271-279) defined several trends which are the growth of the open source movement, the emergence of Web 2.0, the emergence social media landscape, the rapid growth of online social networks, the combination of social computing tools that enable marketing researchers to develop new approaches. That's why social media contributes to the companies as a revolutionary marketing research tool. Instead of expensive focus groups, field studies 
and experiments the more accurate and timely informative social media is ready for the companies for free (Eley and Tilley, 2009). The emergence of social media offers marketers an array of collaborative tools with which to develop new research approaches to explore the rapidly changing social and media environment (Cooke and Buckley, 2007). Companies and marketers can get instant feedback about their products, services, campaigns and competition from the customers such as "what they think" and "how they react"(Gunelius, 2011). For example, the marketing researchers may evaluate the companies, products and services by looking at the ratings, rankings, comments, reviews and responds related to them. (Cooke and Buckley, 2007).

Today, several companies use social media tools for marketing research in the context of netnography (Kaplan and Haenlein, 2010). Netnography, made up of internet and ethnography, is a "qualitative consumer research methodology that uses the information publicly available in online forums to identify and understand the needs and decision influences of relevant online consumer groups". It is argued that netnography is the most adequate method to examine customer experience because customers usually write their reviews after their stay ends, so their experience is not affected by observation (Kozinets, 2002). Ismail, Melewar and Woodside (2010, p.12) claimed that "Traditional ethnographic methods include; (1) gaining ,entréee into the culture or group one wants to investigate; (2) gathering and analysing data; (3) ensuring trustworthiness of data interpretation; (4) conducting ethical research; and (5) member checking, or getting feedback from participants".

\subsection{PROMOTION}

Today, social media tools have become a very important tool for the promotion activities. There are three main purposes for promotion; first, to increase product awareness, second to persuade people to purchase the product, or to remind people that the product exists (Kotler \& Keller, 2007). Mangold and Foulds (2009) claimed that social media should be considered as the sixth tool of the promotion mix. Companies may provide special discounts and opportunities to their members on their social media group pages in order to make them feel valued and special (Gunelius, 2011). For example, Onur Air announced that the first 50 users, who became a member on its 
Facebook page, will get free tickets. In addition, occasionally Onur Air makes about30 $\%-50 \%$ discounts to its Facebook members (ONURAIR, 2011).

Mangold and Foulds (2009) expressed two main roles of Social Media on Promotion. The first role is very similar to the traditional integrated marketing tools. Companies can talk to their customers via social media tools. The second role of the social media on promotion is unique. Customers can talk to each other via social media which is not possible in traditional media and companies cannot directly control the messages.

There several impacts of the interactions between customers. These Impacts are; (1) The Internet has became a mass media tool for consumer sponsored communications. (2) Consumers demand more control over their media that is why they prefer social media tools instead of traditional sources of advertising such as radio, television, magazines and newspapers. (3) Consumers are more likely to prefer using social media tools while searching information about the products and services, and decide to purchase (Vollmer \& Precourt, 2008). (4) The content on the social media is more trustable than the traditional media because the source is themselves (Weber, 2007).

In the Figure-1, Mangold and Foulds (2009) have developed a model for a new communication Paradigm;

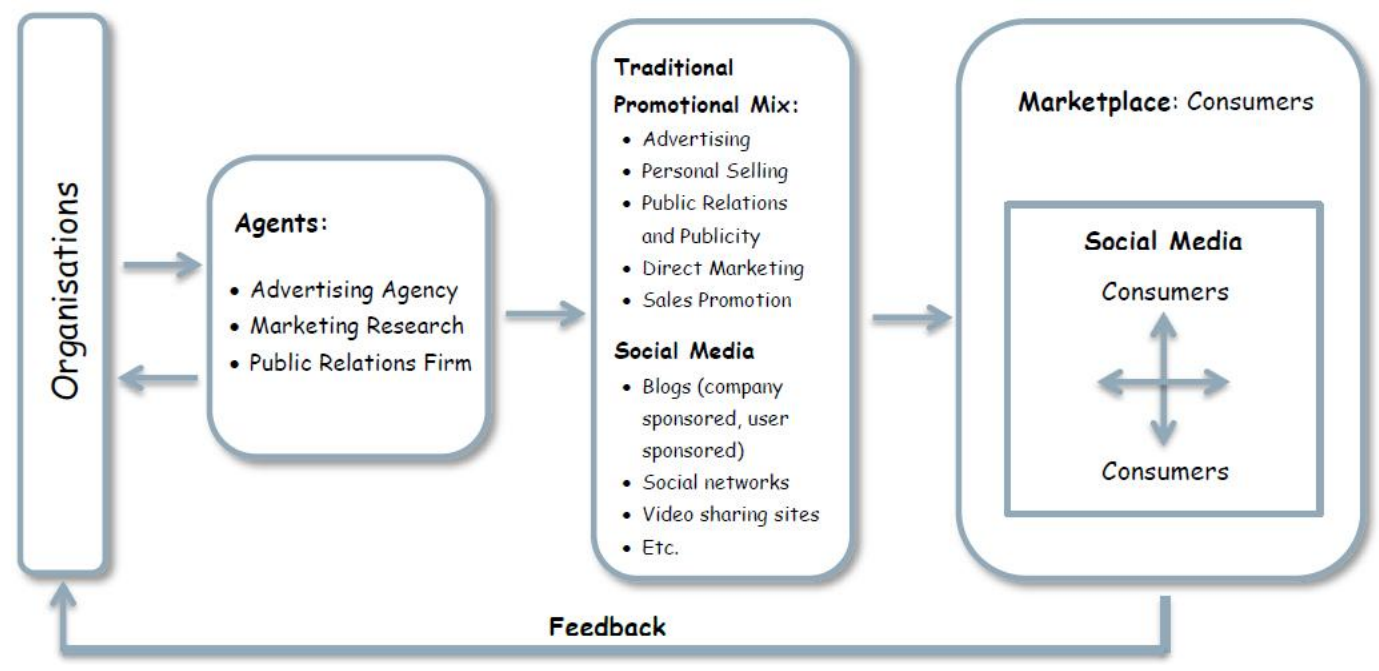

Figure 1: New Communication Paradigm

Source: Mangold and Foulds, 2009. 
Viral Marketing is the most common promotion tool in social media (Thackeray at al., 2008). Porter and Golan (2006, p. 33) defines Viral marketing as "unpaid peer-to-peer communication of provocative content originating from an identified sponsor using the Internet to persuade or influence an audience to pass along the content to others". Clifford and Marsh (2009, p. 51) claimed that "The key difference between a viral and a TV ad is that a viral is something you will seek out, take pleasure in finding, and send on for someone else to enjoy". Therefore it can be said that viral marketing has more impact on customers than mass media tools. For example, $78 \%$ of the consumers trust peer recommendations, whereas only $14 \%$ of them trust company's mass media advertisements (Quelman, 2010).

\subsection{CUSTOMER RELATIONSHIP MANAGEMENT}

The forth era in the history of marketing is the Relationship Era which has emerged since 1990's. In this Era the main objective of the marketers are establishing and maintaining long- term and value- added relationships with their customers and suppliers (Boone at al., 2009). Instead of one way communication in the Web 1.0, in social media, there is two-ways communication as it was mentioned in the previous sections. This two-ways communication which was enabled by social media provides several benefits for the companies to improve the relationship with their customers. One of the major benefits of social media marketing is the ability to create relationships with actively engaged consumers, online opinion leaders and peers (Gunelius, 2011). In social media marketing the customers are the core strategy just as in relationship marketing (Garnyte and Perez, 2009). In social media, the relation between a customer and Company will start mostly when the customer visit the company's website or read reviews and comments on a company's products or services (Scott, 2010). In order to have a strong relationship with the customers, companies must pay attention to make the members a part of their marketing message and have to take the customers' concerns and feedbacks into consideration and respond them. In addition, if the users have a good impression about the company, they recommend the company to its friends who are looking for products or services via online Word of Mouth (Weinberg, 2009). 
Weber (2007) claimed that there are two ways for the companies to create relationship with the several online customers through social media. These ways are;

- $\quad$ Participate in the conversations that users are having. On the social media customers have chance to look for information about products and services via online conversations and reviews. Companies should participate these conversations in order to establish reliable and open relationships with the customers.

- Provide compelling content and creating retail environments which customers want to visit.

\subsection{BRANDING}

According to the American Marketing Association, a brand is a "name, term, sign, symbol or a combination of them, intended to identify the goods and services of one seller or group of sellers and to differentiate them from those of competition" (Keller, 2007). Since, Social Media enable users to share information with their peers about the product and service brands (Stileman, 2009), the conversations between the peers provide companies an excellent way to increase brand awareness, boost brand recognition and recall, and increase brand loyalty (Gunelius, 2011). Weber (2007) claimed that Social Media is a dialogue between the company and customers; if the dialogue is strong, then the brand will be strong, or vice-versa is valid as well. Because the users determine the index of the contents on social media, that means brands will no longer control the contents. Therefore social media is a both opportunity and threat for the brands (Stileman, 2009). In the previous sections it was mentioned about why social media is an opportunity for the companies. On the other hand, some companies may be suffered by social media such as Dell Company. Jeff Jarvis has one of the most respected blog about internet and media. He bought a Dell notebook, but it has some problems. When the service fix it, each time it had another problem. He could not reach the responsible. And he posted his blog “'DELL SUCKS, DELL LIES”. In a short time, thousands of people began to rally around him and his blog became a platform to complain about Dell Company. Just in while, these complains appeared in front of the Dell homepage on Google search and began to damage Dell's brand. Dell's share price quickly decreased, the revenue fell and customer satisfaction ratings dropped. Dell 
admited they had problems, but were trying to fix them. Finally, Dell responded to this in the best possible way, they began replying blog posts and even set up their own blog (Stileman, 2009).

McKee (2010) developed a model which is called "The social Trinity Model" that different social media tools that are used for branding presented on three dimensions based on their aims. The Social Trinity Model is given in Figure-2;

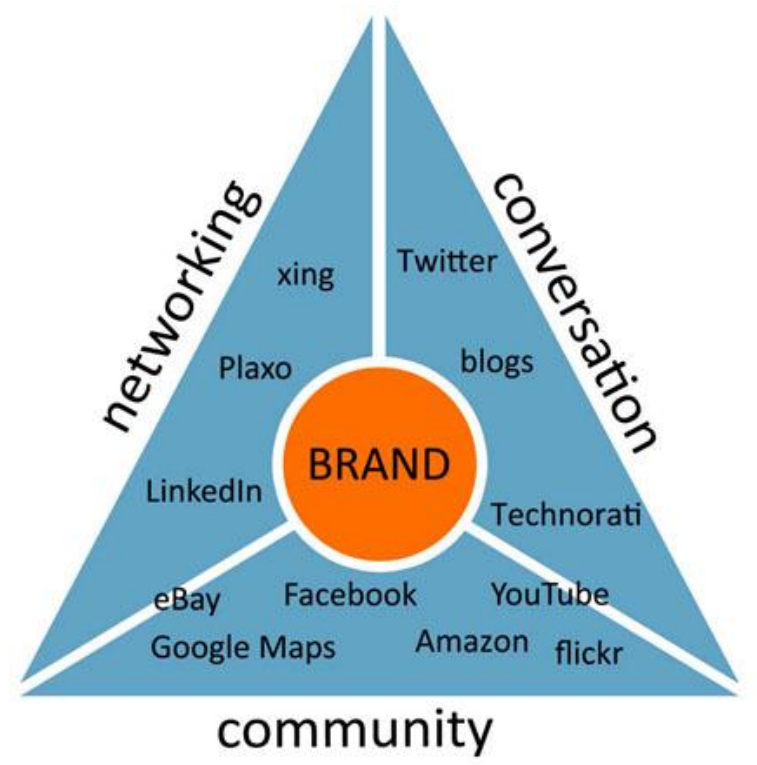

Figure 2: The Social Trinity Model

Source: McKee, 2010, p:183.

Conversation: In the conversation dimension, people are sharing their opinions and views about the brands via social media tools and this conversation may build first interest and later on loyalty for the brands (McKee, 2010).

- Community: In the community dimension, users create communities and these communities enable customers an informal and unrestrictive environment to join a participative dialog about the brands (McKee, 2010).

- Networking: In the networking sites, people in the business world connect with other business professionals to keep in touch. They may share the information about the industries, competitors and also they may evaluate brands and make comments on them (McKee, 2010) 


\section{SOCIAL MEDIA USER TYPOLOGY}

Year by year, more people prefer to use social media tools. In addition the number and variety of social media sites have increased gradually. Considering these increases in the Social Media Landscape, it is important to classify the users according to their variety of use, content preferences and frequency of use (Brandtzaeg, 2010). In this study it will be mostly focused on the Uses and Gratification Theory and Social Technographics Model. Therefore, the motives of using social media and social media users' typology will be understood better.

\subsection{USES AND GRATIFICATIONS THEORY}

Uses and Gratifications Theory explains how same media messages may be used by different people for different aims to satisfy their psychological and social needs and achieve their goals (Katz, 1959). In addition Rubin (1994, p: 419) defines Uses and Gratification Perspective as "People's needs and motives to communicate, the psychological and social environment, the mass media, functional alternatives to media use, communication behavior, and the consequences of such behavior". In the past, this theory applied to Mass media tools and media content. (Dunne, Lawyor and Rowley, 2010). In 1996, Newhagen and Rafaeli suggested that Uses and Gratification Theory might well be suited to online media tools. Later on various authors applied this theory to analyze the motives of using Internet and other social media tools.

For instance; Dunne, Lawyor and Rowley (2010) applied this theory for the motives of social networking sites and the results were Communication, Friending, Entertainment, Escapism and Information search. Urista, Dong and Day (2009) found out why young adults use social networking sites according to U\&G Theory. The results were efficient communication, convenient communication, Curiosity about others, Popularity, Relationship formation and reinforcement. Haridakis and Hanson (2009) applied Uses and Gratification Theory to find out the motives to watch online videos, and the results were participants watch videos for information seeking, and viewed and shared videos for entertainment, co-viewing and social interaction. 
In addition, some studies which are aimed to find out the motives of using social media tools Gender as a mediating variable based on Uses and Gratification Theory; For example, Sheldon (2008) researched on the motives for using Social Networking Sites. According to the Study, women were more likely to go to social networking sites to maintain existing relationships, pass time and be entertained. Per contra, men were more likely to go to Facebook to develop new relationships or meet new people. Barker (2009) also focused on a similar study and found out that females prefer to use social networking sites in order to communicate with peers, Pass time, Entertainment, while males prefer social networking sites for Social Compensation, Learning and Social Identity Gratification.

Raache and Raache (2008) conducted a detailed research in order to understand why people use social networking sites via U\&G Theory. Results were to keep in touch with old friends, to keep in touch with current friends, to post/look at pictures, to make new friends and to locate old friends. Less commonly reported uses and gratifications included to learn about events, to post social functions, to feel connected, to share information about yourself for academic purposes and for dating purposes.

Besides these academic studies, some consultancy firms applied very detailed and comprehensive studies in order to find out the motives of using social media. One of these companies is TrendsStream. They applied a-30-minute-survey to total 32.000 users in 16 different countries throughout the world. The results that show the motives of using social media are research on products and how to do things stay up to date on news, stay in touch with friends, research for work, entertainment, education, to get inspired, keep the friends up to date with the life and fill up spare time. Another study was conducted by Elife Company (2009) to explore the use and behavioral habits of Brazilian internet users in social media. According to the study the major motives to use social media are reading news, searching for information, maintaining the contact with the friends, getting information on leisure and entertainment, meeting new people, having fun as a pass time, researching on products and companies, 


\subsection{SOCIAL TECHNOGRAPHIC MODEL}

Social Technographics model is created by Li, Bernoff, Fiorentino and Glass (2007) who work for the Forrester research company. The term Social Technographics is used "to describe the different ways in which consumers may behave online, which in turn governs how they will respond to approaches from companies via social networking channels."'(Harris and Rae, 2009, p.30). Social Technographics is a tool that marketers should consider before creating their strategies (Li and Others, 2007). With this model companies will easily understand which customers use which types of social media and create a strategy in order to communicate with them efficiently (Harris and Rae, 2009).

In this model, social media usage behaviors are categorized into a ladder with six level of participation and each level has its own characteristics ( $\mathrm{Li}$ at al. 2007). These levels are Creators, Critics, Collectors, Joiners, Spectators and Inactives. The top of the ladder start Creators which is the most sophisticated Category. Below the categories are given in details. ,

Creators: Creators are at the top of the ladder. They are the online consumers who publish blogs, maintain web pages, or upload videos to sites like YouTube at least once per month. They are generally young people. The percentage of the creators was $13 \%$ according to the Forrester's 2006-Q4 report. However in 2009-Q4 report it's rate increased to $24 \%$.

Critics: Critics participate in social media in two ways. First they comment on blogs and posting ratings and the second is they review on sites. In this level Participation is not as intense as being creators. The percentage of the critics was $19 \%$ according to the Forrester's 2006-Q4 report. However in Forrester's 2009-Q4 report it's rate increased to $37 \%$.

Collectors: Collectors save URL's on a social bookmarking service like del.icio.us or use RSS feeds on Bloglines, they create metadata that's shared with the entire community. Collectors represent the $15 \%$ of the population according to the Forrester's 2006-Q4 report. This rate increased to $20 \%$ in 2009. 
Joiners: This Group has just a kind of behavior. They just visit social networking sites and maintain their profiles. The rate of Joiners was $19 \%$ in 2006, but in 2009 there was a rapid increase in the percentage of the joiners. It increased more than $300 \%$ and $59 \%$ of the population are in the joiners group.

Spectators: This Group read blogs, listens to podcasts, watch videos of others, read online forums, read customer ratings and reviews and read tweets. According to the results of the Forester's research spectators are more likely to be women and have lowest income level. The percentage of the creators was $33 \%$ according to the Forrester's 2006-Q4 report. However in 2009-Q4 report its rate increased to $70 \%$.

Inactives: This group doesn't use to the social media tools. They don't participate activities, they are generally affected from others and they don't tell their friends about the products that interest them. This group was $52 \%$ in 2006, but today the rate decreased to the $17 \%$. Therefore this statistics proved that the percentage of social media usage increased gradually and at the end of the 2009 approximately $83 \%$ of the total population uses some or all kinds of social media tools.

Brandtzaeg (2010), conducted a Meta-Analysis and reviewed 22 articles related to the media user typologies. After analyzed the articles, he has formed his own Media User Typology Hierarchy. According to the Brandtzaeg social media user types are; Non-Users who don't use social media tools, Sporadic who are newcomers or low level participants, Debaters are the bloggers, Entertainment Users who participate in the social media such as online games in order to have fun, Socializes who use social media tools in order to be social, Luckers who mostly participate in order to kill their time, Instrumental Users who use social media tools in order to get information and finally Advanced users who use the most advanced social media technologies and use wide range of media Frequently. 


\section{SOCIAL MEDIA IN TURKEY}

In the first part of this section the evolution of the Internet in Turkey and the Internet usage habits of the Turkish population will be mentioned. In the second part, information about the preferences of Turkish Internet users related to the social media tools will be given.

\subsection{THE INTERNET USAGE IN TURKEY}

Turkey has been connected to the Global Internet World in 1993 by the collaboration of TUBITAK and ODTU (SOSCIALMEDIATR, 2010). In the Era of Web 1.0, plenty of technology companies invested millions of dollars to have place in the Internet World. However most of the companies went bankrupt just in a short time such as Ixir Company which has lost approximately 60 millions of dollars in the Internet world some companies who has applied feasibility analysis and healthy plans accomplished to survive in the unstructured Internet World (Odabaşı and Odabaş1, 2010). Contrarily, some of the companies accomplished to survive and they became the most attractive national internet sites in Turkey such as Mynet, Hurriyet and Superonline despite the limited number of Internet users (SOSCIALMEDIATR, 2010).

Later on, the number of Internet users has increased gradually with the effect of the ADSL technology and cheapen the computer cost. In 1997, the number of the total Internet users in Turkey was approximately 250.000. However, today these numbers are far out. Turkish population's internet usage rates of the last four years are shown in Graph-1. According to the Graph it is seen that in Turkey there are more than 30 million people who use the Internet (TUIK, 2010) by considering the overall Turkish population which is approximately 72.5 million as of 31 December 2009 (Turkish Statistics Yearbook, 2009). Thus, the penetration rate is about $41.6 \%$. 


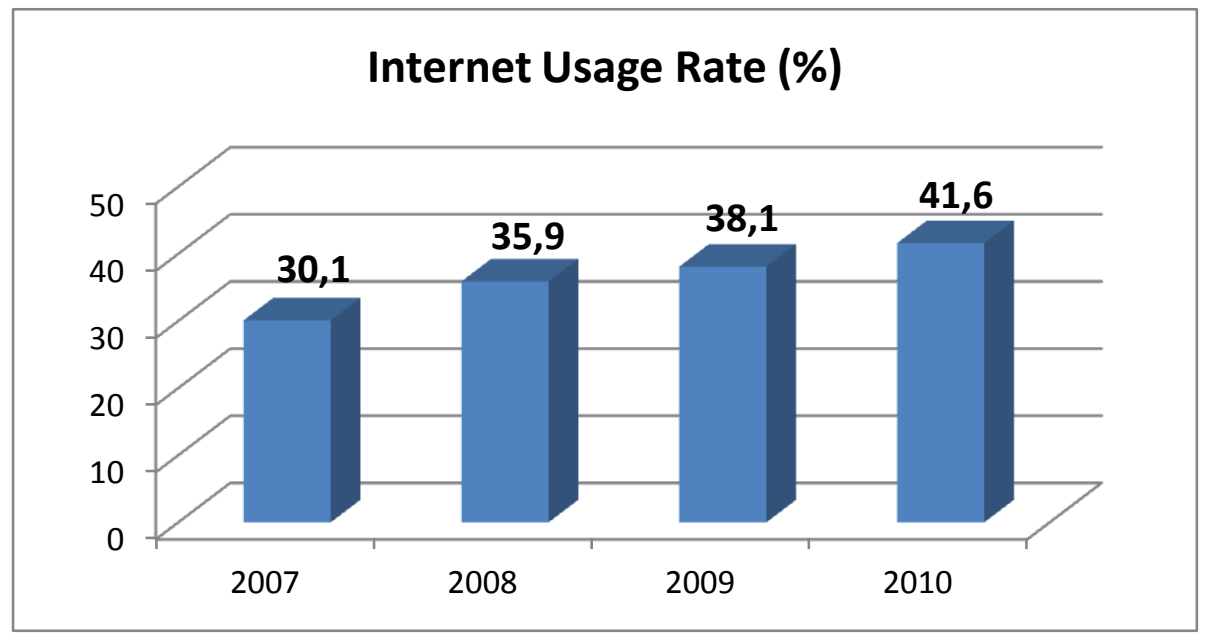

Graph 1: Internet Usage Rate in Turkey

Source: TUIK, News Bulletin, 2010, Volume: 148

When the place of Turkey among the countries throughout the World is analyzed, It is seen that Turkey has moved from $14^{\text {th }}$ place to $12^{\text {th }}$ place from 2009 to 2010 in the world. In addition according to the average hours of the Internet usage per visitor per month statistics among the countries throughout the World, Turkey has the $5^{\text {th }}$ place with an average of 33.9 hours (Read, 2010). Surprisingly, Turkish people spend more hours on the Internet than the most of the developed countries such as United States, United Kingdom and France.

If the demography of the Internet Users is analyzed; it is obvious that males use the Internet more than the females. In addition, the younger people use the Internet more than the older people. In the Graph-2, the \% of Internet Usage of the population according to the age groups and gender is shown. According to the TTNET's statistics, which is the biggest internet service provider in Turkey, 59\% of the Internet users $(17.7$ million) are male and $41 \%$ of them are female (12.3 million). 


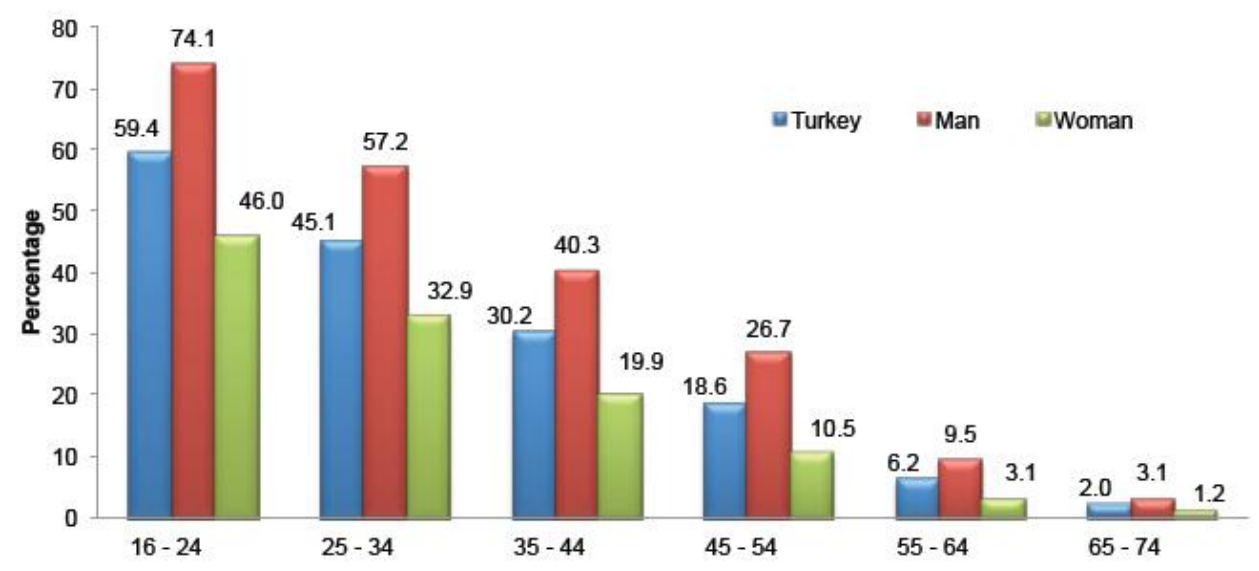

Graph 2: Internet Usage by Age Groups, 2009

Source: Information Society Statistics of Turkey, 2010

The percentage of the internet usage by educational background is shown in Graph-3. According to the Graph it can be said that the people who have a higher level of educational background, use the internet more.

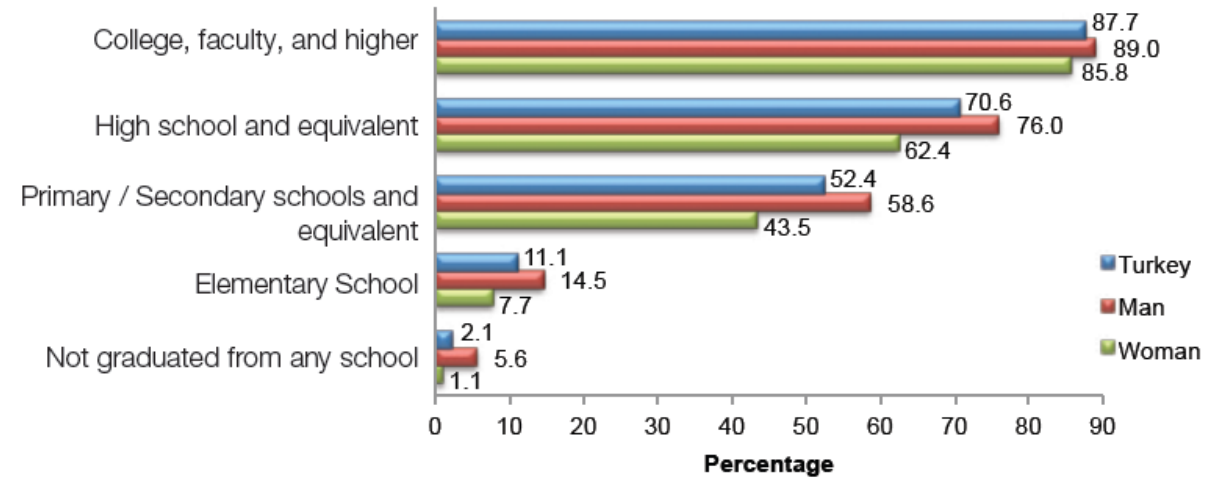

Graph 3: Internet Usage by Educational Background, 2009

Source: Information Society Statistics of Turkey, 2010

The Turkish population's Internet usage by Employment Status is shown in the Graph-4. According to the statistics approximately $90 \%$ of the students use Internet, also $56,8 \%$ of the waged and salaried people use internet. Just less than $20 \%$ of the Self-employed people, unpaid family workers, retired people and housewives use internet. 


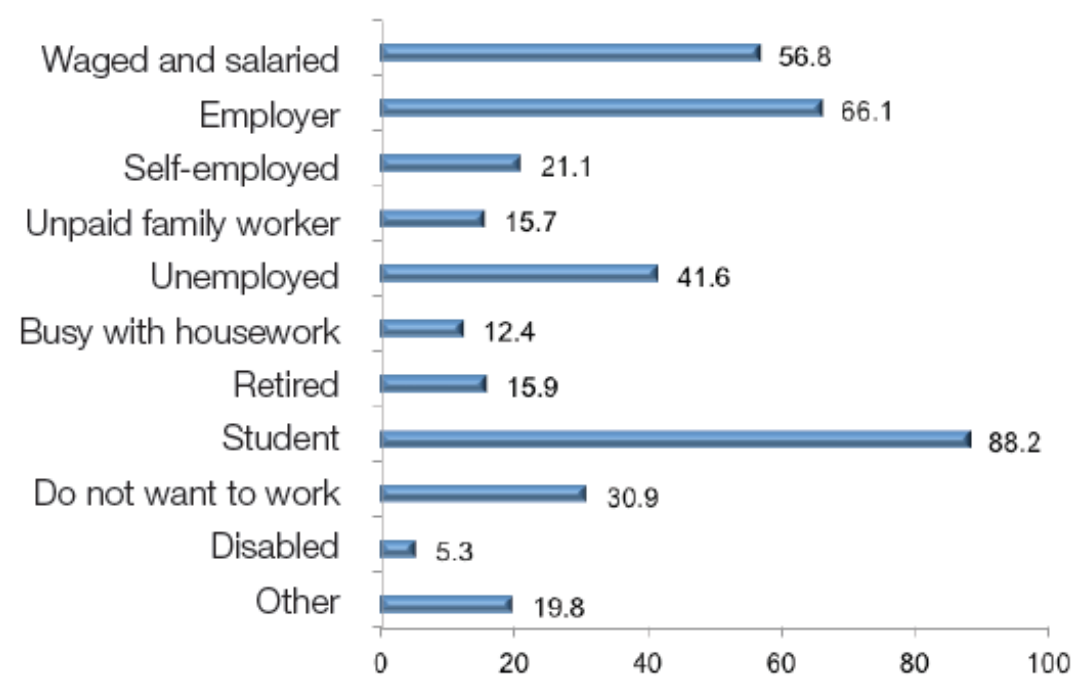

\section{Graph 4: Internet Usage by Employment Status, 2009}

Source: Information Society Statistics of Turkey, 2010

In the Graph-5, the places where the Turkish people access the Internet was shown based on the gender effect. According to the Figure, most people access the Internet from their houses. Women prefer to access Internet at home more than men; whereas men access the internet from the Internet cafes more than women.

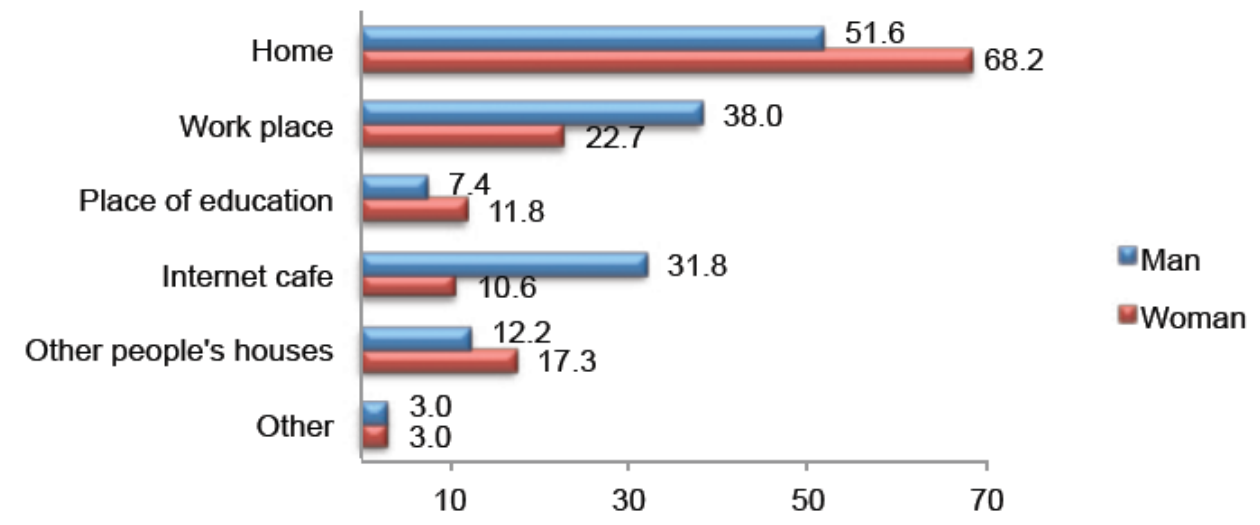

\section{Graph 5: Places of Internet Access, 2009}

Source: Information Society Statistics of Turkey, 2010

According to the TUIK's statistics, it is seen that the Internet was used most for sending and receiving the e-mails with a percentage of $72.4 \%$. Other purposes to use the Internet were; reading online news and newspapers (70\%), Sending messages to 
chat rooms, news groups, or online discussion forums, sending instant messages (Chat, MSN, Skype, real time communication with others) (57,8\%), Downloading or playing games, music, films, or images (56,3\%), Searching information about goods and services (52,9), Having phone conversations over the Internet / having video communication over the Internet $(49,8 \%)$, Searching information about health $(45,3 \%)$, Listening to radios or watching television channels that broadcast over the Internet (43,3 $\%)$.

\subsection{SOCIAL MEDIA USAGE IN TURKEY}

In the previous chapters it is mentioned about the importance and benefits of social media which has brought about a revolutionary change in communication and way of doing business. This wave of social media has hit Turkey too just with a little tardiness (Odabaşı and Odabaşı, 2010) and today Turkey has became one of the most important country in the social media world.

Tick-Tock Digital PR and Marketing Company formed a Social Media Landscape for Turkey which is shown in the Figure-3. This Landscape shows the most popular and used social media sites in Turkey based on specific categories. Since it seems that there are plenty of social media sites, only limited numbers of them surpass the social media. According to the Landscape; the most popular forum sites are ForumTR, Donanım haber and Forumceviz; video sharing sites are Youtube, Dailymotion, Vidivodo, AkıllıTV, İzlesene and Timsah; music sharing sites are Last.FM, Fizy and GrooveShark, document sharing sites are Google Docs, Scribd and Slideshare; information sharing sites are EkşiSozluk, Wikipedia, and İTUsozluk; business networking sites are Linkedin and Xing; photo sharing sites are Flickr and Picasa; social networking sites are Facebook, Yonja, Hi5, MySpace, Ortakantin, Bebo and FriendFeed; blogging services are Blogcu, Milliyet Blog Blogger, Azbuz and Mynet Blog. 


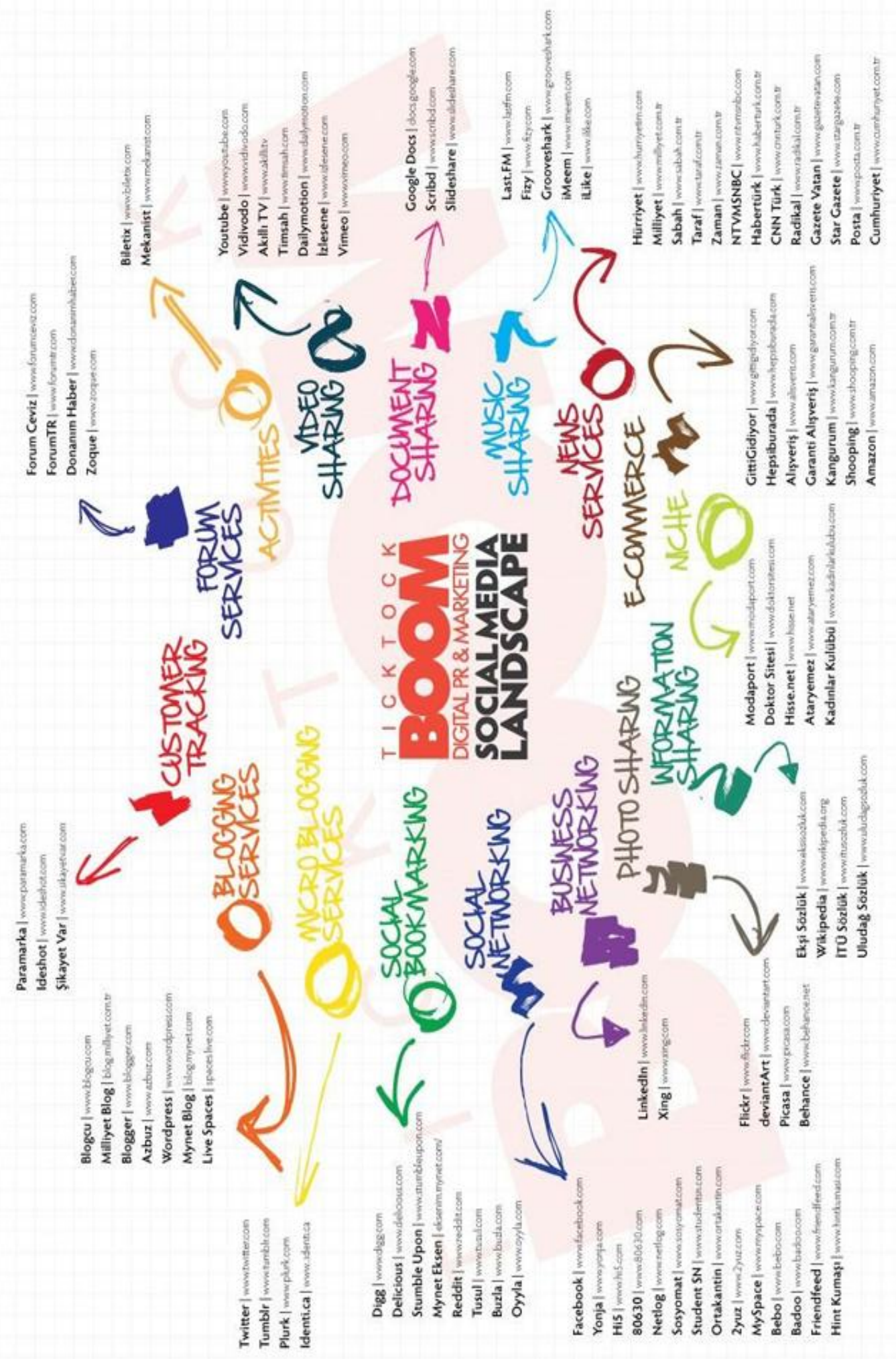

Figure 3: Social Media Landscape for Turkey

Source: www.trendweek.com, 2010 
If the social media sites in Turkey are analyzed, it is very obvious that Facebook which is a social networking site is far dominant among the other social media sites. Graph-6 shows the top social media sites in Turkey from April, 2010 to April, 2011 (STATCOUNTER, 2011). In the Graph it is seen that Facebook is the most common used social media site in Turkey. Other popular social media sites are Twitter, Stumbleupon, Youtube and FriendFeed in Turkey. Interestingly, when the penetration of the facebook increase, the penetration of other social media sites decreases; or vice versa. However, these statistics do not include the Forum sites and Blogs in Turkey.

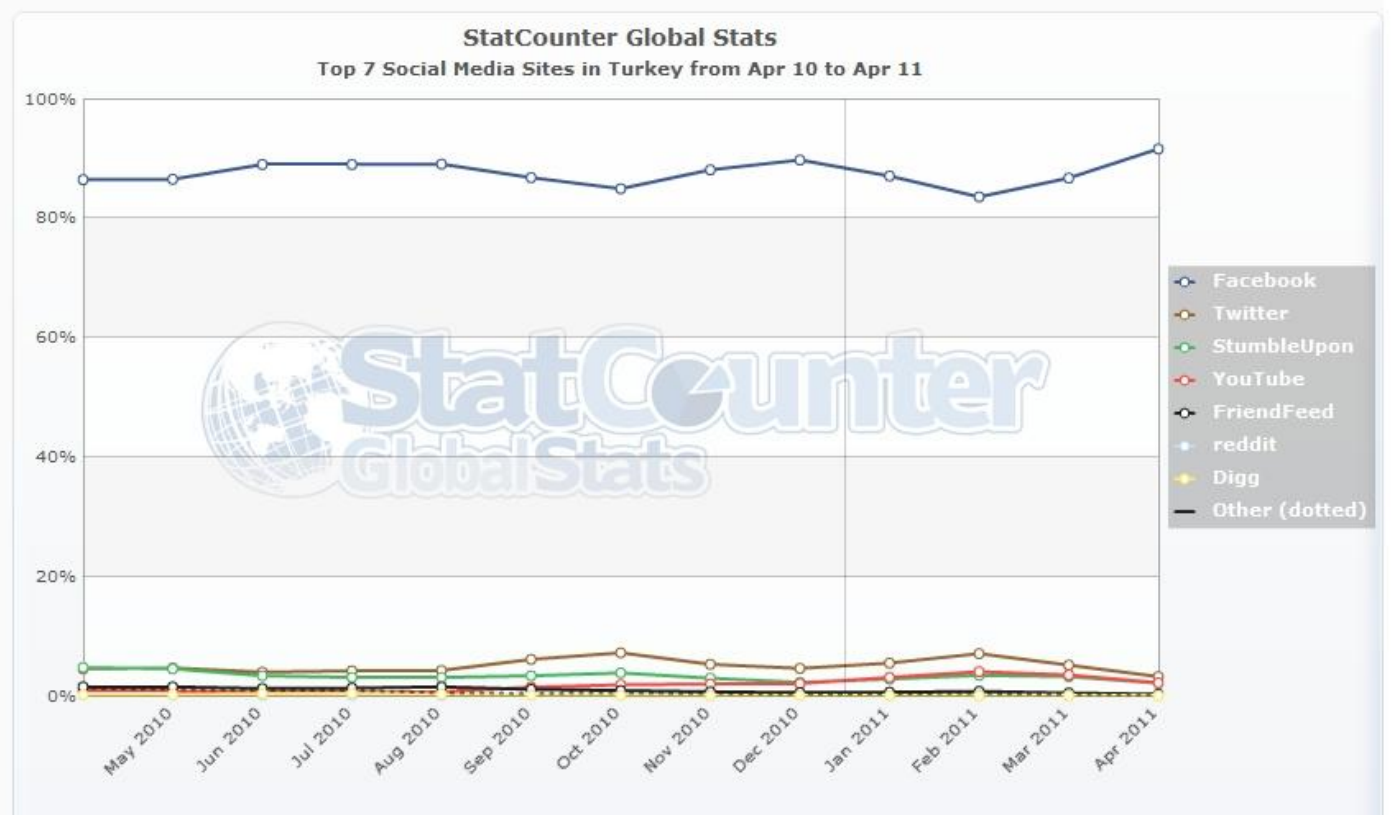

Graph 6: Top social media sites in Turkey

Source: StatCounter, 2011

In addition to these statistics, Google trends show the search volume Index from between the years $2004-2011$ in the Graph-7. The results are very close to the Statcounter statistics. Facebook is the most searched social media sites. Youtube and Twitter are the followers of Facebook. In the Graph-X, there is a sharp decline of youtube at the end of the year 2007. The reason is that the Turkish Government prohibited to access to Youtube because of improper contents. Also if we compare the 
trends in Turkey and trends in Worldwide, it is seen that you were popular at the same time both in Turkey and Worldwide. However Facebook had started to be popular in worldwide in 2005, while it had started to be popular in 2007 in Turkey. In addition twitter first appeared in Worldwide at the end of 2008, while at the end of 2009 in Turkey.

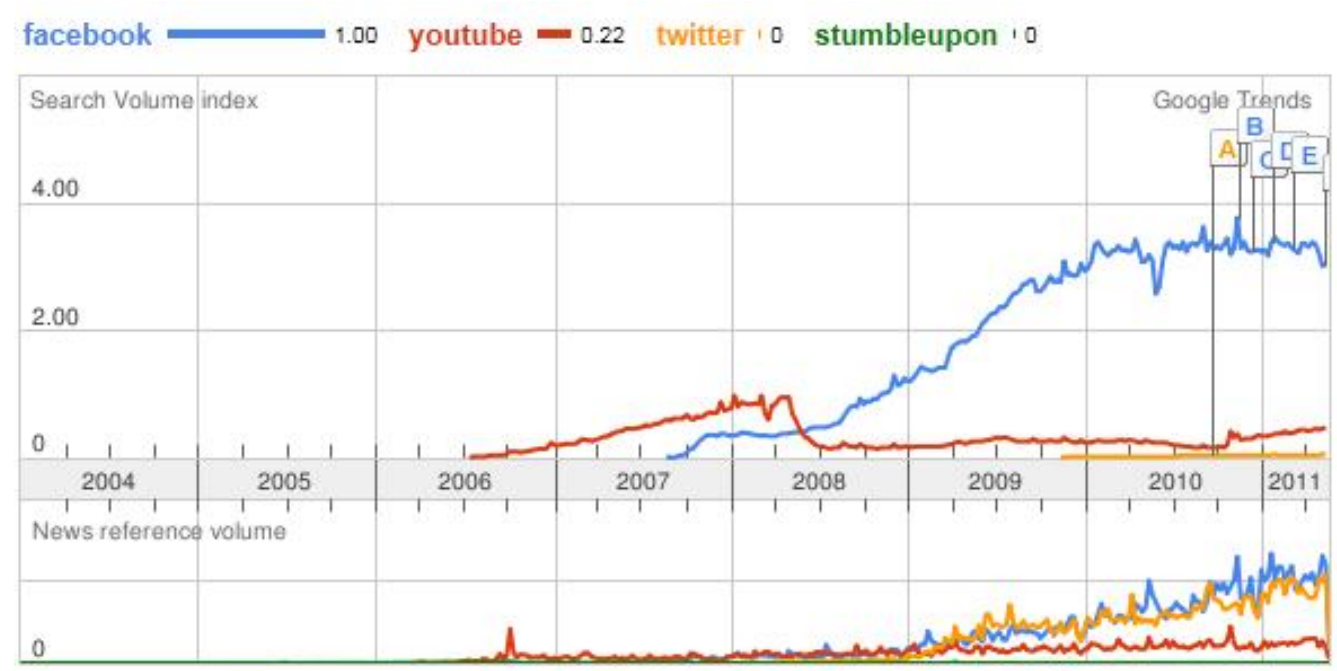

\section{Graph 7: Search Volume Index}

Source: Google Trends, 2011

Since social media is new, there is no structured statistics especially related to the demography and the preferences of the Turkish social media users. Some Major Players of the social media world such as Youtube and Twitter provides the statistics for plenty of countries except for Turkey. So it is almost impossible to get official information about these social media websites. However, statistics of Facebook in Turkey are provided by socialbakers.com. If the penetration of Facebook in Turkey which is approximately $90 \%$ among internet users (Akbaba, 2010) is considered, the demography of the social media users in Turkey may be generalized by looking at the Facebook statistics.

SocialBakers.com is one of the most reliable and professional online company that provides Facebook statistics throughout the world. According to the SocialBakers (2011); in Turkey, there are 28455820 facebook users as of May, 2011, and Turkey 
has the $4^{\text {th }}$ rank among all the countries in the world based on the number of facebook users. Facebook penetration of Turkish Population is $36.57 \%$ and penetration of online population is $81,3 \%$. Graph-8 shows the change in the number of Facebook users in Turkey. It is seen that the number of Facebook users has increased gradually in Turkey.

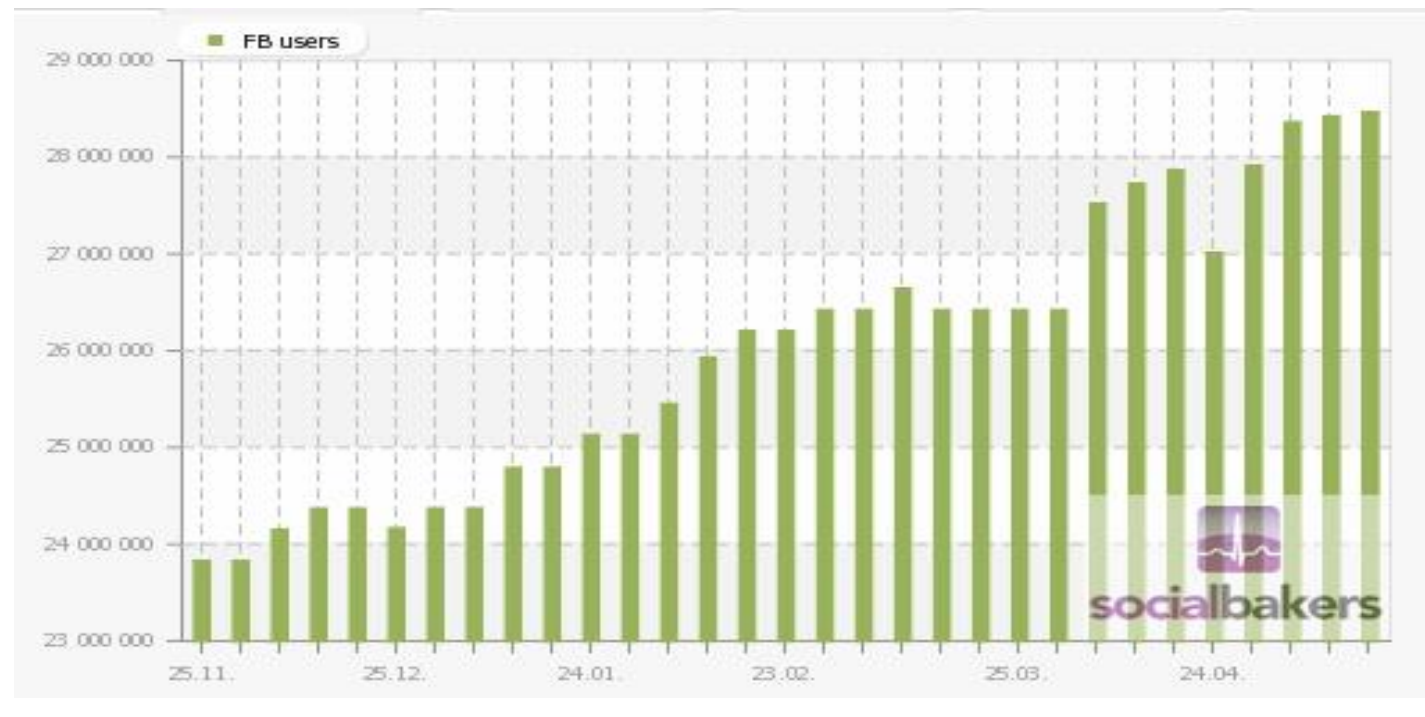

Graph 8: The number of Facebook Users in Turkey

Source: www.SocialBakers.com, 2011

The age and the gender distribution of the Facebook users in Turkey is shown in the Graph-9. According to the Figure, $33 \%$ of the users are at the age 18-24, $28 \%$ of them are at the age 25-34. In addition, the Figure shows that $64 \%$ of the users are male and $36 \%$ of them are female (SOCIALBAKERS, 2011).
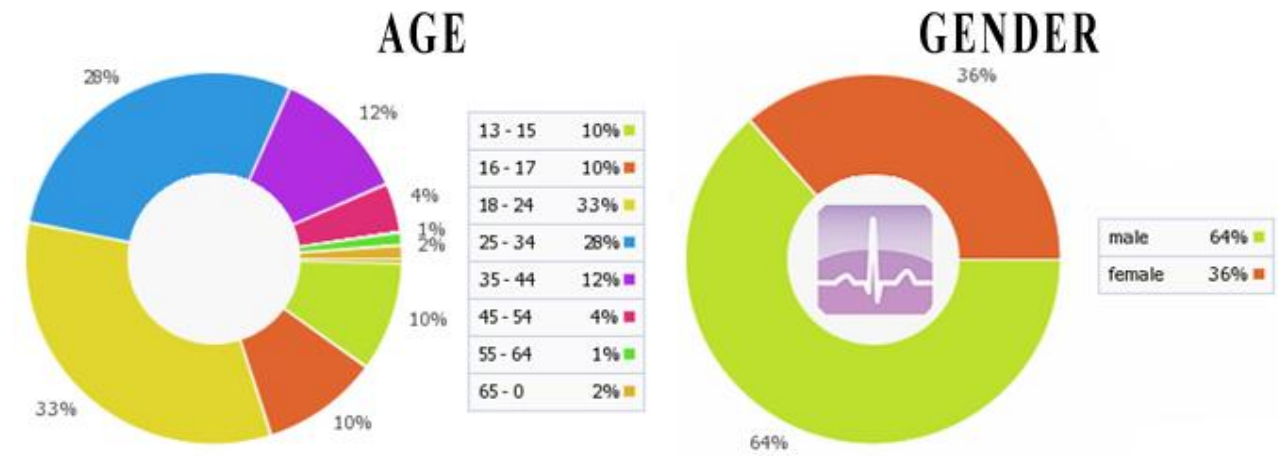

Graph 9: The age and the gender distribution of the Facebook users in Turkey

Source: www.SocialBakers.com (2011) 
If the top Turkish pages of the Facebook are analyzed, Galatasaray and Fenerbahçe which are the most important football teams are ranked the $1^{\text {st }}$ and $2^{\text {nd }}$. Galatasaray has approximately 5,5 million members, while Fenerbahçe has approximately 4 millions. Emre Aydın's who is a Musician has about 2,5 million fans in his Facebook page. The top 20 Turkish pages include 7 Musicians, 3 Sport teams, 3 Comedians, 1 Travel, 1 Footbal Star, 1 Tv series, 1 Actor, 1 Food, 1 Politician, and 1 Brand (FAMECOUNT, 2011).

Facebook is also a very important platform for the Marketers which is mentioned in the previous sections. Therefore, the companies aimed to have more fans in their Facebook pages. Top Turkish brands, the number of their fans, and last month fan growth of the pages in the Facebook are shown in the Table-3. Avea which is a mobile network provider has the most fans in Facebook which is about 1.35 millions. Turkcell which is the most important competitors of Avea is at the $2^{\text {nd }}$ rank. Nike a sportswear company is at the $3^{\text {rd }}$ rank. TTnet which is at the telecommunication sector at the $4^{\text {th }}$ position. OXXO, a clothing company for the women, has been placed at the Top5. If the top 50 brands in Facebook is analyzed it can be said that, in general the Facebook users in Turkey prefer to be a fan of the brands in telecommunication sector, Clothing companies, Online shopping companies and FMCG sector.

Table 3: Top Followed Turkish Brands on Facebook

\begin{tabular}{|c|c|c|c|c|c|c|c|}
\hline$\#$ & Name & Fans & Growth & $\#$ & Name & Fans & Growth \\
\hline 1. & Avea & 1350113 & $+4.84 \%$ & 11. & Trendyol & 327169 & $+18.32 \%$ \\
\hline 2. & $\underline{\text { Turkcell }}$ & 936387 & $+45.56 \%$ & 12. & Avon Türkive & 309549 & $+16.28 \%$ \\
\hline 3. & Nike Football / Türkive & 752934 & $+7.04 \%$ & 13. & markafoni & 298715 & $+15.69 \%$ \\
\hline 4. & ITNET & 475896 & $+20.82 \%$ & 14. & Favori Jewellery (Turkey) & 280996 & $+19.82 \%$ \\
\hline 5. & $\underline{0 \times 0}$ & 439580 & $+38.84 \%$ & 15. & Starbucks Türkive & 276629 & $+3.21 \%$ \\
\hline 6. & GittiGidivor & 435218 & $+17.75 \%$ & 16. & Mavi Jeans & 273928 & $+10.49 \%$ \\
\hline 7. & $\underline{\text { Ülker }}$ & 406574 & $+38.53 \%$ & 17. & $\underline{\text { Tivibu }}$ & 271263 & $+2.79 \%$ \\
\hline 8. & $\underline{\text { Garanti Bankası }}$ & 403055 & $+125.52 \%$ & 18. & Greenpeace Akdeniz - Türkive & 237435 & $+4.15 \%$ \\
\hline 9. & Cizi & 395665 & $+37.68 \%$ & 19. & gnctrkcll & 232995 & $+72.97 \%$ \\
\hline 10. & Akbank & 390500 & $+172.57 \%$ & 20. & Volkswagen Türkive & 211514 & $+23.31 \%$ \\
\hline
\end{tabular}

Source: www.SocialBakers.com, 2011 


\section{RESEARCH DESIGN AND METHODOLOGY}

In this section, research design and methodology of the study is presented under the subsections; research objective, research design, questionnaire design, measurement of independent and dependent variables, sampling and data collection.

\subsection{RESEARCH OBJECTIVE}

Mainly Inspired by the Social Technographic Model, the primary objective of this study is to classify the users according to their usage preferences of social media activities; and determine their demographic affinities and content preferences. A secondary objective is to explore what are the motivations to be present and/ or actively use social media tools. The marketing objective of the study is to inform about, how social media can be used as a marketing tool in marketing research, promotion, segmentation, branding, and customer relationship management areas. Another marketing objective of this study is to determine the demography of the clusters which are formed based on the usage preferences of social media tools. Therefore, marketers will be clearer where they can find their target customers in the social media world.

Following research objectives are derivatives of this study: Exploring the motives of using social media, exploring the demographic differences between the groups of social media users.

\subsection{RESEARCH TYPES}

In this study, two types of research are used; an exploratory research followed by a descriptive one. The objective of exploratory research is to explore or search through a problem or situation to provide insights and understanding (Malhotra and Peterson, 2006). There are almost no previous academic researches on social media typology which was conducted in Turkey. Therefore this study works with the exploratory research. Exploratory research is seen as complementary of quantitative research and quite often exploratory researches are followed by quantitative researches (Gegez, 2007).

In the exploratory research, in-depth interview method which was guided by semistructured questionnaire is used. After the exploratory research; a descriptive, single cross 
sectional research design is implemented in this study using survey method. Survey is a method of "questioning the individuals on a topic or topics, and describing their responses". This method also allows researchers to study larger groups of individuals more easily (Jackson, 2008, p: 17). The study is planned to be conducted on large groups of Internet users thus this method is very convenient for the study.

\subsection{QUESTIONNAIRE DESIGN}

The questionnaire is developed in light of the exploratory research and literature review in order to attain objectives of the study. The exploratory research was applied to total 30 respondents who are high school or university students. During In-Depth interview the respondents are asked "what are the motives of using social media?" and "which types of contents they prefer to share in the social media world?" Subsequently, the results were compared with the literature. As motives; "keep updated" and "cheaper communication" variables were determined apart from the literature. As content categorize; "self content", "art", "romantic", extraordinary", and "horror "were added to the questionnaire in addition to the literature.

The questionnaire is composed of six sections. In the first section there are two questions related to the Internet usage such as how many hours they spend time on the Internet, and which tools they use in order to the access to the Internet.

In the second section, the questions are aimed to attain the motives of using social media. The third section composes of the questions related to the usage preferences of the activities that are provided by the social media technologies. In the forth section, the questions are about the preferences of content categories that are shared on the social media sites. The fifth section is about following the companies on social media. In the sixth section of the questionnaire there are demographic questions such as gender, age, occupation, marital status, income and education.

The Likert Scale is one of the most effective tools in collecting data in survey type studies. It is an ordered, one-dimensional scale from which respondents choose one option that best aligns with their view (Akman, Misra and Altindag, 2011). In the present study, the data was collected using a five-point Likert Scale ("Never", "Rarely", 
"Sometimes", "Very Often", "Always") for the variables of the second, third, and fourth sections of the questionnaire.

\subsection{SAMPLING AND DATA COLLECTION}

Target population of this study consists of all the Internet users in Turkey. According to TUIK (2010), in Turkey there are approximately 30.1 million Internet users. In order to reach the target population convenience sampling a non-probabilistic sampling method (Malhotra, 2007) was used.

Researchers in general work to a 95 percent level of confidence while determining the needed sample size. In addition; generally for the business and management studies, researchers prefer to estimate the populations' characteristics within $3-5$ confidence intervals (Saunders, Lewis and Thornhill, 2007). Therefore, in this study sample size is determined according to $95 \%$ confidence level and $3 \%$ confidence interval in order to have more generalizable results. To determine the needed sample size Cochran's (1963) equation was used and as it is seen in the formula below the adequate sample size was found as 1067.

$$
\mathrm{n}=\frac{\mathrm{p} \cdot \mathrm{q} \cdot \mathrm{z}^{2}}{\mathrm{e}^{2}}=\frac{(0.5) \cdot(0.5) \cdot(1.96)^{2}}{(0.03)^{2}}=1067 \text { people }
$$

Questionnaire design was formed as hard copy which is shown in Appendix-A. The copy of the questionnaire was distributed to the respondents throughout Turkey, but especially in Bursa, Yalova, Istanbul, Zonguldak and Kayseri between the dates of 15 March and 12 April, 2011. Consequently the total 1105 responds to the questionnaire was reached in the target time period. After the evaluation of the questionnaires 104 forms were eliminated due to missing data; valid 1001 questionnaire were used for the statistical testing. 
Table 4: Variables of the Study

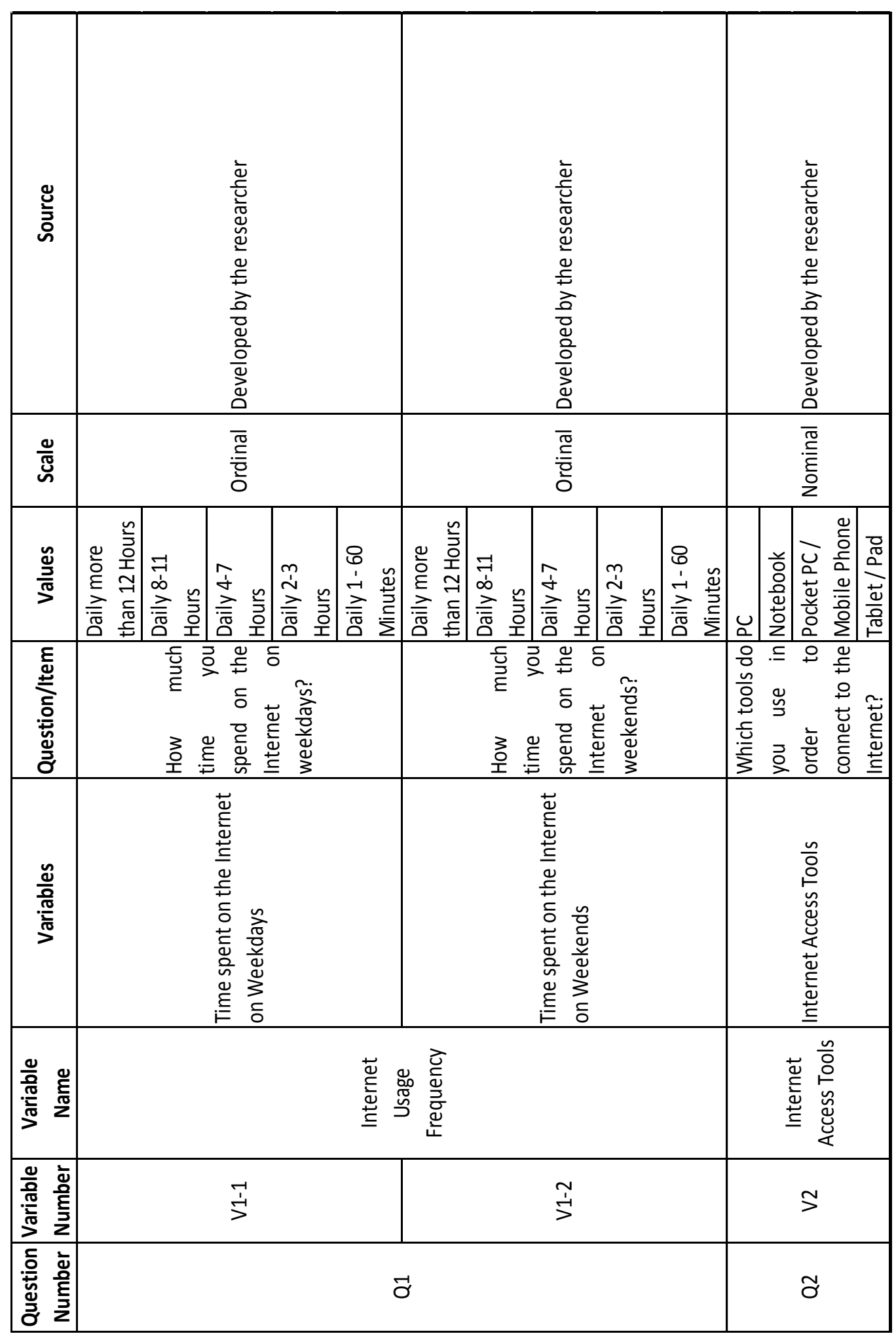


Table 4: Variables of the Study (Continued)

\begin{tabular}{|c|c|c|c|c|c|c|c|c|c|c|c|c|c|c|c|c|}
\hline 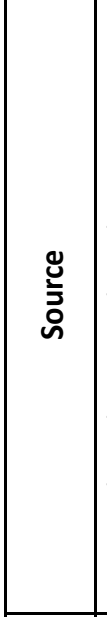 & 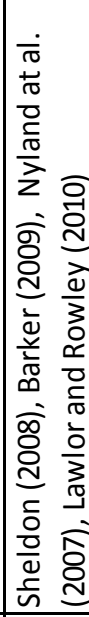 & 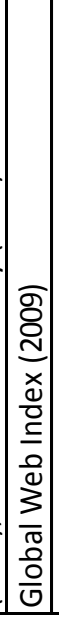 & 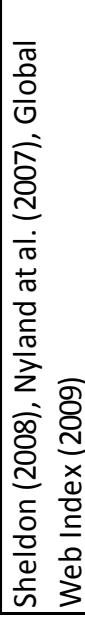 & 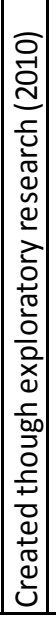 & 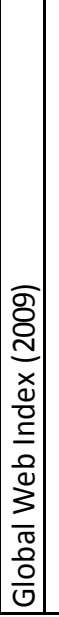 & 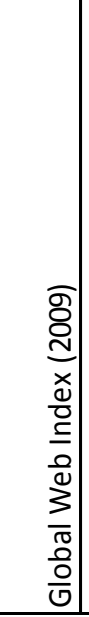 & 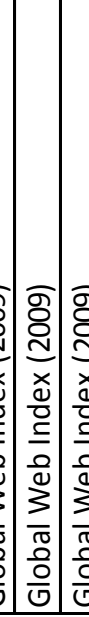 & 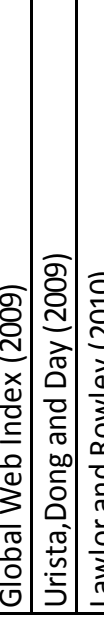 & 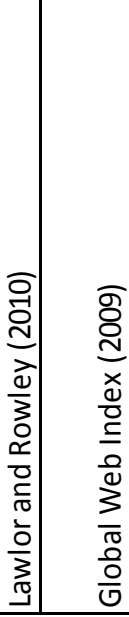 & 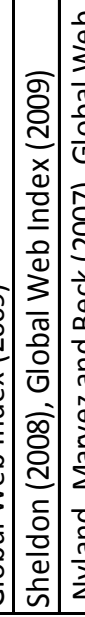 & 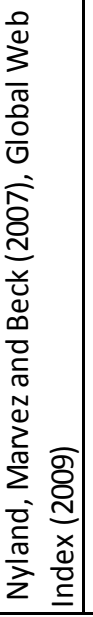 & 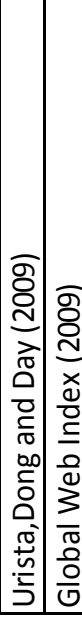 & 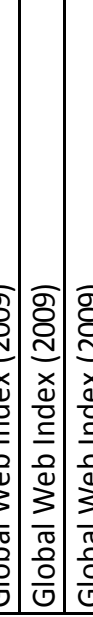 & 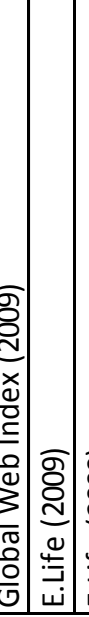 & 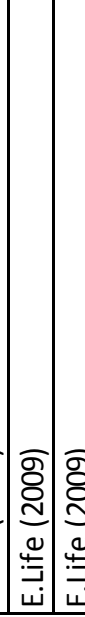 & 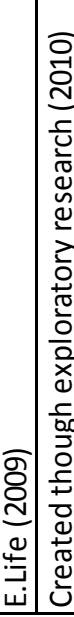 \\
\hline$\frac{\varrho}{\widetilde{ల}}$ & \multicolumn{16}{|c|}{ ల్ల్ర } \\
\hline$\frac{\breve{g}}{\frac{\tilde{J}}{\sigma}}$ & \multicolumn{16}{|c|}{ 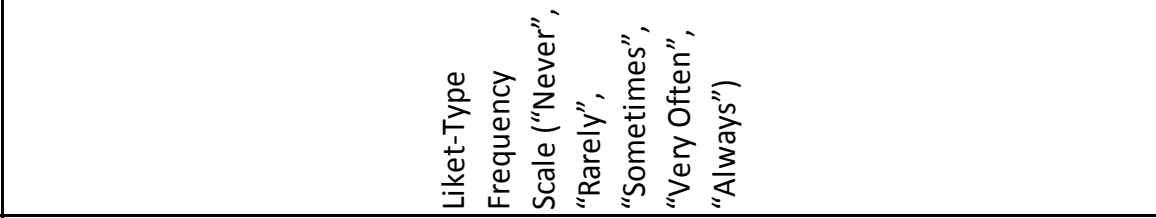 } \\
\hline 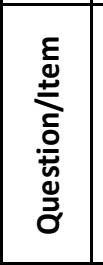 & \multicolumn{16}{|c|}{ 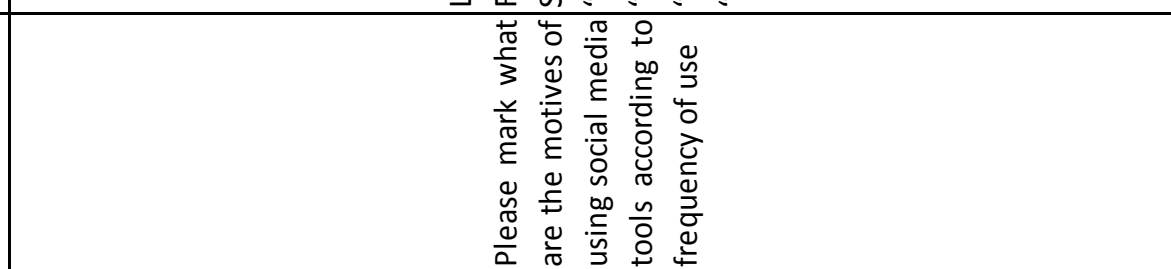 } \\
\hline 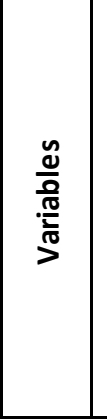 & 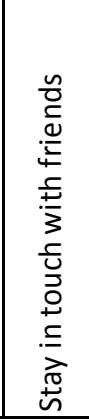 & 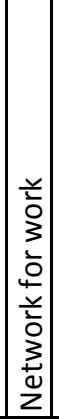 & 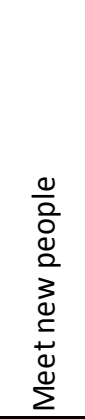 & 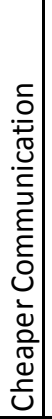 & 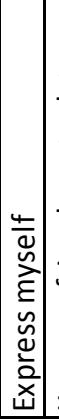 & 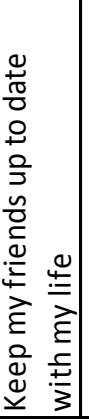 & 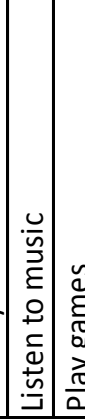 & 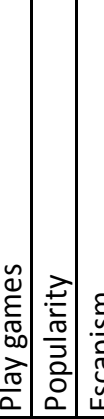 & 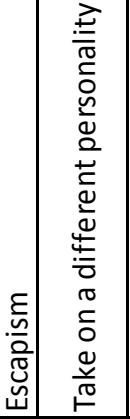 & 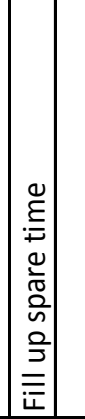 & 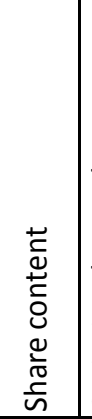 & 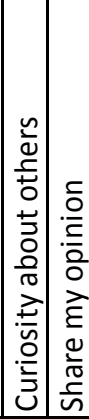 & 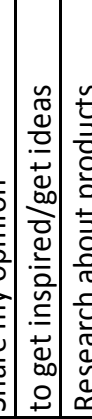 & 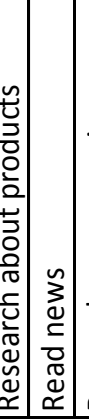 & 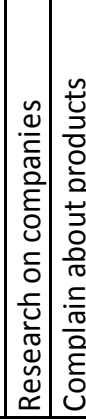 & 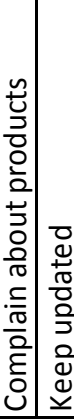 \\
\hline 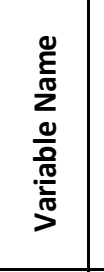 & \multicolumn{16}{|c|}{ 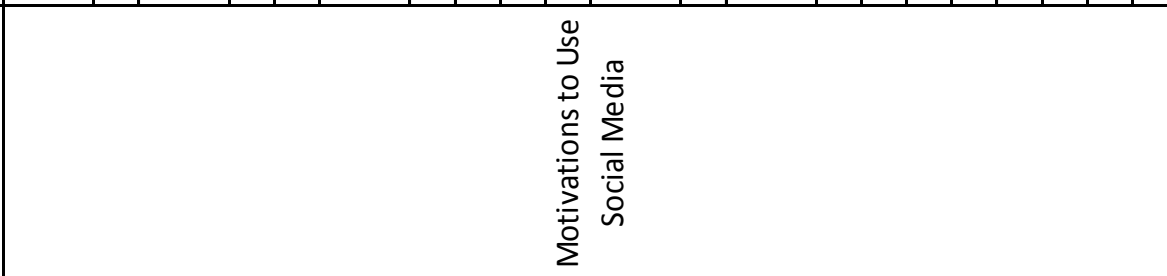 } \\
\hline 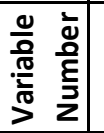 & $\stackrel{m}{m}$ & $\stackrel{\dot{m}}{\grave{m}}$ & $\stackrel{m}{m}$ & $\stackrel{m}{p}$ & 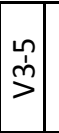 & $\stackrel{m}{s}$ & 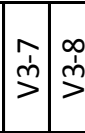 & 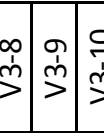 & 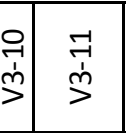 & $\begin{array}{l}\approx \\
\dot{m} \\
\stackrel{3}{2}\end{array}$ & $\stackrel{m}{\vec{m}}$ & 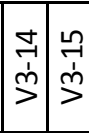 & 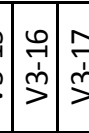 & 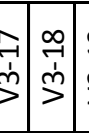 & $\begin{array}{ll}\stackrel{\rho}{7} & \stackrel{P}{1} \\
\dot{m} & \stackrel{m}{m}\end{array}$ & 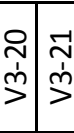 \\
\hline 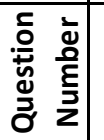 & \multicolumn{16}{|c|}{$\tilde{o}$} \\
\hline
\end{tabular}


Table 4: Variables of the Study (Continued)

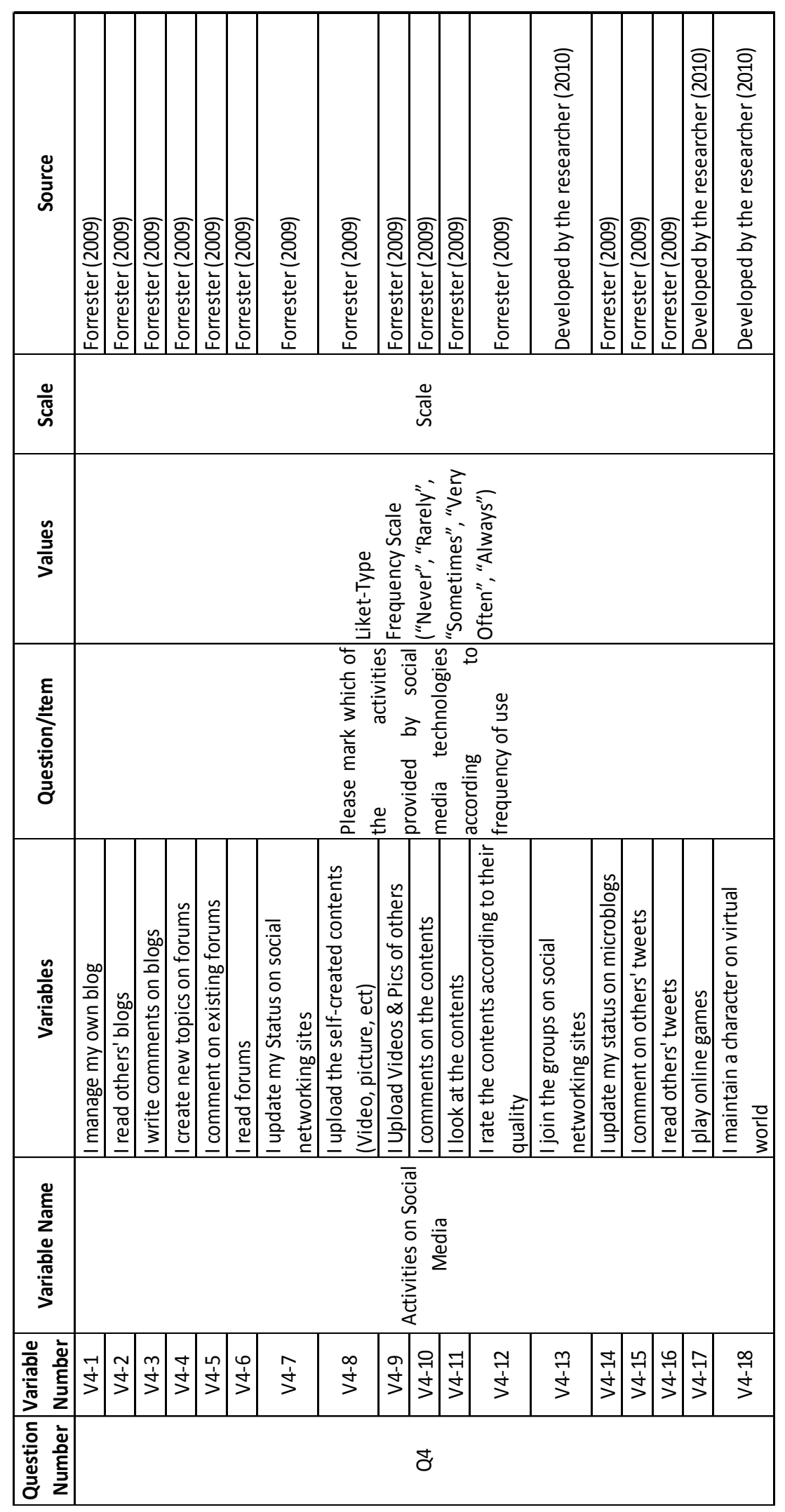


Table 4: Variables of the Study (Continued)

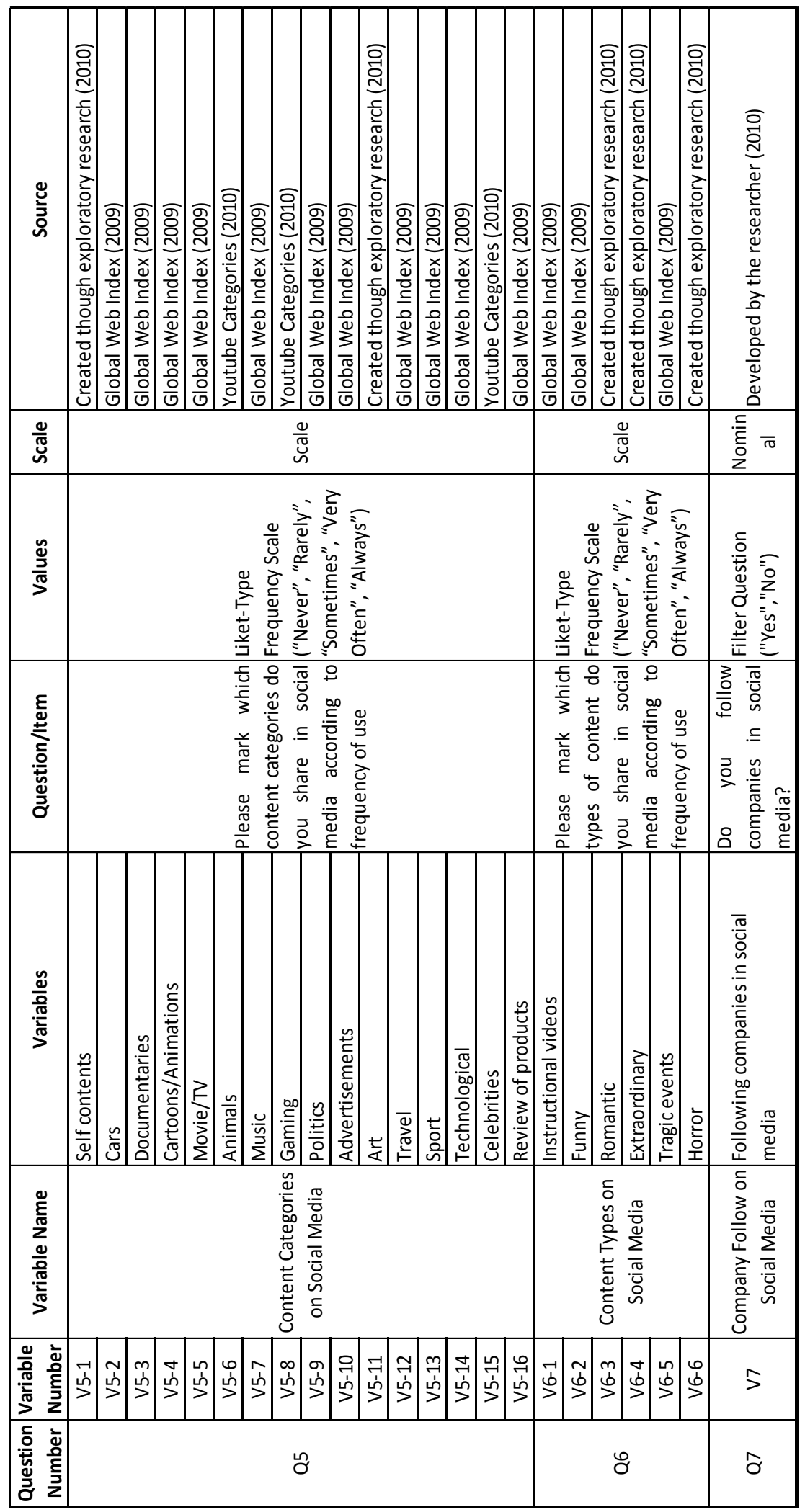


Table 4: Variables of the Study (Continued)

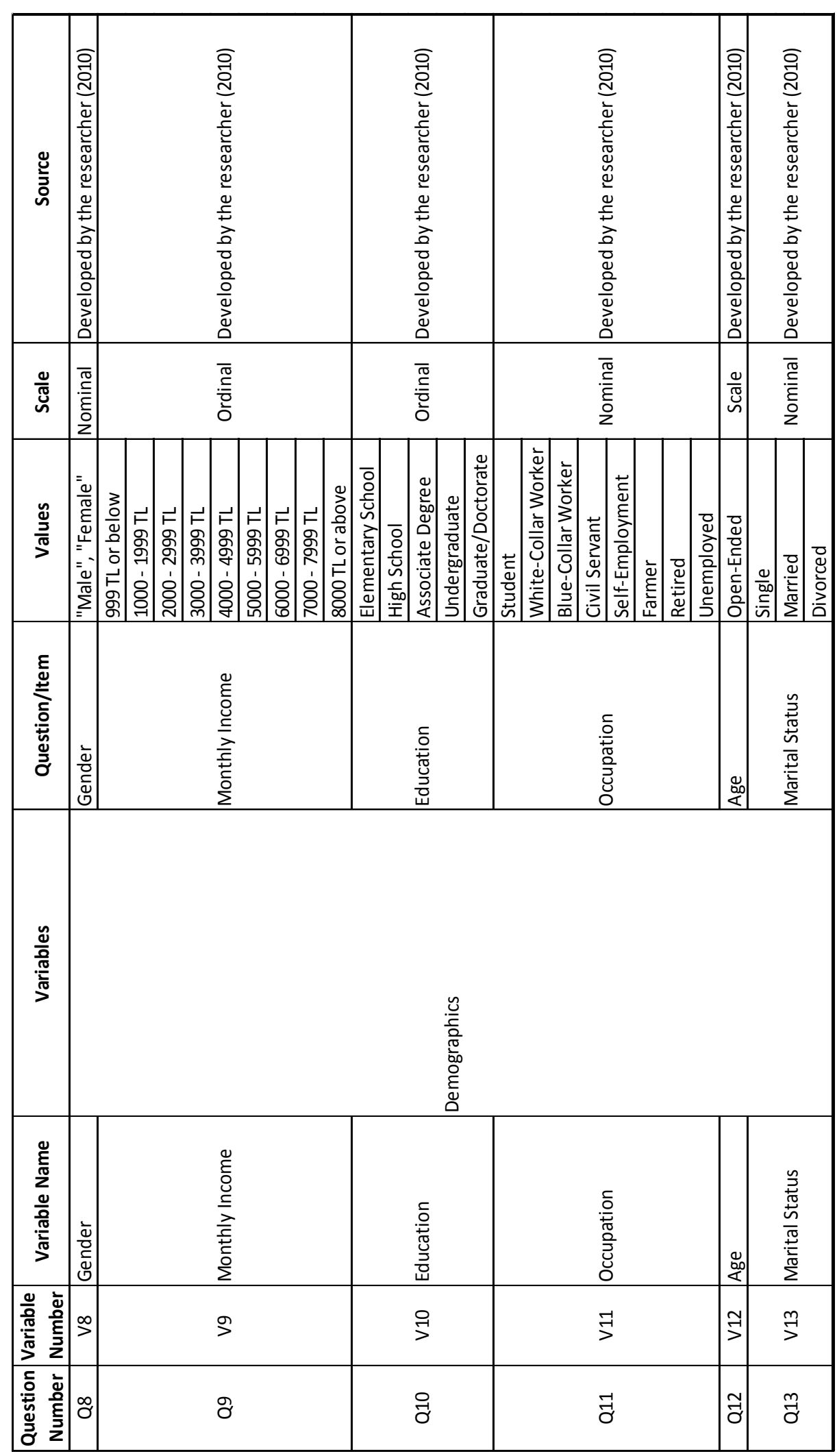




\section{FINDINGS}

In this section, the findings of the analyses are presented beginning from descriptive statistics of the sample furthermore the results of the statistical analysis (Factor, Cluster, Chi-Square, and ANOVA) will be discussed.

\subsection{DESCRIPTIVE STATISTICS FOR THE SAMPLE}

Table-5 indicates the gender and marital status of the total sample. The sample is composed of $60 \%$ males and $40 \%$ females. As it is mention in previous section the gender distribution of the sample is very parallel with Turkey's internet users' ratio (59 $\%$ male and $41 \%$ female). Most of respondents are single (74.3\% of the total sample), 24.6 of the sample is married. $1.1 \%$ of the sample which is equal to 11 respondents is divorced.

Table 5: Gender and Marital Status of the Sample

\begin{tabular}{|l|r|r|}
\hline \multicolumn{3}{|c|}{ Gender } \\
\hline & Frequency & Percent \\
\hline Female & 397 & 40 \\
\hline Male & 604 & 60 \\
\hline Total & 1001 & 100 \\
\hline
\end{tabular}

\begin{tabular}{|l|r|r|}
\hline \multicolumn{3}{|c|}{ Marital Status } \\
\hline & Frequency & \multicolumn{1}{c|}{ Percent } \\
\hline Married & 246 & 24,6 \\
\hline Single & 744 & 74,3 \\
\hline Divorces & 11 & 1,1 \\
\hline Total & 1001 & 100,0 \\
\hline
\end{tabular}

Table- 6 indicates the income level and the occupation distribution of the total sample. Approximately 50\% of the sample is composed of students. In addition $20 \%$ of the sample is civil servant. Although sample is composed of every income level, $79 \%$ of the respondents' income level is below 3.000 TL.

Table 6: Occupation and Income Level of the Sample

\begin{tabular}{|l|r|r|l|r|r|}
\hline \multicolumn{3}{|c|}{ Occupation } & \multicolumn{3}{c|}{ Income Level } \\
\hline & Frequency & Percent & & Frequency & Percent \\
\hline Student & 489 & 48,9 & $\begin{array}{l}\text { Less than 1000 } \\
\text { TL }\end{array}$ & 219 & 21,9 \\
\hline Civil Servant & 205 & 20,5 & $1000-1999$ TL & 388 & 38,8 \\
\hline
\end{tabular}




\begin{tabular}{|l|r|r|l|r|r|} 
Other & 143 & 14,3 & $2000-2999 \mathrm{TL}$ & 187 & 18,7 \\
\hline Unemployed & 71 & 7,1 & $3000-3999 \mathrm{TL}$ & 107 & 10,7 \\
\hline Self-Employment & 32 & 3,2 & $4000-4999 \mathrm{TL}$ & 36 & 3,6 \\
\hline Blue-Collar Worker & 29 & 2,9 & $5000-5999 \mathrm{TL}$ & 24 & 2,4 \\
\hline White-Collar Worker & 23 & 2,3 & $6000-6999 \mathrm{TL}$ & 14 & 1,4 \\
\hline Retired & 8 &, 8 & $7000-7999 \mathrm{TL}$ & 9 &, 9 \\
\hline Farmer & 1 &, 1 & 8000 and over & 17 & 1,7 \\
\hline Total & 1001 & 100,0 & Total & 1001 & 100,0 \\
\hline
\end{tabular}

Table-7 indicates the education level and age distribution of the sample. According to the table, the education level of the sample is mostly composed of high school (41.7\%) and university (4 year degree) (31.3\%). When the age distribution of the sample is analyzed, it is clearly visible that most of the sample is under the age 34 (83\%).This percentage is close to the age distribution of the Internet users in Turkey which is approximately $75 \%$.

Table 7: Education Level and Age Distribution of the Sample

\begin{tabular}{|l|r|r|l|r|r|}
\hline \multicolumn{3}{|c|}{ Education Level } & \multicolumn{3}{c|}{ Age } \\
\hline & Frequency & Percent & & Frequency & Percent \\
\hline Master-Doctorate & 113 & 11,3 & Less than 18 & 278 & 27,8 \\
\hline University (4 year degree) & 313 & 31,3 & $\mathbf{1 8 - 2 4}$ & 254 & 25,4 \\
\hline University (2 year degree) & 123 & 12,3 & $\mathbf{2 5 - 3 4}$ & 299 & 29,9 \\
\hline High School & 417 & 41,7 & $\mathbf{3 5 - 4 4}$ & 101 & 10,1 \\
\hline Elementary School & 34 & 3,4 & $\mathbf{4 5}$ and over & 42 & 4,2 \\
\hline Missing & 1 &, 1 & Missing & 27 & 2,7 \\
\hline Total & 1001 & 99,9 & Total & 1001 & 100,0 \\
\hline
\end{tabular}

Graph-10 indicates the time that the respondents spend on the Internet. According to the Graph, 35\% of the respondents daily spend less than 1 hour on the Internet during weekdays, but this percentage decreases to $27 \%$ during weekends. Approximately $30 \%$ of the respondents spend 2-3 hours daily and $20 \%$ of them spend 47 hours on the Internet during weekdays. On weekends, $35 \%$ of the respondents spend 2-3 hours and $24 \%$ of them spend 4-7 hours. The percentage of the respondents who 
spend more than 8 hours daily on the Internet is very close during weekdays and weekends.

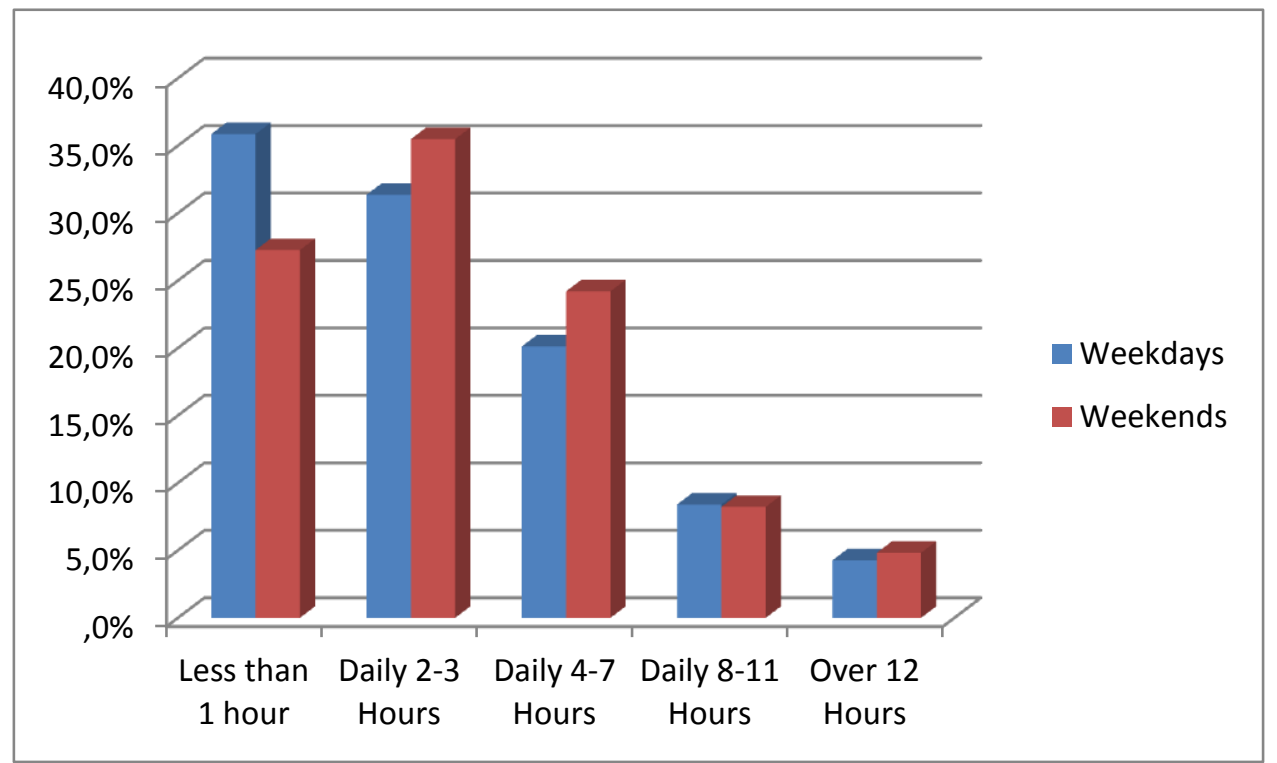

Graph 10: Time spend on the Internet

As seen from Graph-11, 85\% of the respondents use notebook in order to access Internet. $31 \%$ of them use PC's and $25 \%$ of them prefer PDA's or Mobile Phone's to get online. Since the Tablet's and Pad's are recent technologies in the market just $3 \%$ of the respondents use them to access Internet.

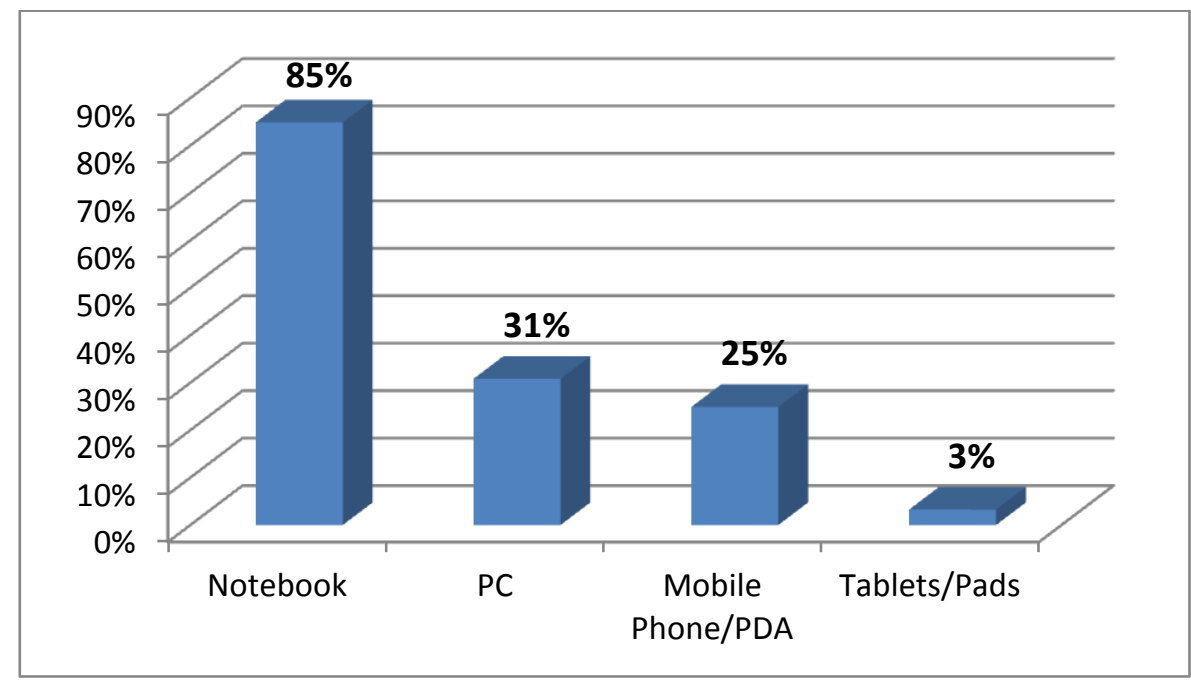

Graph 11: Tools used to connect to the Internet. 
Graph-12 indicates the social media tool preferences of the users. Social media term is used to generalize all social media tools. However the preferences and usage percentage of each social media tool differs from one another. Blue bars show the usage percentage of each social media tools at least one time. Red bars show the average usage percentage of each social media tools. It is very clear that social networking sites are the most preferred tool that more than $90 \%$ of the internet users use SNS's and average usage rate is over $50 \%$. Content Communities are the second most preferred social media tool. Forums and blogs usage rates are very similar that $\mathrm{s}$ about $57 \%$ (At least one) and 22 (average usage rate). The least preferred social media tools in Turkey are the Virtual Worlds and Micro-Blogs.

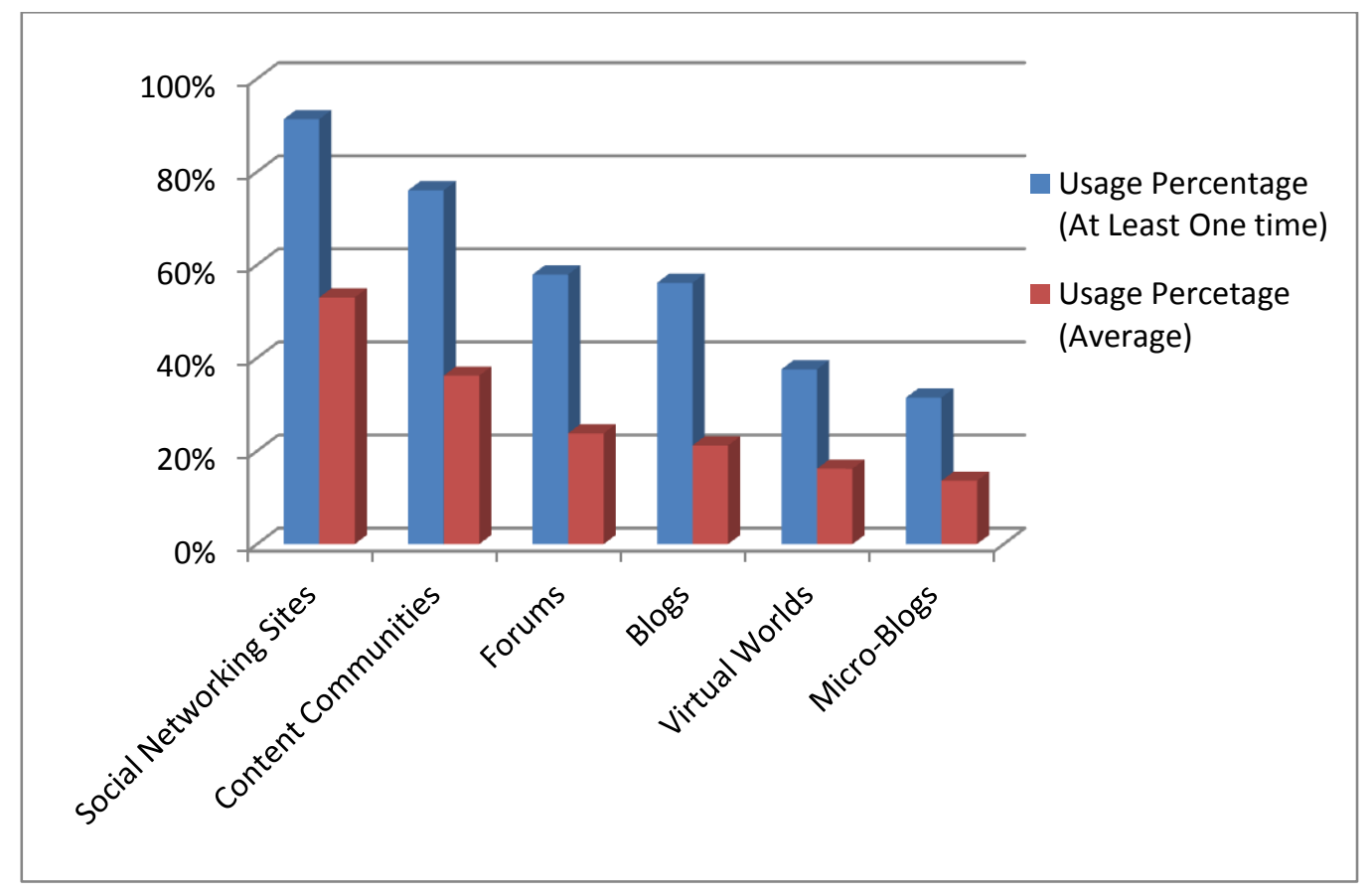

\section{Graph 12: Social media tool preferences}

\subsection{MOTIVATION OF USING SOCIAL MEDIA}

In this section, exploratory factor analysis is conducted which was also used to observe the sub-dimensions of the research variables. Principal Components Analysis (PCA) is the most widely used method in factor analysis (Kurtuluş, 2004). Thus, in this study principal components method is used. Varimax method separates the factors in a 
clearer way (Hair at al, 2010). Therefore, varimax rotation method which maximizes the sum of variances of required loading of the factor matrix is used as a rotation method.

Primarily, all 21 variables in Q3 were implemented in factor analysis and in order to test the Cronbach Alpha Coefficient which assesses the consistency of the scale (Hair at al., 2010) is used. Although the consensus upon the limit for Cronbach Alpha is .70 (Hair at al., 2010), Nunnally (1967) claimed that for preliminary exploratory researches 0.5 may be accepted as minimum level. Cronbach Alpha coefficient of the scale is found as 0.871 which indicates that the scale used for the analysis can be considered as reliable. Furthermore, in order to determine whether the data is appropriate for factor analysis, Kaiser-Meyer-Olkin (KMO) and Bartlett test of sphericity methods were conducted. KMO is a measure for sampling adequacy which can range between 0 and 1 . The closer it is to 1 the higher the adequacy and less than 0.6 is unacceptable (Pett, Lackey and Sullivan, 2003). In addition, Bartlett test of sphericity is a statistical test for the overall significance of all correlations within a correlation matrix and provides statistical significance (Hair at al, 2010, p: 92). In this study, as it is seen in Table-9 Kaiser-Meyer-Olkin sampling appropriateness value is .894 and Bartlett test has significant results (Chi-Square $=5548,362, \mathrm{p}=.000<.05)$, data is appropriate for factor analysis. In addition, there are four factors whose eigenvalues are greater than 1 , and these factors explain $52.083 \%$ of the total variance.

Table 8: The results of KMO and Bartlett tests of Motivations

\begin{tabular}{|l|l|r|}
\hline \multicolumn{3}{|c|}{ KMO and Bartlett's Test } \\
\hline Kaiser-Meyer-Olkin Measure of Sampling Adequacy. &, 894 \\
\hline $\begin{array}{l}\text { Bartlett's Test of } \\
\text { Sphericity }\end{array}$ & Approx. Chi-Square & 5548,362 \\
\cline { 2 - 3 } & df & 210 \\
\cline { 2 - 3 } & Sig. &, 000 \\
\hline
\end{tabular}

After the KMO and Bartlett tests, another important criterion is communality which means total amount of variance and original variable shares with all other variables included in the analysis (Hair at al., 2010). The communality table of all the variables in Q3 is shown in Table-10. 
Table 9: Communalities of the Motivational Variables

\begin{tabular}{|l|r|c|} 
& Initial & Extraction \\
\hline Stay in touch with friends & 1,000 &, 568 \\
Network for work & 1,000 &, 448 \\
Meet new people & 1,000 &, 535 \\
Cheaper Communication & 1,000 &, 336 \\
Express myself & 1,000 &, 644 \\
Keep my friends up to date with my life & 1,000 &, 601 \\
Listen to music & 1,000 &, 523 \\
Play games & 1,000 &, 539 \\
Popularity & 1,000 &, 398 \\
Escapism & 1,000 &, 320 \\
Take on a different personality & 1,000 &, 588 \\
Fill up spare time & 1,000 &, 439 \\
Share content & 1,000 &, 542 \\
Curiosity about others & 1,000 &, 451 \\
Share my opinion & 1,000 &, 601 \\
to get inspired/get ideas & 1,000 &, 472 \\
Research about products & 1,000 &, 578 \\
Read news & 1,000 &, 605 \\
Research on companies & 1,000 &, 710 \\
Complain about products & 1,000 &, 594 \\
Keep updated & 1,000 &, 446 \\
\hline
\end{tabular}

However, in order to have more reliable test results communality value after extraction is expected to be above 0.4 (Lee, 2004). Therefore, first the variable (Escapism) which has the lowest communality value was extracted from the analysis, and factor analysis was reiterated. This process was continued one by one until all the communality values became over 0.4 . As a result, 4 variables (escapism, cheaper communication, to get inspired/get ideas and popularity) extracted from the analysis.

Table-11 indicates the results of KMO and Bartlett Tests after the 4 variables were extracted from the main variable list. These results show that the data is appropriate for the analysis. 
Table 10: The results of KMO and Bartlett Tests of Motivational Variables after Extraction

\begin{tabular}{|l|l|r|}
\hline \multicolumn{3}{|c|}{ KMO and Bartlett's Test } \\
\hline Kaiser-Meyer-Olkin Measure of Sampling Adequacy. &, 871 \\
\hline Bartlett's Test of Sphericity & Approx. Chi-Square & 4425,547 \\
\cline { 2 - 3 } & df & 136 \\
\cline { 2 - 3 } & Sig. &, 000 \\
\hline
\end{tabular}

Table-12 indicates the communalities of the variables after extraction and communality values can also be observes as greater than 0.4 .

Table 11: Communalities for Motivational Variables after Extraction

\begin{tabular}{|l|r|c|}
\hline \multicolumn{1}{|c|}{ Communalities } & Initial & Extraction \\
\hline Stay in touch with friends & 1,000 &, 562 \\
\hline Network for work & 1,000 &, 433 \\
\hline Meet new people & 1,000 &, 602 \\
\hline Express myself & 1,000 &, 616 \\
\hline Keep my friends up to date with my life & 1,000 &, 609 \\
\hline Listen to music & 1,000 &, 592 \\
\hline Play games & 1,000 &, 640 \\
\hline Take on a different personality & 1,000 &, 620 \\
\hline Fill up spare time & 1,000 &, 408 \\
\hline Share content & 1,000 &, 569 \\
\hline Curiosity about others & 1,000 &, 482 \\
\hline Share my opinion & 1,000 &, 595 \\
\hline Research about products & 1,000 &, 543 \\
\hline Read news & 1,000 &, 612 \\
\hline Research on companies & 1,000 &, 728 \\
\hline Complain about products & 1,000 &, 633 \\
\hline Keep updated & 1,000 &, 476 \\
\hline \multicolumn{2}{|c|}{ Extraction Method: Principal Component Analysis } \\
\hline
\end{tabular}

It was found that four factors have Eigen values (a measure of explained variance) greater than 1.0 which is a common criterion for a factor to be useful as it is seen in the Table-13. Here the first factor shows the highest variance which explains 
$20,043 \%$ of the total variance explained. Total four factors explain $57,178 \%$ of the total variance, which is reasonably significant for the study.

Table 12: Total Variance Explained for Motivation Factors

\begin{tabular}{|c|c|c|c|c|c|c|}
\hline \multirow{2}{*}{ Component } & \multicolumn{3}{|c|}{ Initial Eigenvalues } & \multicolumn{3}{c|}{$\begin{array}{c}\text { Rotation Sums of Squared } \\
\text { Loadings }\end{array}$} \\
\cline { 2 - 7 } & Total & $\begin{array}{c}\text { \% of } \\
\text { Variance }\end{array}$ & $\begin{array}{c}\text { Cumulative } \\
\text { \% }\end{array}$ & Total & $\begin{array}{c}\text { \% of } \\
\text { Variance }\end{array}$ & $\begin{array}{c}\text { Cumulative } \\
\text { \% }\end{array}$ \\
\hline 1 & 4,968 & 29,225 & 29,225 & 3,407 & 20,043 & 20,043 \\
\hline 2 & 2,476 & 14,562 & 43,786 & 2,845 & 16,734 & 36,777 \\
\hline 3 & 1,219 & 7,168 & 50,955 & 1,857 & 10,923 & 47,700 \\
\hline 4 & 1,058 & 6,223 & 57,178 & 1,611 & 9,477 & 57,178 \\
\hline 5 &, 888 & 5,224 & 62,402 & & & \\
\hline 6 &, 729 & 4,286 & 66,688 & & & \\
\hline 7 &, 699 & 4,113 & 70,801 & & & \\
\hline 8 &, 656 & 3,862 & 74,663 & & & \\
\hline 9 &, 603 & 3,546 & 78,209 & & & \\
\hline 10 &, 585 & 3,444 & 81,653 & & & \\
\hline 11 &, 544 & 3,198 & 84,850 & & & \\
\hline 12 &, 521 & 3,065 & 87,915 & & & \\
\hline 13 &, 497 & 2,926 & 90,842 & & & \\
\hline 14 &, 457 & 2,690 & 93,532 & & & \\
\hline 15 &, 416 & 2,449 & 95,981 & & & \\
\hline 16 &, 352 & 2,070 & 98,051 & & & \\
\hline 17 &, 331 & 1,949 & 100,000 & & & \\
\hline
\end{tabular}

Table-14 indicates the Rotated Factor Matrix that contains the factor loadings which show the correlation between the original variables and the factors, and the key to understanding the nature of a particular factor. When the sample size is increased the acceptable factor loading level is decreased. For more than 350 sample factor loadings of 0.3 is enough to have significant results (Hair at al., 2010). After 9 iterations the software has sorted the 17 variables into four factors in which each factor consists of those variables having a loading of 0.40 or higher since the sample size is more than 1000. 
Table 13: Rotated Component Matrix for Motivation Factors after extraction

\begin{tabular}{|l|c|c|c|c|}
\hline \multirow{2}{*}{} & \multicolumn{4}{|c|}{ Component } \\
\cline { 2 - 5 } & $\mathbf{1}$ & $\mathbf{2}$ & $\mathbf{3}$ & $\mathbf{4}$ \\
\hline Keep my friends up to date with my life &, 748 & & & \\
Share content &, 719 & & & \\
Express myself &, 705 & & & \\
Share my opinion &, 680 & & & \\
Curiosity about others &, 664 & & & \\
Stay in touch with friends &, 545 & &, 458 & \\
Research on companies & &, 848 & & \\
Complain about products & &, 741 & & \\
Read news & &, 680 & & \\
Research about products & &, 658 & & \\
Network for work & &, 602 & & \\
Keep updated &, 409 &, 457 & & \\
Listen to music & & &, 726 & \\
Play games & & &, 628 &, 491 \\
Fill up spare time & & &, 487 & \\
Take on a different personality & & & &, 751 \\
Meet new people &, 406 & & &, 588 \\
\hline
\end{tabular}

Table-15 indicates the factor names, factor loadings, Cronbach Alpha's, explained variance and the number of factors.

Table 14: Factor Analysis and Reliability for Motivation Factors

\begin{tabular}{|c|c|c|c|c|c|}
\hline & $\begin{array}{c}\text { ITEM } \\
\text { LABELS }\end{array}$ & $\begin{array}{c}\text { FACTOR } \\
\text { LOADINGS }\end{array}$ & $\begin{array}{l}\text { VARIANCE } \\
\text { EXPLAINED }\end{array}$ & $\begin{array}{l}\text { NUMBER } \\
\text { of ITEMS }\end{array}$ & $\begin{array}{c}\text { CRONBACH } \\
\text { ALPHA }\end{array}$ \\
\hline \multicolumn{6}{|c|}{ FACTOR-1 SOCIAL SHARING } \\
\hline V5-6 & $\begin{array}{l}\text { Keep my friends } \\
\text { up to date with } \\
\text { my life }\end{array}$ &, 748 & \multirow{6}{*}{20,043} & \multirow{6}{*}{6} & \multirow{6}{*}{, 820} \\
\hline $\begin{array}{l}\text { V5- } \\
13 \\
\end{array}$ & Share content & ,719 & & & \\
\hline V5-5 & Express myself & ,705 & & & \\
\hline $\begin{array}{l}\text { V5- } \\
15\end{array}$ & Share my opinion & ,680 & & & \\
\hline $\begin{array}{l}\text { V5- } \\
14 \\
\end{array}$ & $\begin{array}{l}\text { Curiosity about } \\
\text { others }\end{array}$ & ,664 & & & \\
\hline V5-1 & $\begin{array}{l}\text { Stay in touch } \\
\text { with friends }\end{array}$ & ,545 & & & \\
\hline
\end{tabular}




\begin{tabular}{|c|c|c|c|c|c|}
\hline \multicolumn{6}{|c|}{ FACTOR-2 INFORMATION } \\
\hline $\begin{array}{l}\text { V5- } \\
19\end{array}$ & $\begin{array}{l}\text { Research on } \\
\text { companies }\end{array}$ & 848 & \multirow{6}{*}{16,734} & \multirow{6}{*}{6} & \multirow{6}{*}{, 774} \\
\hline $\begin{array}{l}\text { V5- } \\
20\end{array}$ & $\begin{array}{l}\text { Complain about } \\
\text { products }\end{array}$ & ,741 & & & \\
\hline $\begin{array}{l}\text { V5- } \\
18\end{array}$ & Read news & ,680 & & & \\
\hline $\begin{array}{l}\text { V5- } \\
17 \\
\end{array}$ & $\begin{array}{l}\text { Research about } \\
\text { products }\end{array}$ & ,658 & & & \\
\hline $\begin{array}{l}\text { V5- } \\
20\end{array}$ & $\begin{array}{l}\text { Network for } \\
\text { work }\end{array}$ & 602 & & & \\
\hline $\begin{array}{l}\text { V5- } \\
21\end{array}$ & Keep updated &, 457 & & & \\
\hline \multicolumn{6}{|c|}{ FACTOR-3 ENTERTAINMENT } \\
\hline V5-7 & Listen to music & ,726 & \multirow{3}{*}{10,923} & \multirow{3}{*}{3} & \multirow{3}{*}{0,581} \\
\hline V5-8 & Play games & 628 & & & \\
\hline $\begin{array}{l}\text { V5- } \\
12\end{array}$ & Fill up spare time & 487 & & & \\
\hline \multicolumn{6}{|c|}{ FACTOR-4 ESCAPISM } \\
\hline $\begin{array}{l}\text { V5- } \\
11\end{array}$ & \begin{tabular}{|l|} 
Take on a \\
different \\
personality
\end{tabular} &, 751 & \multirow[t]{2}{*}{9,477} & \multirow[t]{2}{*}{2} & \multirow[t]{2}{*}{0,545} \\
\hline V5-3 & Meet new people & ,588 & & & \\
\hline
\end{tabular}

\subsubsection{Social Sharing (Factor-1)}

One of the motivation factors of using social media tools is social sharing the following aspects; the status of my friends up to date with my life, share content, express myself, share my opinion, curiosity about others, and stay in touch with friends. Almost all the expressions are related to the sharing life and content and also keeping in touch with friends. In general this factor is called as "Sharing". The Cronbach Alpha value of this factor is 0.82 and this factor explains approximately $20 \%$ of the variance.

\subsubsection{Information (Factor-2)}

Another important motivation factor for the social media users is Information search. The users want to keep update, read news through social media and they search information about the products and companies. The Cronbach Alpha value of this factor is 0.774 and information factor explains $16 \%$ of the total variance. 


\subsubsection{Entertainment (Factor-3)}

Third motivation factor is Entertainment. People listen to music, play online games and they fill up their spare time on social media sites. That's why this factor is called as "Entertainment". The Cronbach Alpha of this factor is 0.581 and it explains the $10,923 \%$ of variance.

\subsubsection{Escapism (Factor-4)}

Some people use social media tools to meet new people and some of them take on different personalities. They are searching for change which is different from their daily lives. Therefore this factor is named "Escapism". The Cronbach Alpha value is 0.545 and the explained variance is $9,477 \%$.

\subsection{USAGE RATE OF SOCIAL MEDIA ACTIVITIES}

Here, it is aimed to reveal the clusters according to usage preferences of social media activities. This section consists of 18 variables. Therefore, in order to simplify the study, a factor analysis is aimed to be conducted before cluster analysis. Consequently the cluster analysis will be conduct based on determined factors. Graph12 presents the means and standard deviations of the dependent variables related to fourth question. According to the Graph, users mostly look at the contents in social media. First five activities related to the contents. The least preferred activity on social media is maintaining a character on virtual world. 


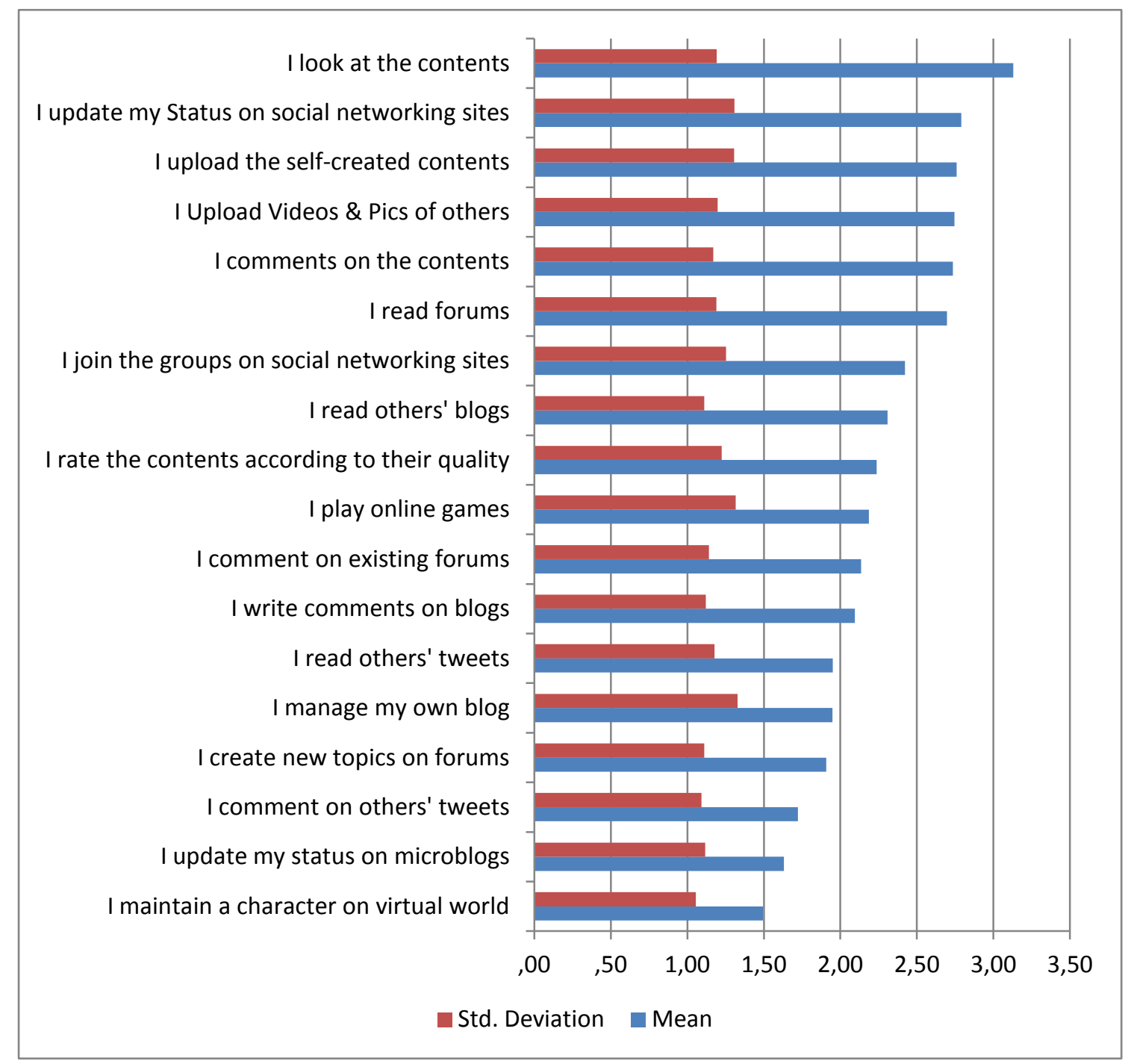

\section{Graph 13: Means and Std. Deviation of the Dependent Variables of Social Media Activity Preferences}

The Cronbach Alpha Coefficient of the scale for the fourth question is 0.918 which means that the scale is very reliable for the analysis. In addition, Table-16 indicates the results of KMO and the Bartlett's Test. The KMO measure of sampling adequacy $(0.910)$ and Bartlett's test for sphericity $(p=.000)$ both indicated that the variable set was appropriate for factor analysis. 
Table 15: The results of KMO and Bartlett Tests of Social Media Activities

\begin{tabular}{|l|l|r|}
\hline \multicolumn{3}{|c|}{ KMO and Bartlett's Test } \\
\hline Kaiser-Meyer-Olkin Measure of Sampling Adequacy. &, 910 \\
\hline Bartlett's Test of Sphericity & Approx. Chi-Square & 8134,376 \\
\cline { 2 - 3 } & df & 153 \\
\cline { 2 - 3 } & Sig. &, 000 \\
\hline
\end{tabular}

In this analysis, there are four factors whose Eigen values are greater than 1.0. After rotation, the first factor explains $23,454 \%$ of the total variance. The four factors, explains $65.851 \%$ of the total variance as it is shown in table-17.

Table 16: Total Variance Explained of the Factors

\begin{tabular}{|c|c|c|c|c|c|c|}
\hline \multirow{2}{*}{ Component } & \multicolumn{3}{|c|}{ Initial Eigenvalues } & \multicolumn{3}{c|}{$\begin{array}{c}\text { Rotation Sums of Squared } \\
\text { Loadings }\end{array}$} \\
\cline { 2 - 7 } & Total & $\begin{array}{c}\text { \% of } \\
\text { Variance }\end{array}$ & $\begin{array}{c}\text { Cumulative } \\
\text { \% }\end{array}$ & Total & $\begin{array}{c}\text { \% of } \\
\text { Variance }\end{array}$ & $\begin{array}{c}\text { Cumulative } \\
\text { \% }\end{array}$ \\
\hline 1 & 7,624 & 42,353 & 42,353 & 4,222 & 23,454 & 23,454 \\
\hline 2 & 1,782 & 9,899 & 52,252 & 3,322 & 18,455 & 41,909 \\
\hline 3 & 1,374 & 7,636 & 59,888 & 2,474 & 13,743 & 55,653 \\
\hline 4 & 1,073 & 5,963 & 65,851 & 1,836 & 10,198 & 65,851 \\
\hline 5 &, 977 & 5,429 & 71,280 & & & \\
\hline 6 &, 663 & 3,683 & 74,963 & & & \\
\hline 7 &, 591 & 3,285 & 78,247 & & & \\
\hline 8 &, 550 & 3,055 & 81,302 & & & \\
\hline 9 &, 501 & 2,781 & 84,084 & & & \\
\hline 10 &, 471 & 2,614 & 86,698 & & & \\
\hline 11 &, 420 & 2,332 & 89,030 & & & \\
\hline 12 &, 357 & 1,981 & 91,011 & & & \\
\hline 13 &, 338 & 1,879 & 92,890 & & & \\
\hline 14 &, 323 & 1,795 & 94,685 & & & \\
\hline 15 &, 298 & 1,657 & 96,341 & & & \\
\hline 16 &, 247 & 1,371 & 97,712 & & & \\
\hline 17 &, 220 & 1,223 & 98,935 & & & \\
\hline 18 &, 192 & 1,065 & 100,000 & & & \\
\hline & & & & & & \\
\hline
\end{tabular}


Table-18 indicates the communalities of all the variables related to preferences of the social media activities. Since there is no communality value below 0.4 , no need to extract the variables.

Table 17: Communalities of the Variables Related to the Social Media Activities

\begin{tabular}{|l|r|r|}
\hline \multicolumn{1}{|c|}{ Activities } & Initial & Extraction \\
\hline I manage my own blog & 1,000 &, 486 \\
I read others' blogs & 1,000 &, 686 \\
I write comments on blogs & 1,000 &, 750 \\
I create new topics on forums & 1,000 &, 661 \\
I comment on existing forums & 1,000 &, 695 \\
I read forums & 1,000 &, 552 \\
I update my Status on social networking sites & 1,000 &, 638 \\
I upload the self-created contents & 1,000 &, 598 \\
I Upload Videos \& Pics of others & 1,000 &, 712 \\
I comments on the contents & 1,000 &, 693 \\
I look at the contents & 1,000 &, 705 \\
I rate the contents according to their quality & 1,000 &, 494 \\
I join the groups on social networking sites & 1,000 &, 564 \\
I update my status on microblogs & 1,000 &, 737 \\
I comment on others' tweets & 1,000 &, 840 \\
I read others' tweets & 1,000 &, 751 \\
I play online games & 1,000 &, 648 \\
I maintain a character on virtual world & 1,000 &, 647 \\
\hline
\end{tabular}

Rotated Component Matrix which is shown in table-19 indicates the factors with the related variables and the factor loadings after six iterations. As it is shown in the table-19, all factor loadings are higher than the 0.5 .

Table 18: Rotated Component Matrix of the Variables Related to the Social Media Activities

\begin{tabular}{|l|c|c|c|c|}
\hline \multicolumn{1}{|c|}{ Activities } & \multicolumn{4}{|c|}{ Component } \\
\cline { 2 - 5 } & $\mathbf{1}$ & $\mathbf{2}$ & $\mathbf{3}$ & $\mathbf{4}$ \\
\hline I look at the contents &, 814 & & & \\
I Upload Videos \& Pics of others &, 812 & & & \\
I comments on the contents &, 781 & & & \\
I update my Status on social networking sites &, 754 & & & \\
I upload the self-created contents &, 713 & & & \\
\hline
\end{tabular}




\begin{tabular}{|l|r|r|r|r|} 
I join the groups on social networking sites &, 636 & & & \\
I rate the contents according to their quality &, 535 & & & \\
I write comments on blogs &, 766 & & \\
I read others' blogs &, 744 & & \\
I comment on existing forums &, 720 & & \\
I create new topics on forums &, 672 & &, 427 \\
I manage my own blog & &, 623 & & \\
I read forums & & &, 841 & \\
I comment on others' tweets & & &, 807 & \\
I read others' tweets & & & &, 797 \\
I update my status on microblogs & & & &, 721 \\
\hline I play online games & & & \\
I maintain a character on virtual world
\end{tabular}

Table-20 indicates the Cronbach Alpha coefficients, Factor Loadings, Explained variance for each factor.

Table 19: Factor Analysis and Reliability for the Variables Related to the Social Media Activities

\begin{tabular}{|c|c|c|c|c|c|}
\hline & ITEM & $\sim$ & 里 & कै & 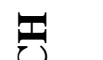 \\
\hline & LABELS & 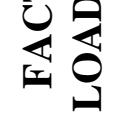 & $\underset{2}{a}$ & $\sum_{\mathbf{Z}}^{\text {党 }}$ & 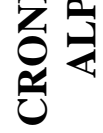 \\
\hline FACT & R-1 Usage of Content Communities and S & S's & & & \\
\hline V4-11 & I look at the contents & 0,814 & & & \\
\hline V4-9 & I Upload Videos \& Pics of others & 0,812 & & & \\
\hline V4-10 & I comments on the contents & 0,781 & & & \\
\hline V4-7 & $\begin{array}{l}\text { I update my Status on social networking } \\
\text { sites }\end{array}$ & 0,754 & 23,45 & 7 & 0.865 \\
\hline V4-8 & I upload the self-created contents & 0,713 & & & \\
\hline V4-13 & I join the groups on social networking sites & 0,636 & & & \\
\hline V4-12 & I rate the contents according to their quality & 0,535 & & & \\
\hline FACT & R-2 Usage of Blogs and Forums & & & & \\
\hline V4-3 & I write comments on blogs & 0,766 & & & \\
\hline V4-2 & I read others' blogs & 0,744 & 8 & 6 & 840 \\
\hline V4-5 & I comment on existing forums & 0,72 & 18,40 & 0 & 0.849 \\
\hline V4-4 & I create new topics on forums & 0,672 & & & \\
\hline
\end{tabular}




\begin{tabular}{|c|c|c|c|c|c|}
\hline V4-1 & I manage my own blog & 0,623 & & & \\
\hline V4-6 & I read forums & 0,584 & & & \\
\hline \multicolumn{6}{|c|}{ FACTOR-3 Usage of Twitter } \\
\hline V4-15 & I comment on others' tweets & 0,841 & \multirow{3}{*}{13,74} & \multirow{3}{*}{3} & \multirow{3}{*}{0.868} \\
\hline V4-16 & I read others' tweets & 0,807 & & & \\
\hline V4-14 & I update my status on microblogs & 0,797 & & & \\
\hline \multicolumn{6}{|c|}{ FACTOR-4 Usage of Virtual Platforms } \\
\hline V4-17 & I play online games & 0,772 & \multirow{2}{*}{10,2} & \multirow{2}{*}{2} & \multirow{2}{*}{0.656} \\
\hline V4-18 & I maintain a character on virtual world & 0,721 & & & \\
\hline
\end{tabular}

\subsubsection{Usage of Content Communities and SNS's (Factor 1)}

The first factor consists of seven variables. The reliability of this factor is (0.865) very high. In addition this factor explains the $23,454 \%$ of total variance. The variables in this factor mostly related to the contents and the activities in social networking sites. Actually on social media it is very hard to separate the content communities and social networking sites. Users can share any content on social networking sites; also they can move shared staff from social networking sites to content community sites. Therefore, since this factor is an integration of content communities and social networking sites, it is called as Usage of Content Communities and Social Networking Sites.

\subsubsection{Usage of Blogs and Forums (Factor 2)}

The second factor is Usage of Blogs and Forums which includes six variables. The Cronbach Alpha Coefficient of this factor is 0.849 which has a very high reliability; this factor also explains the $18,455 \%$ of total variance. This factor includes all the activities related to the forums and blogs. Users in this factor read, contribute and create forum topics and blogs. Since forums and blogs are mostly used for the discussions, information acquisition and exchange, they are called as Debaters. 


\subsubsection{Usage of Twitter (Factor 3)}

Third factor is usage of Twitter which consists of just Micro-blogging activities. In Turkey it is commonly known that just Twitter is preferred as a micro blogging site. Therefore, it can be asserted that this factor just consists of publishing, reading and commenting on tweets. Cronbach Alpha Coefficient is 0.868 and this factor explains the 13,743 of total variance.

\subsubsection{Usage of Virtual Platforms (Factor 4)}

This factor consists of the activities related to the virtual game worlds and social world. That's why it is called Usage of Virtual Platforms. The alpha coefficient of this factor is 0.656 and explained variance is 10.198 .

\subsection{TYPOLOGY OF THE SOCIAL MEDIA USERS}

Cluster analysis is a generic name for a variety of mathematical methods, numbering in the hundreds that can be used to find out which objects in a set are similar (Romesburg, 2004). Hair at al. (2010, p:508) defines cluster analysis as a group of multivariate techniques whose primary purpose is to group objects based on the characteristics they pose. The groups must be relatively homogeneous within themselves and heterogeneous between each other (Mazzocchi, 2008). Cluster analysis has been referred to as Q Analysis, Typology Construction, Classification Analysis, and Numerical Taxonomy (Hair at al., 2010). The reason why it is called by a variety of names is that this method is used by different disciplines such as marketing, astronomy, psychiatry, weather classification, archeology, bioinformatics and genetics (Everitt at al., 2009).

There are 4 stages in order to apply cluster analysis properly as it is seen below (Atbaş, 2008);

- Determining the variables

- Determining the most appropriate measure of distance 
- Selecting the clustering Algorithm, linkage method and determining how many clusters are formed

- Interpreting and naming the clusters

In this study, the variables were determined by applying the factor analysis in which four variables were used for the cluster analysis in the first stage. Then squared Euclidean which is the sum of the squared measure of distance was used as a distance measure. Because, squared Euclidean distance is the recommended measure for the centroid and Ward's Methods of clustering (Hair at al., 2010) therefore in this study Ward's method is planned to be used which will be mentioned at the next stage.

Third stage starts with the selection of the clustering type. There are two main cluster types. The first one is the hierarchical method which is an analytical technique for developing meaningful sub-groups of individuals or objects. This method enables the researcher to classify a sample of individuals or objects into a small number of mutually exclusive groups which are not pre-defined (Grebitus, 2008). This method generates a complete set of cluster solution by doing so, it provides framework to compare any set of clusters and helps in judging how many clusters should be retained (Hair at al., 2010, p.533). On the other hand, in nonhierarchical method the number of clusters is pre-determined by the researcher (Atbaş, 2008). The most common used nonhierarchical method is K-means algorithm which is first introduced by Hartigan in 1975. The operation of this algorithm is as follows: given a fixed number of clusters, assign observations to those clusters so that the means across clusters are as different from each other as possible (Nisbet, Elder and Miner, 2009, p.147).

In this study, a combination of hierarchical and k-means method will be used. While applying hierarchical method it is aimed to use Ward's Method which says that the distance between two clusters is how much the sum of squares will increase when they are merged (Hair at al., 2010) as agglomerative algorithm. Because this method identifies clusters nearly equal shape and size (Grover and Vriens, 2006). 
Table 20: Case Processing Summary

\begin{tabular}{|c|r|r|r|r|r|}
\hline \multicolumn{2}{|c|}{ Valid } & \multicolumn{2}{c|}{ Missing } & \multicolumn{2}{c|}{ Total } \\
\hline $\mathrm{N}$ & Percent & $\mathrm{N}$ & Percent & $\mathrm{N}$ & Percent \\
\hline 830 & 82,9 & 171 & 17,1 & 1001 & 100 \\
\hline \multicolumn{2}{|l|}{ a. Squared Euclidean Distance used } \\
\hline
\end{tabular}

Table-21 indicates the case processing summary. Total 1001 cases used for the hierarchical cluster analysis, but only 830 cases valid for the analysis.

In the hierarchical cluster analysis there are two main methods to determine the cluster numbers. The first and most common used method is analyzing dendrogram which shows how the clusters are combined at each step of the process until all are contained in a single cluster graphically (Hair at al, 2010). However this model is suitable if the sample size is not so large. Therefore, in this study the second method, stopping rule which is a clustering algorithm for determining the final clusters, will be formed. Table-21 indicates the stages, clusters, coefficients, number of clustering after combining, differences in the agglomeration coefficient, and \% change in coefficients. The coefficients indicate how much heterogeneity exists in the cluster solutions. The differences in coefficients show the change in heterogeneity when moving from one stage to another (Hair at al., 2010).

Table 21: Agglomeration Schedule for the Cluster Sample

\begin{tabular}{|c|c|c|c|c|c|c|}
\hline \multirow[b]{2}{*}{ Stage } & \multicolumn{2}{|c|}{ Cluster Combined } & \multirow[b]{2}{*}{ Coefficients } & \multirow{2}{*}{$\begin{array}{l}\text { Number of } \\
\text { Clusters after } \\
\text { Combining }\end{array}$} & \multirow[b]{2}{*}{ Differences } & \multirow{2}{*}{$\begin{array}{l}\text { Proportionate } \\
\text { increase in } \\
\text { Heterogeneity } \\
\text { to Next Stage }\end{array}$} \\
\hline & $\begin{array}{c}\text { Cluster } \\
1 \\
\end{array}$ & $\begin{array}{c}\text { Cluster } \\
2 \\
\end{array}$ & & & & \\
\hline 820 & 12 & 49 & 861,506 & 10 & 49,458 & $5,74 \%$ \\
\hline 821 & 6 & 18 & 910,964 & 9 & 63,770 & $7,00 \%$ \\
\hline 822 & 12 & 60 & 974,734 & 8 & 68,975 & $7,08 \%$ \\
\hline 823 & 1 & 3 & 1043,710 & 7 & 81,406 & $7,80 \%$ \\
\hline 824 & 6 & 14 & 1125,115 & 6 & 136,709 & $12,15 \%$ \\
\hline 825 & 4 & 23 & 1261,824 & 5 & 177,309 & $14,05 \%$ \\
\hline 826 & 12 & 19 & 1439,133 & 4 & 177,333 & $12,32 \%$ \\
\hline 827 & 4 & 6 & 1616,466 & 3 & 420,682 & $26,02 \%$ \\
\hline 828 & 1 & 4 & 2037,147 & 2 & 1097,401 & $53,87 \%$ \\
\hline 829 & 1 & 12 & 3134,548 & 1 & - & - \\
\hline
\end{tabular}


According to the table the largest increase $(53.87 \%)$ is for two clusters. However, according to stopping rule two cluster solutions always show the largest increase. Thus the other stages will be evaluated. Three-cluster solution has the second largest proportion, but in similar studies the cluster numbers are more than 3 . Therefore remained stages will be analyzed. Third largest increase is between the stage 825 and 826 which is approximately $14 \%(1439.133-1261.824 / 1261.824=.1405)$. Therefore five-cluster solution was chosen as stopping point.

After determination of cluster size, K-Means cluster analysis was applied to the sample. Table-22 indicates the average means of the pre-determined factors for each cluster.

Table 22: Final Cluster Centers

\begin{tabular}{|l|r|r|r|r|r|}
\hline & \multicolumn{5}{|c|}{ Cluster } \\
\cline { 2 - 6 } & $\begin{array}{c}\mathbf{1} \\
\text { Sporadics }\end{array}$ & $\begin{array}{c}\mathbf{2} \\
\text { Inactives }\end{array}$ & $\begin{array}{c}\mathbf{3} \\
\text { Advaced } \\
\text { Users }\end{array}$ & $\begin{array}{c}\text { 4 } \\
\text { Entertainment } \\
\text { Users }\end{array}$ & \begin{tabular}{c}
\multicolumn{1}{c|}{$\mathbf{5}$} \\
Debaters
\end{tabular} \\
\hline $\begin{array}{l}\text { Usage_of_Content } \\
\text { Communuties_SNSs }\end{array}$ & 2,97 & 1,66 & 4,17 & 3,02 & 3,30 \\
\hline $\begin{array}{l}\text { Usage_of_Forum_ } \\
\text { Blog }\end{array}$ & 2,13 & 1,46 & 3,66 & 2,62 & 2,78 \\
\hline Usage_of_Twitter & 1,29 & 1,25 & 3,87 & 1,74 & 2,95 \\
\hline $\begin{array}{l}\text { Usage_of_Virtual_Pl } \\
\text { atforms }\end{array}$ & 1,36 & 1,45 & 3,99 & 3,29 & 1,53 \\
\hline
\end{tabular}

In the first cluster there is an average usage of Social networking sites and Content communities and also the members of this cluster rarely use blogs and forums. They don't use Twitter and Virtual platforms, thus this cluster is called "Sporadics". The second cluster consists of the members that nearly none of them use any kind of social media tools therefore it is adequate to name it as "Inactives". The members of the third cluster use almost all the social media tools actively therefore the name of this cluster is given as "Advanced users". The most important characteristics of the forth cluster is the usage rate of the virtual platforms. In this group, members mostly prefer to play online games and have virtual lives. Also they use the content communities, social networking sites in an average level. Since the virtual worlds mostly related to the entertainment, this cluster is called as "Entertainment Users". In the final cluster, 
members use almost every social media tools rather than virtual platforms. The members of this cluster use twitter, forums, blogs, social networking sites and content communities. This cluster is called as "Debaters". As of now, these cluster names will be used for the upcoming analysis.

Table-24 indicates the ANOVA table of the clusters that shows there are significant differences between the clusters based on the factors.

Table 23: ANOVA table of the Clusters

\begin{tabular}{|c|c|c|c|c|c|c|}
\hline & \multicolumn{2}{|c|}{ Cluster } & \multicolumn{2}{|c|}{ Error } & \multirow[b]{2}{*}{$\mathbf{F}$} & \multirow[b]{2}{*}{ Sig. } \\
\hline & $\begin{array}{l}\text { Mean } \\
\text { Square }\end{array}$ & df & $\begin{array}{l}\text { Mean } \\
\text { Square }\end{array}$ & df & & \\
\hline Usage_of_ContentCommunutes_SNSs & 125,128 & 4 & ,327 & 825 & 382,651 & ,000 \\
\hline Usage_of_Forum_Blog & 84,233 & 4 & ,385 & 825 & 219,037 & ,000 \\
\hline Usage_of_Twitter & 143,458 & 4 & ,316 & 825 & 453,386 & ,000 \\
\hline Usage_of_Virtual_Platforms & 151,824 & 4 & ,325 & 825 & 467,552 & ,000 \\
\hline
\end{tabular}

The number of cases for each cluster is given in table-25. According to the table Cluster-1 (Sporadics) has the most cases (277). The case number of Cluster-2 (Inactives) (270) is very close to the Cluster-1. The least cases are at the third cluster (Advanced Users) (61).

Table 24: Number of Cases in Each Cluster

\begin{tabular}{|l|c|c|r|}
\hline \multirow{4}{*}{ Cluster } & Sporadics & 277 & $33 \%$ \\
\cline { 2 - 4 } & Inactives & 270 & $33 \%$ \\
\cline { 2 - 4 } & Advances Users & 61 & $7 \%$ \\
\cline { 2 - 4 } & Entertainment Users & 99 & $12 \%$ \\
\cline { 2 - 4 } & Debaters & 123 & $15 \%$ \\
\hline Valid & & 830 & $100 \%$ \\
\hline Missing & 171 & \\
\hline
\end{tabular}

\subsubsection{The Demographic Characteristics of the Clusters}

Table-26 indicates the demographic characteristics of the clusters. According to the table the demographics features of the clusters are given below. 
Table 25: The demographic characteristics of the clusters

\begin{tabular}{|c|c|c|c|c|c|c|c|c|c|c|c|}
\hline \multirow{3}{*}{ Demographics } & \multicolumn{11}{|c|}{ Clusters } \\
\hline & \multirow{2}{*}{$\begin{array}{c}\% \text { of } \\
\text { Total } \\
\text { Sample }\end{array}$} & \multicolumn{2}{|c|}{ Inactives } & \multicolumn{2}{|c|}{ Sporadics } & \multicolumn{2}{|c|}{\begin{tabular}{|c|} 
Entertainment \\
Users
\end{tabular}} & \multicolumn{2}{|c|}{ Debaters } & \multicolumn{2}{|c|}{$\begin{array}{l}\text { Advanced } \\
\text { Users }\end{array}$} \\
\hline & & Count & $\%$ & Count & $\%$ & Count & $\%$ & Count & $\%$ & Count & $\%$ \\
\hline \multicolumn{12}{|c|}{ Gender } \\
\hline Male & 60,3 & 152 & $56,3 \%$ & 157 & $56,7 \%$ & 84 & $84,8 \%$ & 75 & $61,0 \%$ & 47 & $77,0 \%$ \\
\hline Female & 39,7 & 118 & $43,7 \%$ & 120 & $43,3 \%$ & 15 & $15,2 \%$ & 48 & $39,0 \%$ & 14 & $23,0 \%$ \\
\hline \multicolumn{12}{|c|}{ Age Group } \\
\hline Less than 18 & 28,6 & 50 & $19,1 \%$ & 70 & $26,0 \%$ & 50 & $51,0 \%$ & 24 & $19,8 \%$ & 29 & $49,2 \%$ \\
\hline $18-24$ & 26,1 & 63 & $24,0 \%$ & 70 & $26,0 \%$ & 19 & $19,4 \%$ & 48 & $39,7 \%$ & 17 & $28,8 \%$ \\
\hline $25-34$ & 30,7 & 91 & $34,7 \%$ & 100 & $37,2 \%$ & 21 & $21,4 \%$ & 38 & $31,4 \%$ & 9 & $15,3 \%$ \\
\hline $35-44$ & 10,3 & 40 & $15,3 \%$ & 18 & $6,7 \%$ & 6 & $6,1 \%$ & 10 & $8,3 \%$ & 2 & $3,4 \%$ \\
\hline over 45 & 4,3 & 18 & $6,9 \%$ & 11 & $4,1 \%$ & 2 & $2,0 \%$ & 1 & ,8\% & 2 & $3,4 \%$ \\
\hline \multicolumn{12}{|c|}{ Marital Status } \\
\hline Single & 74,3 & 186 & $68,9 \%$ & 205 & $74,0 \%$ & 84 & $84,8 \%$ & 94 & $76,4 \%$ & 51 & $83,6 \%$ \\
\hline Married & 24,6 & 83 & $30,7 \%$ & 70 & $25,3 \%$ & 14 & $14,1 \%$ & 27 & $22,0 \%$ & 6 & $9,8 \%$ \\
\hline Divorced & 1,1 & 1 & ,4\% & 2 & ,7\% & 1 & $1,0 \%$ & 2 & $1,6 \%$ & 4 & $6,6 \%$ \\
\hline \multicolumn{12}{|c|}{ Total Income } \\
\hline 0-999 TL & 21,9 & 57 & $21,1 \%$ & 55 & $19,9 \%$ & 28 & $28,3 \%$ & 24 & $19,5 \%$ & 17 & $27,9 \%$ \\
\hline 1000-1999 TL & 38,8 & 101 & $37,4 \%$ & 110 & $39,7 \%$ & 39 & $39,4 \%$ & 47 & $38,2 \%$ & 20 & $32,8 \%$ \\
\hline 2000-2999 TL & 18,7 & 50 & $18,5 \%$ & 50 & $18,1 \%$ & 14 & $14,1 \%$ & 22 & $17,9 \%$ & 16 & $26,2 \%$ \\
\hline 3000-3999 TL & 10,7 & 32 & $11,9 \%$ & 35 & $12,6 \%$ & 10 & $10,1 \%$ & 15 & $12,2 \%$ & 2 & $3,3 \%$ \\
\hline $4000-4999 \mathrm{TL}$ & 3,6 & 10 & $3,7 \%$ & 12 & $4,3 \%$ & 3 & $3,0 \%$ & 2 & $1,6 \%$ & 3 & $4,9 \%$ \\
\hline 5000-5999 TL & 2,4 & 7 & $2,6 \%$ & 5 & $1,8 \%$ & 2 & $2,0 \%$ & 7 & $5,7 \%$ & 1 & $1,6 \%$ \\
\hline 6000-6999 TL & 1,4 & 5 & $1,9 \%$ & 4 & $1,4 \%$ & 1 & $1,0 \%$ & 1 & ,8\% & 1 & $1,6 \%$ \\
\hline 7000-7999 TL & 9 & 1 & ,4\% & 4 & $1,4 \%$ & 1 & $1,0 \%$ & 1 & $8 \%$ & 0 &, $0 \%$ \\
\hline $8000+$ & 1,7 & 7 & $2,6 \%$ & 2 & ,7\% & 1 & $1,0 \%$ & 4 & $3,3 \%$ & 1 & $1,6 \%$ \\
\hline \multicolumn{12}{|c|}{ Education } \\
\hline $\begin{array}{l}\text { Elementary } \\
\text { School }\end{array}$ & 3,4 & 11 & $4,1 \%$ & 6 & $2,2 \%$ & 3 & $3,0 \%$ & 6 & $4,9 \%$ & 2 & $3,3 \%$ \\
\hline High School & 41,7 & 92 & $34,1 \%$ & 105 & $37,9 \%$ & 61 & $61,6 \%$ & 39 & $31,7 \%$ & 40 & $65,6 \%$ \\
\hline $\begin{array}{l}\text { Associate } \\
\text { Degree }\end{array}$ & 12,3 & 38 & $14,1 \%$ & 33 & $11,9 \%$ & 10 & $10,1 \%$ & 14 & $11,4 \%$ & 4 & $6,6 \%$ \\
\hline Undergraduate & 31,3 & 90 & $33,3 \%$ & 93 & $33,6 \%$ & 19 & $19,2 \%$ & 46 & $37,4 \%$ & 11 & $18,0 \%$ \\
\hline $\begin{array}{l}\text { Graduate / } \\
\text { Doctorate }\end{array}$ & 11,3 & 39 & $14,4 \%$ & 40 & $14,4 \%$ & 6 & $6,1 \%$ & 18 & $14,6 \%$ & 4 & $6,6 \%$ \\
\hline \multicolumn{12}{|c|}{ Occupation } \\
\hline Unemployed & 7,1 & 29 & $10,7 \%$ & 17 & $6,1 \%$ & 3 & $3,0 \%$ & 10 & $8,1 \%$ & 1 & $1,6 \%$ \\
\hline Farmer &, 1 & 0 &, $0 \%$ & 0 &, $0 \%$ & 0 &, $0 \%$ & 1 & ,8\% & 0 &, $0 \%$ \\
\hline Retired & 8 & 2 & ,7\% & 1 & ,4\% & 1 & $1,0 \%$ & 0 & ,0\% & 1 & $1,6 \%$ \\
\hline $\begin{array}{l}\text { Blue-Collar } \\
\text { Worker }\end{array}$ & 2,9 & 9 & $3,3 \%$ & 5 & $1,8 \%$ & 1 & $1,0 \%$ & 7 & $5,7 \%$ & 2 & $3,3 \%$ \\
\hline Civil Servant & 20,5 & 69 & $25,6 \%$ & 54 & $19,5 \%$ & 12 & $12,1 \%$ & 22 & $17,9 \%$ & 7 & $11,5 \%$ \\
\hline Student & 48,9 & 109 & $40,4 \%$ & 136 & $49,1 \%$ & 67 & $67,7 \%$ & 53 & $43,1 \%$ & 40 & $65,6 \%$ \\
\hline Self-Employed & 3,2 & 12 & $4,4 \%$ & 9 & $3,2 \%$ & 3 & $3,0 \%$ & 4 & $3,3 \%$ & 1 & $1,6 \%$ \\
\hline Manager & 2,3 & 4 & $1,5 \%$ & 10 & $3,6 \%$ & 1 & $1,0 \%$ & 3 & $2,4 \%$ & 2 & $3,3 \%$ \\
\hline Other & 14,3 & 36 & $13,3 \%$ & 45 & $16,2 \%$ & 11 & $11,1 \%$ & 23 & $18,7 \%$ & 7 & $11,5 \%$ \\
\hline
\end{tabular}

Table-27 indicates Chi-Square test results of the demographic differences between the clusters. According to the results, there are significant differences between 
the demographics of Gender, Education, Occupation, Marital Status, and Age Groups and the clusters. Total income and the clusters are independent variables since the significance is over 0.05 .

Table 26: Chi-Square Test Results

\begin{tabular}{|l|l|l|r|r|}
\hline \multicolumn{2}{|c|}{ Demographics } & Value & \multicolumn{1}{c|}{ df } & $\begin{array}{c}\text { Asymp. } \\
\text { Sig. (2- } \\
\text { sided) }\end{array}$ \\
\hline Gender & Pearson Chi-Square & $34,929^{\mathrm{a}}$ & 4 &, 000 \\
\hline Total Income & Pearson Chi-Square & $27,031^{\mathrm{a}}$ & 32 & 0,716 \\
\hline Education & Pearson Chi-Square & $48,304^{\mathrm{a}}$ & 16 &, 000 \\
\hline Occupation & Pearson Chi-Square & $58,190^{\mathrm{a}}$ & 32 & 0,003 \\
\hline Marital Status & Pearson Chi-Square & $34,674^{\mathrm{a}}$ & 8 &, 000 \\
\hline Age Groups & Pearson Chi-Square & $85,224^{\mathrm{a}}$ & 16 &, 000 \\
\hline
\end{tabular}

\subsubsection{Inactives}

Although the percentage of the males is higher than the females, the percentage of females in this group is higher than the female percentage of all samples. Therefore it is possible to say that this is a female dominant group. In addition, if the percentage of age groups for Inactives and the whole sample is compared, it is obvious that there is a direct proportion between them, namely the older the age, the more tendency to be inactive. In addition, married people are more inactive in social media. The income and education levels of this cluster are very parallel with the whole sample. The percentage of civil servant in this cluster has increased, while the student's decrease.

\subsubsection{Sporadics}

As it is seen in the Inactives, in this group the percentage of females is higher than the whole sample percentage. This group mostly consists of the people between the ages of 25-34. The percentages of marital status, income, education, and occupation in Socializers group do not differ from the whole sample. 


\subsubsection{Entertainment Users}

Almost this entire group is formed by single males ( $85 \%)$ aged less than 18 . In addition entertainment users generally have low income level and mostly high school students.

\subsubsection{Debaters}

There is nearly no gender, marital status and income difference if this group is compared with the whole sample. The member's average age is between 18 and 24 and they are graduated from university or graduate and doctorate students.

\subsubsection{Advanced Users}

Like Entertainment group, this group has mostly male members. They are single, their age is less than 18, and they have low income. More than $65 \%$ of this group consists of high school students.

\subsubsection{The Nexus between Time Spend on the Internet and the Clusters}

The distribution of average time that the users spend on the Internet based on the clusters is given in Graph-13 and Graph-14. As it is expected, the Inactives spend less time on the Internet. However, on weekends they spend more time on the Internet. Sporadics do not spend much time on the Internet. On weekdays most of them spend less than an hour on the Internet, while 2-3 hour on the weekends. Entertainment users mostly spend 0-3 hours on weekdays and 2-7 hours during weekends. Debaters connect to the Internet with an average of 2-3 hours on weekdays and between 2-7 hours on the weekends. The average time of the Advanced Users on the Internet is nearly parallel with the debaters on weekdays, whereas on weekends they spend more time on the Internet. 


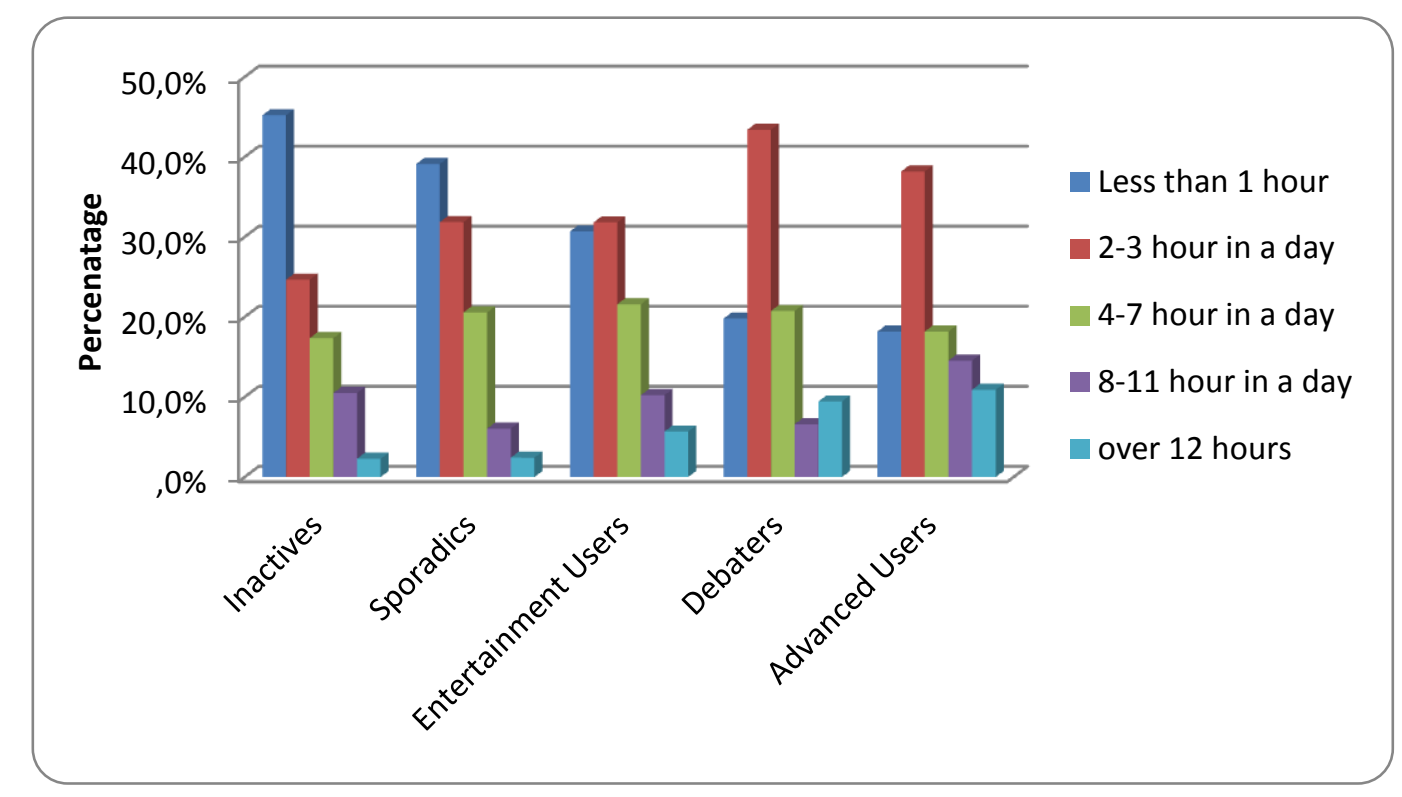

Graph 14: Average Internet Usage on Weekdays based on Clusters

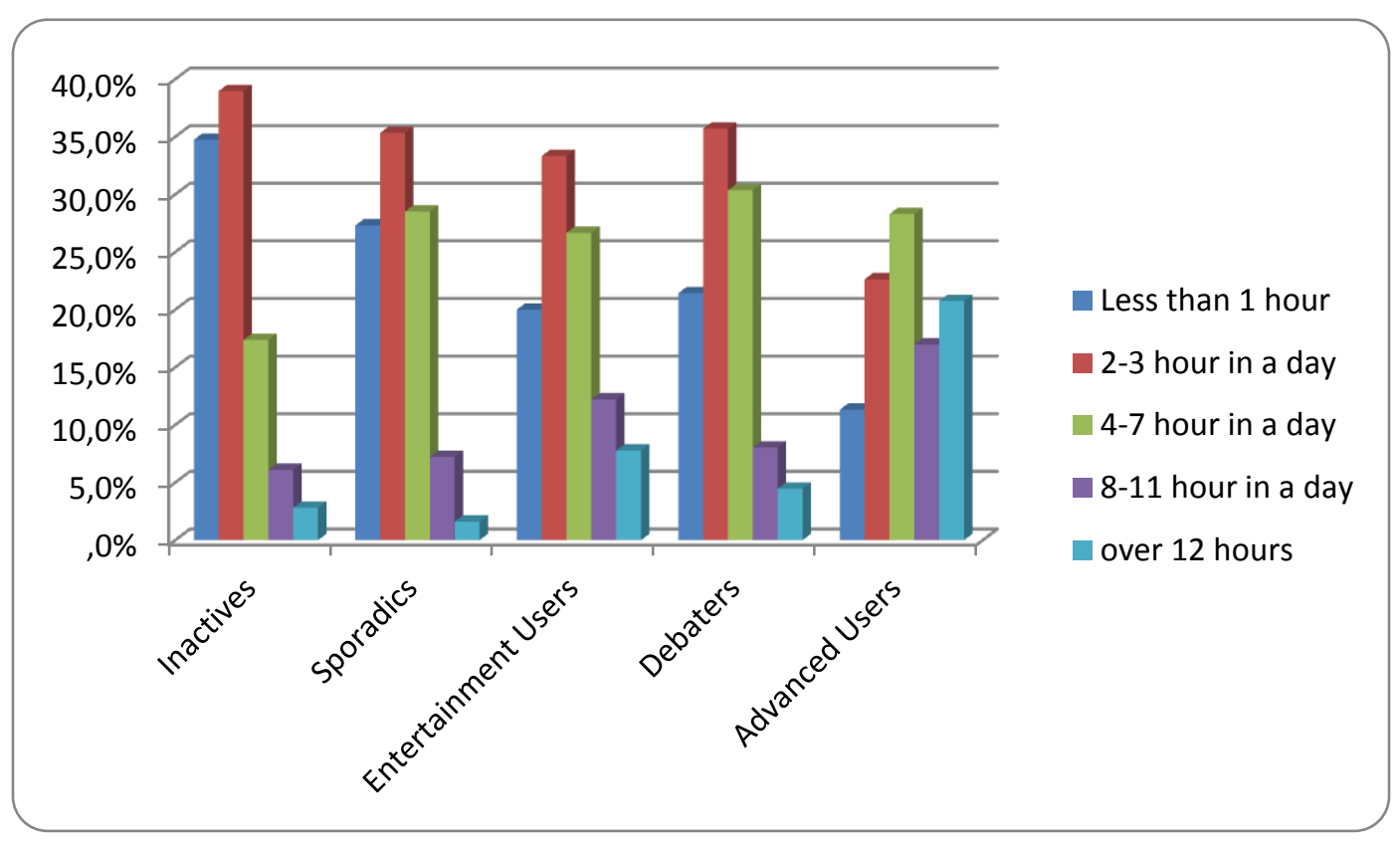

Graph 15: Average Internet Usage on Weekends based on Clusters 
8.4.3. The Nexus between Social Media Usage Motivations and the Clusters

In this section the relationship between the motivation factors of using social media and the clusters are analyzed. In order to find out whether there is a significant difference between the clusters based on motivation factors or not, One-Way ANOVA test is conducted. The results are given in Table-28. According to the test results, there is a significant difference between the clusters in terms of the all motivation factors to use social media which are sharing, information, entertainment, and escape.

Table 27: ANOVA Table of the relationship between the Clusters and Motivation Factors

\begin{tabular}{|l|l|r|r|r|r|r|}
\hline & & $\begin{array}{c}\text { Sum of } \\
\text { Squares }\end{array}$ & \multicolumn{1}{c|}{ df } & $\begin{array}{c}\text { Mean } \\
\text { Square }\end{array}$ & \multicolumn{1}{c|}{ F } & Sig. \\
\hline \multirow{4}{*}{ Social Sharing } & Between Groups & 240,988 & 4 & 60,247 & 117,188 &, 000 \\
\cline { 2 - 8 } & Within Groups & 410,255 & 798 &, 514 & & \\
\cline { 2 - 8 } Information & Total & 651,243 & 802 & & & \\
\hline & Between Groups & 59,992 & 4 & 14,998 & 25,086 &, 000 \\
\cline { 2 - 8 } & Within Groups & 472,324 & 790 &, 598 & & \\
\cline { 2 - 8 } & Total & 532,316 & 794 & & & \\
\hline \multirow{4}{*}{ Encape } & Between Groups & 181,923 & 4 & 45,481 & 74,491 &, 000 \\
\cline { 2 - 8 } & Within Groups & 495,162 & 811 &, 611 & & \\
\cline { 2 - 8 } & Total & 677,084 & 815 & & & \\
\hline & Between Groups & 167,049 & 4 & 41,762 & 67,033 &, 000 \\
\cline { 2 - 8 } & Within Groups & 510,247 & 819 &, 623 & & \\
\cline { 2 - 8 } & Total & 677,296 & 823 & & & \\
\hline
\end{tabular}

In order to reveal how the factors differ between the clusters Scheffe test was conducted. The results are given in Table-29. 
Table 28: Scheffe Test Results for the Sharing Factor

\begin{tabular}{|l|r|r|r|r|}
\hline \multicolumn{5}{|c|}{ Scheffe } \\
\hline & & \multicolumn{3}{|c|}{ Subset for alpha = 0.05 } \\
\cline { 3 - 5 } Cluster Number of Case & $\mathbf{N}$ & $\mathbf{1}$ & $\mathbf{2}$ & $\mathbf{3}$ \\
\hline Inactives & 259 & 2,0573 & & \\
\hline Sporadics & 272 & & 2,9308 & \\
\hline Entertainment Users & 95 & & 2,9772 & \\
\hline Debaters & 118 & & 3,1836 & \\
\hline Advanced Users & 59 & & & 3,9209 \\
\hline Sig. & & 1,000 &, 129 & 1,000 \\
\hline
\end{tabular}

According to the Scheffe test result for the sharing factor which is shown in Table-29, Inactives do not use the social media for the purpose of sharing. Sporadics, entertainment users, and debaters use the social media for sharing at a medium level whereas advanced users most commonly use the social media for the sharing.

Table 29: Scheffe Test Results for the Information Factor

\begin{tabular}{|l|r|r|r|r|r|}
\hline \multicolumn{7}{|c|}{ Scheffe } \\
\hline & \multicolumn{1}{|c|}{ Subset for alpha $=\mathbf{0 . 0 5}$} \\
\cline { 5 - 7 } Cluster Number of Case & \multicolumn{1}{c|}{$\mathbf{N}$} & $\mathbf{1}$ & $\mathbf{2}$ & $\mathbf{3}$ & $\mathbf{4}$ \\
\hline Inactives & 255 & 2,6105 & & & \\
\hline Entertainment Users & 96 & 2,7378 & 2,7378 & & \\
\hline Sporadics & 268 & & 2,9391 & 2,9391 & \\
\hline Debaters & 117 & & & 3,1838 & \\
\hline Advanced Users & 59 & & & & 3,5678 \\
\hline Sig. & &, 816 &, 422 &, 220 & 1,000 \\
\hline
\end{tabular}

Table-30 indicates that inactives and entertainment users do not aim to get information through social media. Sporadics sometimes use social media to be informed. Debaters and advanced users use the social media for the motivation of getting information over the average. 
Table 30: Scheffe Test Results for the Entertainment Factor

\begin{tabular}{|l|r|r|r|r|r|}
\hline \multicolumn{7}{|c|}{ Scheffe } \\
\hline \multirow{2}{*}{ Cluster Number of Case } & \multicolumn{1}{|c|}{$\mathrm{N}$} & 1 & 2 & 3 & 4 \\
\cline { 5 - 7 } & 264 & 2,4886 & & & \\
\hline Inactives & 276 & & 3,0012 & & \\
\hline Sporadics & 121 & & 3,1240 & & \\
\hline Debaters & 96 & & & 3,5903 & \\
\hline Entertainment Users & 59 & & & & 4,1469 \\
\hline Advanced Users & & 1,000 &, 838 & 1,000 & 1,000 \\
\hline Sig. & & & & &
\end{tabular}

Table-31 indicates that the Inactives do not use social media for entertainment. Sporadics and debaters sometimes use social media to enjoy. One of the most expected results is that the entertainment users use social media for the purpose of entertainment.

Table 31: Scheffe Test Results for the Escape Factor

\begin{tabular}{|l|r|r|r|r|r|}
\hline \multicolumn{7}{|c|}{ Scheffe } \\
\hline & & \multicolumn{5}{|c|}{ Subset for alpha = 0.05 } \\
\cline { 4 - 6 } Cluster Number of Case & $\mathbf{N}$ & $\mathbf{1}$ & $\mathbf{2}$ & $\mathbf{3}$ & $\mathbf{4}$ \\
\hline Inactives & 266 & 1,3853 & & & \\
\hline Sporadics & 276 & 1,6304 & & & \\
\hline Debaters & 123 & & 1,9797 & & \\
\hline Entertainment Users & 98 & & & 2,3827 & \\
\hline Advanced Users & 61 & & & & 2,9180 \\
\hline Sig. & &, 222 & 1,000 & 1,000 & 1,000 \\
\hline
\end{tabular}

As it is seen in the previous 3 Scheffe tests, inactives are the least motivated group, while the advanced users are the most motivated one. Sporadics do not want to escape, because they want to interact with their friends. Entertainment users and the advanced users use social media in an average rate for the escaping the real life.

\subsubsection{The Nexus between the Content Categories and the Clusters}

In this study the respondents were asked what kind of contents they prefer to share on social media. The results are given in Table-33. According to table the social 
media users mostly prefer to share music videos. Other shared content types are funny, instructional, technological, extraordinary, Movie \& TV, and sport. The least shared content types are Cars, Celebrities, Cartoons, and Advertisements. In addition, Table-33 indicates the relationship between the share content types and the Clusters. As it is expected, Inactives is the group that shares all the contents less than the average. However, almost all the content preferences are parallel with the average mean of the whole sample. Sporadics' preferences are very similar to the whole sample too. Entertainment users mostly prefer to share $\mathrm{m} \quad$ usic, funny and gaming contents. Especially there is a big difference $(45 \%)$ between the mean of the entertainment users and whole sample in terms of gaming. On the other hand, debaters do not prefer to share game related content. They mostly share music, funny, technological, extraordinary, and instructional contents. The advanced users share all the content categories more than the average (the minimum mean (Politics) is $>3.09$ ).

Table 32:The relationship between the Content Categories and the Clusters

\begin{tabular}{|c|c|c|c|c|c|c|}
\hline Categories & 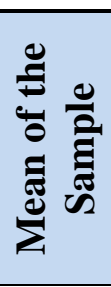 & 芑 & 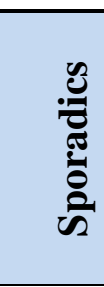 & 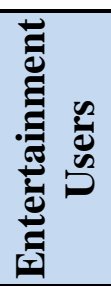 & 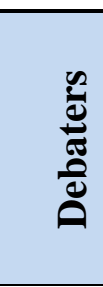 & 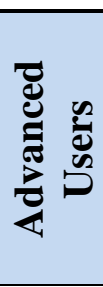 \\
\hline Music & 3,63 & 2,89 & 3,79 & 3,84 & 3,97 & 4,43 \\
\hline Funny & 3,42 & 2,77 & 3,50 & 3,59 & 3,77 & 4,36 \\
\hline Instructional videos & 3,23 & 2,80 & 3,37 & 3,22 & 3,46 & 3,60 \\
\hline Technological & 3,17 & 2,65 & 3,10 & 3,44 & 3,65 & 4,31 \\
\hline Extraordinary & 3,08 & 2,31 & 3,22 & 3,13 & 3,64 & 4,00 \\
\hline Movie/TV & 3,05 & 2,59 & 2,99 & 3,20 & 3,43 & 3,93 \\
\hline Sport & 3,02 & 2,50 & 2,89 & 3,40 & 3,36 & 4,31 \\
\hline Art & 2,76 & 2,25 & 2,78 & 2,82 & 3,16 & 3,56 \\
\hline Romantic & 2,69 & 2,04 & 2,77 & 2,87 & 3,02 & 3,49 \\
\hline Review of products & 2,64 & 2,24 & 2,57 & 2,76 & 3,05 & 3,73 \\
\hline Documentaries & 2,51 & 2,22 & 2,37 & 2,67 & 2,78 & 3,11 \\
\hline Travel & 2,50 & 2,02 & 2,45 & 2,74 & 2,76 & 3,42 \\
\hline Tragic events & 2,48 & 1,85 & 2,54 & 2,81 & 2,80 & 3,12 \\
\hline Animals & 2,44 & 2,04 & 2,32 & 2,79 & 2,77 & 3,26 \\
\hline Gaming & 2,41 & 1,94 & 2,14 & 3,51 & 2,13 & 3,97 \\
\hline Politics & 2,39 & 2,17 & 2,42 & 2,26 & 2,57 & 3,09 \\
\hline
\end{tabular}




\begin{tabular}{|l|l|l|l|l|l|l|} 
Self contents & 2,38 & 1,79 & 2,44 & 2,60 & 2,73 & 3,54 \\
\hline Horror & 2,36 & 1,82 & 2,18 & 2,91 & 2,63 & 3,47 \\
\hline Cars & 2,31 & 1,90 & 2,09 & 2,71 & 2,44 & 3,42 \\
\hline Celebrities & 2,31 & 1,82 & 2,24 & 2,41 & 2,54 & 3,69 \\
\hline Cartoons/Animations & 2,27 & 1,91 & 2,16 & 2,47 & 2,49 & 3,10 \\
\hline Advertisements & 2,05 & 1,73 & 1,94 & 2,16 & 2,41 & 3,15 \\
\hline
\end{tabular}

8.4.5. The Nexus between the Following Companies on Social Media and the Clusters

In this section the relation between the following companies on social media and the clusters are analyzed through Chi-Square tests. As it is seen in Table-34 there is significant difference between the clusters and the following companies on social media.

Table 33:Chi-Square test of the following companies on Social Media

\begin{tabular}{|l|r|r|r|}
\hline & \multicolumn{1}{|c|}{ Value } & \multicolumn{1}{c|}{ df } & \multicolumn{2}{c|}{$\begin{array}{c}\text { Asymp. Sig. } \\
\text { (2-sided) }\end{array}$} \\
\hline Pearson Chi-Square & $22,460^{\mathrm{a}}$ & 4 &, 000 \\
\hline Likelihood Ratio & 22,183 & 4 &, 000 \\
\hline Linear-by-Linear Association & 8,489 & 1 &, 004 \\
\hline N of Valid Cases & 822 & & \\
\hline
\end{tabular}

In addition, the percentage of following companies for each cluster is given in Graph-15. According to the Graph only $27.3 \%$ of the Inactives follow companies on social media. Approximately $35 \%$ of the Sporadics and Entertainment users follow companies on social media, whereas nearly half of the Debaters and Advanced Users follow companies on social media. Therefore it can be propounded that companies should mostly focus on the debaters and the advanced users. 


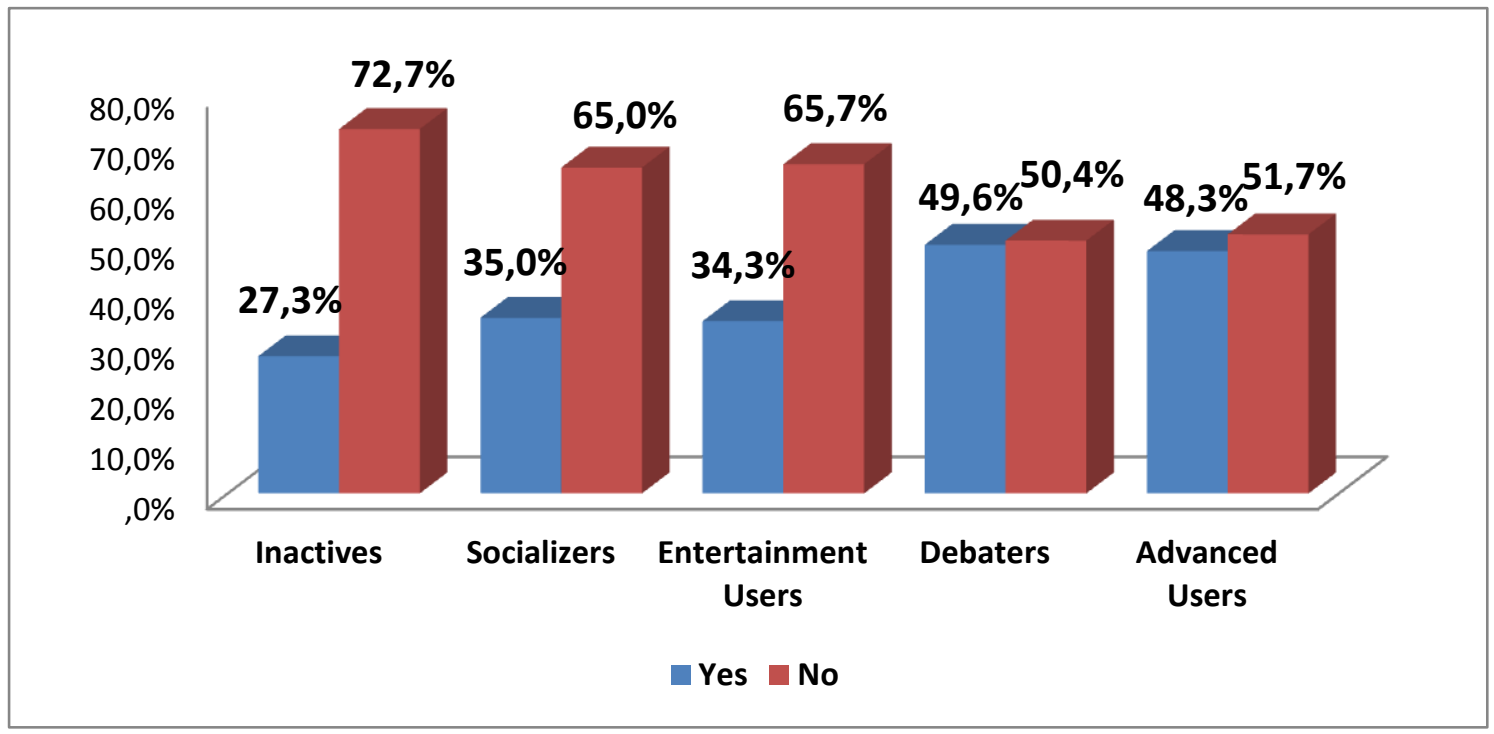

Graph 16: The relationship between Following Companies on Social Media and the Clusters 


\section{CONCLUSION}

This study aims to explore social media usage in Turkey and group the users with regard to their behavior on social media, and profile each group according to demographic affinities and content preferences. Another substantial aim of the study is to reveal the user motivations of social media tools. Since there is no previous research conducted on social media typology in Turkey, the fourth country on Facebook with regard to number of users, with $45 \%$ Internet penetration, this study is timely and contributes both to theory and practice. The study extended the social media user typology research by incorporating a country that is an emerging market and is expected to deviate from the typology put forward for the advanced nations because of its unique characteristics. There are various implications of the findings for practitioners, who target social media users in Turkey with their campaigns.

This study is inspired by Forrester Research Company's Social Technographic Model which is aimed to identify and profile the characteristics and behaviors of consumers into groups. The initial Forrester's Technographic Model in 2006 assumed that there were six clusters related to social media usage. However, with the increasing number of users and new tools, the Forrester Company increased the number of its clusters to seven in 2010. The final clusters were named as Creators, Conversationalists, Critics, Collectors, Joiners, Spectators and Inactives. The clusters were formed according to their level of contribution and interaction, an activity based criteria such as reading, contributing, or creating, on each social media platform. For example, Critics Post comment on blogs, forums, social networking sites and content communities or Spectators just read tweets, reviews, forums, blogs, watch videos. When a similar clustering was done in Turkey based on the activities performed, the criteria in clustering deviated from the Forrester Model and the number of clusters decreased to five; named as Inactives, Sporadics, Entertainment Users, Debaters, and Advanced Users. Inactives are the group of people who do not use any social media tools. This group mostly consists of females, over 35 years old, married people. Sporadics are people that use social networking sites and content communities moderately, and also use blogs and forums below the average. They do not use Micro-blogs and Virtual worlds and games on social media. Since one third of the internet users belong to that 
group, the demographic of the Sporadics is very important. Sporadics are mostly females, aged between 25 and 34 and has high education levels. The third group is the Entertainment Users, who mostly prefer to play online games and use social networking sites and Content Communities. Entertainment users mostly comprise of single, male, high school students aged less than 18. Debaters make up fifteen percent of the Turkish Internet Users who use almost every tool in an average level on social media, but the virtual games and worlds. This group consists of undergraduate and graduate students aged 18-24. Advanced users, who are mostly single, male, high school students aged less than 18, are most influential people who create content and contribute to every tool on social media. Although they are the most desired target by the managers, just $7 \%$ of the Turkish Internet users are included in this group.

The social media user clusters in Turkey are formed based on the type of social media tool that is preferred and used rather than the consumer's level of contribution to each media tool. For example, if a user is member of Twitter, he/she use almost every activity provided by the company such as posting a new Tweet, reading and commenting on others' tweets or if a user is a member of any forum, he/she creates new topics, reads and also makes comments on existing topics. Thus, in the Turkish context, it is seen that people choose their medium, and prefer to be active on it by utilizing every activity rather than diversifying their social media and contribution. However, the clusters under the Social Technographic Model are different from each other based on their level of involvement on each social media tool rather their specific social media tool preference. If the clusters of Social Technographic Model and this study compared to each other, only Advanced Users (Creators) and Inactives have similar characteristics. According to the Forresters' report the percentage of Creators, which has similar characteristics with Advanced Users, is $24 \%$. However in this Study the percentage of Advanced Users is just $7 \%$ which means that social media users is not so active to create new contents. On the other hand, the percentage of Inactives is $17 \%$ in according to the results of the Forrester's Report and the findings of this study indicated that it is $33 \%$ in Turkey. This study indicates that Turkey stands one step behind the U.S. and Europe in terms of active social media usage. 
Another contribution of the study was bringing about the motivation factors for using social media. The study results also indicated that in Turkey there are four motivation factors (Social Sharing, Information, Entertainment and Escapism), which are extracted originally from seventeen variables in the extant literature about motivations to use social media. The results are parallel with the previous researches Dunne, Lawyor and Rowley (2010); Urista, Dong and Day (2009); Haridakis and Hanson (2009); Sheldon (2008); Barker (2009); Raache and Raache (2008) which indicated that users are motivated to use social media tools for the purpose of Entertainment, staying in touch, passing time and getting information about the products and companies. The study also statistically supported Uses and Gratification Theory which says that the same medium may be used by different people to satisfy different psychological and social needs. For example, the Advanced users are motivated by all four factors to use social media, whereas Inactives by none. Both Debaters and Entertainment users use social media tools for social sharing motivation. Entertainment Users also use social media for escaping and entertaining themselves. Debaters, on the other hand, use for seeking information. Finally, Sporadics use social media for social sharing, entertainment and information seeking, but at a moderate rate.

In this study, content preferences of social media users were also analyzed the results revealed that consumers in Turkey and abroad have similar motivations to use social media and prefer to view and share similar content categories on this platform. The results indicated that Music videos, when one looks at the world statistics on YouTube, it is seen that eight of the ten all time most viewed videos are music videos and each of these eight videos have been watched more than three hundred millions times (YouTube, 2011). Other most preferred video categories are funny, instructional, technological and extraordinary videos. The two of the 10 most viewed videos on YouTube are funny videos that these two videos have been viewed over seven hundred millions times. Horrors, cars, celebrities, animations and advertisements are the least attractive content categories on social media. 


\section{Implications of the Study}

\section{Implications for the Practitioners}

This study has several important implications for the practitioners. As it is stated in the literature part, social media is an up-to-date and emerging issue for the marketers. Social media provides several advantages to the marketers such as cost efficiency, ability to reach the current and potential customers smoothly, and get instant feedback from them. In order to maintain a sound relationship and prevent the violation of brands' and companies' image on social media, the marketers should know the online users' habits, preferences, and behaviors well. In this context, this study provides very valuable information for the marketers to generate reformer strategies to manage the online reputation of their companies and brands especially in three aspects. They are "Which platforms are to be selected on social media to engage in target customers", " Which activities are preferred by the target customers on social media", and "What kind of contents do the target customers prefer to use on social media". Concerning the first aspect, on the aggregate level, the users in Turkey mostly prefer Social Networking Sites and content communities on social media; secondly, they prefer Forums and Blogs; thirdly, they use micro-blogs and Virtual platforms. Managers who want to run campaigns to reach consumers, effectively and efficiently on social media in Turkey are therefore, advised to make use of Facebook and Youtube. Furthermore, they may use the cluster analysis results of this research and locate to which cluster group their specific target market falls into and run their campaigns according to their social media preferences. For example, if a marketer targets male, aged less than 18 and high school student customers, it is strongly recommended for them to focus on online games and form the strategies related to the games. On the other hand, older aged, married and female people generally do not prefer to use any social media tools. Therefore, marketers should use traditional promotion strategies in order to reach the related customers. Additionally, since the companies can not intervene to the content on social media directly, they should reach and affect the advanced users who create and manage the contents. Findings disclosed that advanced users are mostly males, young, single, middle-income, university and high school students. These people create, share and read contents on every tools of social media. 
Regarding the content preferences of social media consumers, this study indicates that mostly music, Funny, Instructional, Technological, Extraordinary and Sports related contents are shared on social media. The types of the contents which are preferred to be shared, commented, looked up, rated by social media users is very important for the marketers in the context of viral marketing. In this regard, marketers should focus on music and fun as a theme while forming their viral marketing strategies; so that their message may reach more people effectively.

Since the classification of social media users is not so easy for the marketing managers, some research and consulting firms may provide a social media user report which has a user friendly interface that companies mark the target population demographic specifications and get social media usage preferences of this group, then form their social media marketing strategies considering the result of the report. In this context, an interactive report interface may be structured based on the results of the study and managers in Turkey may make queries by entering the demographics of their target population and reveal their social media usage preferences.

\section{Implications for the Academics}

In terms of the implications for academicians, this study offers a detailed analysis not only for social media, its history and tools but also for the effects of social media on consumer behavior and marketing. First of all, in the literature there is no scientifically tested scale available for researchers to conduct cluster analysis of social media usage. Our social media typology scale was constructed based on the literature, and statistical results indicated that the scale is reliable and generalizable. Therefore, the scale can be used by the academicians in further researches. Furthermore, this study may be considered as a beginning point in Turkey related to revealing the social media user typology. Over a period of time, this study can take the form of a longitudinal study, so that the developments or changes in preferences of social media users in Turkey can be detected. In addition; since the Internet technology improves daily and social media is expands with the establishment of new social web sites, the study may be revised and improved taking into consideration the new social media activities. The study may also be applied to other foreign countries and the differences in social media 
usage preferences among the countries can be explicated. Furthermore, a study related to exploring the motivations that make the users follow companies on social media can be conducted, thus the companies which aim to be on social media and be followed by the users may form their strategies through the results of the study.

\section{Limitations of the Study}

Although this study has established important findings, there are some limitations to be acknowledged. The first one is the usage of the convenience sampling method in order to reach respondents because of the time and budget limitations. In addition, it is very hard to get the list of all internet users in Turkey because some people use only free Wi-Fi points, some people share the Internet with their friends or neighbors, and some people just use the $3 \mathrm{G}$ mobile internet connections. Therefore, reaching all the internet users and conducting a probability sampling is practically impossible. Thus, the nonprobability sampling method which was used in this study influences the generalization of the study. 


\section{REFERENCES}

\subsection{BOOKS}

Akar, E. (2010), Sosyal Medya Pazarlaması, Sosyal Web’de Pazarlama Stratejileri. Ankara: Elif Publishing Company.

Boone, L. E., D.E. Kurtz, H.F. Mackenzie, K. Snow (2009), Contemporary Marketing. Second Edition. U.S.A.: Nelson Education Ltd.

Eley, B., \& Tilley, S. (2009). Online Marketing Inside Out. Melbourne: SitePoint.

Everitt, B.S., S. Landau, M. Leese, D. Stahl (2009). Cluster Analysis. U.S.A.: Wiley Inc.

Funk, T. (2009), Web 2.0 and Beyond, Understanding the New Online Business Models, Trends and Technologies. Westport: Greenwood Publishing Group.

Gegez, E. (2007), Pazarlama Araştırmaları. Second Edition. Istanbul: Beta Publishing Company.

Gillmor, D. (2004). We the Media. Sebastopol, CA: O'Reilly Media, Inc.

Grebitus, C., (2008). Food Quality from the Consumers' Perspective. Germany: Cuvillier Verlag.

Grover, R., M. Vriens (2006), The Handbook of Marketing Research. London: Sage.

Gunelius, S. (2011), 30 Minute Social Media Marketing: Step by Step Techniques to Spread the Words about your Business. U.S.A.: McGraw-Hill.

Hair, F. J., W. Black, B. Babin, R. Anderson (2010), Multivariate Data Analysis: A Global Perspective. U.S.A.: Pearson.

Halligan, B., D. Shah. (2010). Inbound Marketing, U.S.A.: John Wiley \& Sons, Inc. 
Jackson, S. L., (2008), Research Methods: A Modular Approach. First Edition. U.S.A.: Cengage Learning.

Jaokar, A., B. Jacobs, A. Moore and J. Ahvenainen. (2009). Social Media Marketing: How Data Analytics Helps to Monetize the User Base in Telecoms, Social Networks, Media and Advertising in a Converged Ecosystem. London: Futuretext.

Keller, K. L. (2007), Strategic Brand Management: Building, Measuring, and Managing Brand Equity. Third Edition. U.S.A.: Pearson.

Kotler, P., \& Keller, K. L. (2007). A Framework For Marketing Management. Third Edition. New Jersey: Pearson/Prentice Hall.

Kotler, P., Keller, K.L. (2006). Marketing Management. $12^{\text {th }}$ Edition. New Jersey: Pearson Prentice Hall.

Kurtuluş, K. (2004), Pazarlama Araştırmaları. Istanbul: Literatur Publishing Company.

Kurtz, D. L. (2008), Contemporary Marketing, $13^{\text {th }}$ Edition, Ohio: Thomson Inc.

Malhotra, N. K., M. Peterson (2006), Basic Marketing Research: A Decision-Making Approach. Second Edition. New Jersey: Pearson/Prentice Hall.

Mazzocchi, M (2008), Statistics for Marketing and Consumer Research, U.K.: Sage.

McKee, S. (2010), Creative B2b Branding (No, Really): Building a Creative Brand in a Business World. U.S.A: Goodfellow Publishers Limited.

Nisbet R., J. Elder, G. Miner (2009), Handbook of Statistical Analysis \& Data Mining Applications. U.S.A.: Elsevier Inc.

Nunally, J., (1967). Psychometric Theory. New York: McGraw Hill.

Odabaşı, K and A.K. Odabaşı, (2010), Internette Pazarlama ve Sosyal Medya Stratejileri, Istanbul: Cinius Publishing Company. 
Pett, M.A., N. R. Lackey, J.J.Sullivan (2003), Making Sense of Factor Analysis: The Use of Factor Analysis for Instrument Development in Health Care Research. U.S.A.: Sage.

Romesburg, H.C. (2004), Cluster Analysis for Researchers. U.S.A.: Lulu Press.

Safko, L., D.K. Brake, (2009). The Social Media Bible. New Jersey: John Wiley \& Sons, Inc.

Saunders, M., P. Lewis, A. Thornhill, (2007). Research Methods for Business Students. Forth Edition. England: Pearson.

Scott, D. M. (2010), The New Rules of Marketing and PR: How to use Social Media, Blogs, News releases, Online Video and Viral Marketing to Reach Buyers Directly. New Jersey: John Wiley and Sons Inc.

Scott, D., M. (2010). The New Rules of Marketing and PR. Second Edition. U.S.A.: John Wiley \& Sons, Inc.

Tuten, T.L. (2008), Advertising 2.0: Social Media Marketing in a Web 2.0 World, Westport: Preager.

Vollmer, C., Precourt, G. (2008). Always On: Advertising, Marketing, and Media in an Era of Consumer Control. New York: McGraw-Hill.

Weber, L. (2007), Marketing to the Social Web: How Digital Customer Communities Build Your Business. New Jersey: John Wiley and Sons Inc.

Weinberg, T (2009), The New Community Rules: Marketing on the Social Web. First Edition. California: O’Reilly Inc.

Zarrella, D. (2010), The Social Media Marketing Book. California: O’Reilly Media Inc. 


\subsection{ARTICLES}

Akman, I, S. Misra, T. Altindag, (2011), the Impact of Cognitive and SocioDemographic Factors at Meetings during Software Development Process. Technical Gazette 18, 1, p: 51-56.

Barker, V. (2009). Older Adolescents' Motivations for Social Network Site Use: The Influence of Gender, Group Identity, and Collective Self-Esteem. Cyber Psychology \& Behavior, 12(2), 209-213.

Barsky, E., M. Purdon (2006). Introducing Web 2.0, Social Networking and social Bookmarking for Health Librarians. The Journal of the Canadian Health Libraries Association, Vol.: 27, pp: 65-67.

Boyd, D. and N.Ellison (2007). Social Networking Sites: Definition, History, and Scholarship, Journal of Computer-mediated Communications, Vol. 13 No. 1, pp. 210-30.

Carmode, G; B. Krishnamurthy (2008). Key Differences between Web1.0 and Web2.0. First Monday, 13(6), June 2008.

Constantinides, E., S. J. Fountain (2010), Web 2.0: Conceptual foundations and marketing issues. Journal of Direct, Data and Digital Marketing Practice (2008) 9, 231-244.

Cooke, M, N. Buckley (2007). Web 2.0, Social Networks and the Future of Market Research. International Journal of Market Research Vol. 50 Issue 2.

Dunne, A, M.A. Lawlor, J.Rowley (2010). Young people's use of online social networking sites - a uses and gratifications perspective. Journal of Research in Interactive Marketing, Vol:4 No:1 pp: 46-58.

Goodchild, M. F. (2007). Citizens as Voluntary Sensors: Spatial Data Infrastructure in the World of Web 2.0. International Journal of Spatial Data Infrastructures Research, Vol. 2, 24-32. 
Haridakis P., G. Hanson (2009). Social Interaction and Co-Viewing with YouTube: Blending Mass Communication Reception and Social Connection. Journal of Broadcasting \& Electronic Media 53(2), pp. 317-335.

Harris, L., A. Rae (2009). Social Networks: The Future of Marketing for Small Business. Journal of Business Strategy, Vol. 30 No. 5 2009, pp. 24-31.

Kaplan, M, A.,M. Haenlein (2009), Users of the world, unite! The challenges and opportunities of Social Media, Business Horizons 53, 59-68.

Katz, E. (1959). Mass Communication Research and the Study of Popular Culture. Studies in Public Communication, 2, 1-6.

Kozinets, R.V., (2002). The Field Behind the Screen: Using the Method of Netnography To Research Market-Oriented Virtual Communities. Journal of Marketing Research Vol.: 39, pp. 61-72.

Lee, T.T. (2004). Evaluation of Computerized Nursing Care Plan: Instrument Development. Journal of Professional Nursing, Vol 20, No 4 pp 230-238.

Leiner at al. (2009). A Brief History of the Internet. ACM SIGCOMM Computer Communication Review, Volume 39, Number 5, October 2009.

Lerman, K. (2007). Social Information Processing in News Aggregation. IEEE Internet Computing, v.11 n.6, p.16-28, November 2007.

Mangold W. G., D. J. Faulds, (2009), Social Media: The New Hybrid Element of the Promotion Mix, Business Horizons (2009) 52, 357-365.

Newhagen, J., \& Rafaeli, S. (1996). Why Communication Researchers Should Study The Internet: A Dialogue. Journal of Communication, 46, 4-13.

Raacke, J. and J.B. Raacke (2008). MySpace and Facebook: Applying the Uses and Gratifications Theory to Exploring Friend-Networking Sites. Cyber Psychology \& Behavior, volume 11, Number 2, 2008. 
Rubin, A.M. (1994). Media uses and effects: A uses and gratifications perspective. In J. Bryant \& D. Zillmann (Eds.), Media effects: Advances in theory and research pp. $417-456$.

Sheldon, P. (2008). Student Favorite: Facebook and Motives for Its Use. Southwestern Mass Communication Journal. Spring, 2008.

Tikkanen, H., J. Hietanen, T. Henttonen, and J.Rokka. (2009). Exploring Virtual Worlds: Success Factors in Virtual World Marketing. Management Decision, Vol. 47 No. 8, pp. 1357-1381.

Urista, M. A., Q. Dong and K. D. Day. (2009). Explaining Why Young Adults Use MySpace and Facebook Through Uses and Gratifications Theory. Human Communication. A Publication of the Pacific and Asian Communication Association. Vol. 12, No. 2, pp.215 - 229.

Zhang, Z, K. Cheung, J.P. Townsend (2008). Bringing Web 2.0 to Bioinformatics. Briefings in Bioinformatics (Oxford Journals), Vol.: 10, No:1, pp: 1-10.

\subsection{INTERNET SOURCES}

Aharony, N. (2008), "Web 2.0 in U.S. LIS Schools: Are They Missing the Boat?", Ariadne, Issue:54, retrieved in $18^{\text {th }}$ February, 2011, from http://www.ariadne.ac.uk/issue54/aharony/

Akbaba, H (2010), Türkiye'de Sosyal Medya Kullanım Analizi (Social Media Usage Analysis in Turkey), retrieved in $20^{\text {th }}$ May, 2011 from http://www.sosyalmedyapazarlama.com/2010/11/30/turkiyedesosyalmedyakull animanalizi/?utm_source=twitterfeed\&utm_medium=twitter\&utm_campaign= Feed\%3A+SosyalMedyaPazarlama+\%28Sosyal+Medya+Pazarlama\%29.

Alexa (2010), retrieved in $21^{\text {st }}$ May, 2010, from http://www.alexa.com/siteinfo/facebook.com\#

Alexa (2010), retrieved in $21^{\text {st }} \mathrm{Jun}, 2010$, from http://www.alexa.com/topsites 
Alexa (2010), retrieved in $21^{\text {st }}$ May, 2010, from http://www.facebook.com/press/ info.php?statistics

Alexa (2010), retrieved in 22 ${ }^{\text {nd }}$ May, 2010, from http://www.alexa.com/topsites/global;1

Aschenbrenner, A., S. Miksch, (2005). Blog mining in a corporate environment, Smart Agent Technologies, retrieved in 20th Jun, 2010, from http://ieg.ifs.tuwien.ac.at/techreports/Asgaard-TR-2005-11.pdf

Babaoglan, A. (2007), Future of Internet Technologies \& Web 3.0 Seminar - Atılım University, retrieved in $15^{\text {th }}$ February, 2011, from http://www.alibabaoglan.com/index.php/about-me/seminars.html

Bain, D. (2011), The Evolving Web - The Future Of Internet Marketing - Internet Marketing Pillar \#13, retrieved in 20th May, 2011, from http://www.26weekplan.com/the-future-of-internet-marketing.html.

Cankaya, M.N. (2007), "Web 3.0”, retrieved in 21 $1^{\text {st }}$ February, 2011, from http://www.nuricankaya.com/default.asp?gunluk_id=168

Coon, M. (2010), Social Media Marketing: Successful Case Studies of Businesses Using Facebook and YouTube with an In Depth Look in the Business Use of Twitter", Communication M.A. Project, retrieved in $2^{\text {nd }}$ March, 2011, from http://comm.stanford.edu/coterm/projects/2010/maddy\%20coon.pdf

Creative Research Systems (2011), Sample Size Calculator, Retrieved in $8^{\text {th }}$ June, 2011 from http://www.surveysystem.com/sscalc.htm

D’Souza, N. (2009), “Social Media Marketing: Whopper Sacrifice”, retrieved in $2^{\text {nd }}$ March, 2011, from http://www.virtualeyesee.com/2009/06/whopper-sacrificefacebook-marketing/

Elkin (2010), MySpace Statistics, retrieved in 22 $2^{\text {nd }}$ May, 2010, from http://scottelkin.com/programming/aspnet-20/myspace-statistics/ 
Facebook, (2010), retrieved in 21 ${ }^{\text {st }}$ May, 2011, from http://www.facebook.com/\#!/press/info.php?factsheet

Famecount (2011), Top Facebook Pages, Turkey, retrieved in 25 May, 2011, from http://www.famecount.com/facebook-rank/Turkey.

Fouts, R (2010), How to Govern Social Media ...While Encouraging its Creative Use, Gartner Webinar, retrieved in $2^{\text {nd }}$ March, 2011, from http://www.gartner.com/it/content/1467500/1467513/december_7_how to_gov er_social_media_rfouts.pdf

Google Press, (2010), retrieved in 23rd May, 2010, from http://www.google.com/press/pressrel/google_YouTube.html

Googletrends (2011), retrieved in 24 May, 2011, from http://www.google.com /trends?q=facebook $\% 2 \mathrm{C}+$ youtube $\% 2 \mathrm{C}+$ twitter $\% 2 \mathrm{C}+$ stumbleupon $\& \mathrm{ctab}=0 \&$ ge $\underline{\mathrm{o}=\operatorname{tr} \& \text { date }=\text { all } \& \text { sort }=0}$

Gordhamer, S. (2009), "4 Ways Social Media is Changing Business", retrieved in $2^{\text {nd }}$ March, 2011, from Http://Mashable.Com/2009/09/22/Social-Media-Business/

Guzelkan, O. (2010), "Web 1.0 Nedir, Web 2.0 Nedir? Web 1.0 ve Web 2.0 Arasındaki Farklar Nelerdir?", retrieved in $15^{\text {th }}$ February, 2011, from http://ozanguzelkan.wordpress.com/category/internet-teknoloji/

McCarty, C. (2009), “The Dark Secrets of Whopper Sacrifice”, retrieved in $2^{\text {nd }}$ March, 2011, from http://news.cnet.com/8301-13577_3-10211898-36.html

Metz, C (2007), "Web 3.0", retrieved in 14 ${ }^{\text {th }}$ March 2011, from http://pedit.hio.no/ 1lektor/profile/docs/web_3.pdf PCMag Artice

O'Reilly, T., (2005), “O’Reilly — What Is Web 2.0,” (30 September), retrieved in $15^{\text {th }}$ April, 2011, from http://www.oreillynet.com/pub/a/oreilly/tim/news/2005/09/30/what-is-web20.html. 
O'Reilly, T., (2007). “Today's Web 3.0 Nonsense Blogstorm,” O'Reilly Radar (4October), retrieved in $15^{\text {th }}$ February, 2011, from http://radar.oreilly.com/archives/2007/10/web_30_semantic_web _web_20.html

O’Reilly, T., (2007), “What Is Web 2.0: Design Patterns and A Business Models for the Next Generation of Software", retrieved in $15^{\text {th }}$ February, 2011, from http://mpra.ub.unimuenchen.de/4578/1/MPRA_paper_4578.pdf

Onur Air Facebook 'da Uçuruyor (Onur Air makes Fly on Facebook) retrieved in $3^{\text {rd }}$ March, 2011, from http://www.onurair.com.tr/basin_bulteni21.aspx

Quelman, E. (2010), Socialnomics, retrieved in 2 Jun, 2011, from http://www.socialnomics.net/2010/05/05/social-media-revolution-2-refresh/

Scholz, T., (2008), "Market Ideology and the Myths of Web 2.0", First Monday, Volume 13, Number 3 - 3 March 2008, retrieved in $15^{\text {th }}$ February, 2011, from http://firstmonday.org/htbin/cgiwrap/bin/ojs/index.php/fm/article/viewArticle/2 $\underline{138 / 1945}$

Singh, B. (2010), Difference Between Web 1.0, Web 2.0, \& Web 3.0 - With Examples, retrieved in 30th, May from http://ezinearticles.com/?Difference-Between$\underline{\text { Web-1.0,-Web-2.0,-and-Web-3.0---With-Examples\&id=3683790. }}$

Social Media (2010), Web 2.0 and Internet Stats, retrieved in 20th Jun, 2010, from http://thefuturebuzz.com/2009/01/12/social-media-web-20-Internet-numbersstats/

Social Media Statistics (2010), retrieved in 23 ${ }^{\text {rd }}$ May, 2010, from http://trak.in/tags/business/2010/02/01/social-media-statistics-facebook-twitterflickr-linkedin

Socialbakers (2011), Facebook Brand Statistics in Turkey, retrieved in 25 May, 2011 from http://www.socialbakers.com/facebook-pages/brands/turkey/ 
Socialbakers (2011), Turkey Facebook Statistics, retrieved in 25 May, 2011 from http://www.socialbakers.com/facebook-statistics/turkey

Socialmediatr (2010), Türkiye'de Internetin Kisa Tarihi (Short Story of Internet in Turkey), retrieved in $18^{\text {th }}$ April, 2011 from http://www.socialmediatr.com/blog/turkiyede-internetin-kisa-tarihi/.

Statcounter (2011), “Top 7 Social Media Sites in Turkey” retrieved in 24 May, 2011, from http://gs.statcounter.com/\#social_media-TR-monthly-201004-201104

State Planning Organization (2010), Information Society Statistics of Turkey,2010, $\begin{array}{lllll}\text { retrieved } & \text { in } \quad 6^{\text {th }} & \text { April, } & \text { 2011, } & \text { from }\end{array}$ http://www.bilgitoplumu.gov.tr/Documents/1/Yayinlar/Information_Society_St atistics_2010.pdf

Suphakorntanakit, N. (2008), "Web 3.0", retrieved in 23 ${ }^{\text {rd }}$ February, 2011, from http://webuser.hs-furtwangen.de/heindl/ebte-08ss-web-20Suphakorntanakit.pdf

Trendweek (2010), Turkish Social Media Landscape 2010, retrieved in 20th May, 2011 from http://www.trendweek.com/turkiye-sosyal-medya-haritasi/

TUIK (Turkish Statistics Institute), the Research on Household Technology Usage Habit, 2010, News Bulletin, Volume: 148, $18^{\text {th }}$ of August 2010, retrieved in $30^{\text {th }}$ March, 2011, from http://www.tuik.gov.tr/PreHaberBultenleri.do?id=6308

Turkey's Statistical Yearbook (2009), retrieved in 30 ${ }^{\text {th }}$ March, 2011, from www.tuik.gov.tr/yillik/yillik.pdf

Vaynerchuk, G. (2008), “Social Segmentation”, Web 2.0 Expo Conference, September 16-19, NY retrieved in $3^{\text {rd }}$ March, 2011, from http://www.workingthree.com/features/social-segmentation/

Wikipedia (2011), Internet, retrieved in 30th May, 2011 from http://en.wikipedia.org /wiki/Internet 
Youtube, (2010), About Youtube, retrieved in 21 $1^{\text {st }}$ May, 2010, from http://www.YouTube.com/t/about

\subsection{OTHER SOURCES}

Anderson, P., (2007). What is Web 2.0? Ideas, Technologies and Implications for Education. JISC Technology and Standards Watch.

Burns, K. S. (2008). A Historical Examination of the Development of Social Media and Its Application to the Public Relations Industry. ICA Preconference, Montreal, Canada.

Clifford M., E. (2009). Viral marketing [Electronic version]. Revolution, 50-52.

Constantinides, E. (2009). Social Media / Web 2.0 as Marketing Parameter: An Introduction. Marketing Trends Congress, Paris.

Coon, M. (2010), Social Media Marketing: Successful Case Studies of Businesses Using Facebook and YouTube With An In-depth Look in the Business Use of Twitter", Communication M.A. Project, June 4, 2010.

Frey, B., Rudloff, S. (2010). Social Media and Impact on Marketing. Bachelor Thesis, Lulea University of Technology.

Garnyte, M., Perez, A. V. (2009). Exploring Social Media Marketing Towards a Richer Understanding of Social Media in Postmodernity. MA Thesis, Aarus School of Business.

Gibson, B., (2007). Enabling an Accessible Web 2.0. 16th International World Wide Web Conference. May 07-08, 2007, Banff, Canada.

Habib, M. C. (2006). Toward Academic Library 2.0: Development and Application of A Library 2.0 Methodology. Master Thesis, Chapel Hill, North Carolina.

Kinsella, S., A. Budura, G. Skobeltsyn, S. Miche, J. Breslin, K. Aberer, (2008). From Web 1.0 to Web 2.0 and Back -How did your Grandma Use to Tag? Tenth 
International Workshop on Web Information and Data Management (WIDM'08).

Li, C., J. Bernoff, R. Fiorentino, \& S. Glass, (2007). Social Technographics Mapping Participation in Activities Forms. A forrester research report. New York.

Mabry, E. F., (2010). Engaging Audiences: An Analysis Of Social Media Usage In Advertising. Unpublishes Master Thesis, Louisiana State University, Lousiana, U.S.A.

Mintz, J. (2006). Finding Sense in Social Networking Deals. The Associated Press. Retrieved from Lexis Nexis Database November 25, 2006.

Prilla, M., R. Carsten (2008). Finding Synergies: Web 2.0 and Collaboration Support Systems, Proceedings of the 8th International Conference on the Design of Cooperative Systems, pp. 35-41

Robinson, J. E.(2007). A Study of Social Media Marketing In North Carolina Special Libraries. Unpublished Master's Thesis, University of North Carolina at Chapel Hill, U.S.A.

Stileman, P. (2009). What Extent Has Social Media Changed the Relationship between Brand and Consumer. Dissertation of MA Advertising, Bucks New University.

Xu, G., W. Y. Ma (2006). Building Implicit Links from Content for Forum Search. SIGIR'06, August 6-11, 2006, Seattle, Washington, USA. 


\section{Appendix 1 - Questionnaire in Turkish}

\section{Sosyal Medya Kullanımına Yönelik Bir Araştırma}

Değerli katılımcı; Bu anket Marmara Üniversitesi Üretim Yönetimi ve Pazarlama Bölümü Yüksek Lisans tez çalışması kapsamında hazırlanmıştır. Çalışmanın amacı; sosyal medya kullanıcılarının davranış kalıplarını belirlemektir. Vereceğiniz cevaplar gizli tutulacak ve tamamen akademik amaçla kullanılacaktır. Soruları lütfen dikkatlice okuyunuz ve size en uygun gelen cevapları işaretleyiz. Katılımınız ve desteğiniz için çok teşekkür ederim...

Mesut ÇíçEK

1. İnternete ne sıklıkla giriyorsunuz?

\begin{tabular}{|l|l|l|l|}
\hline Günde 12 saat ve yukarıs1 & & Günde 3-4 saat & \\
\hline Günde 9-12 saat & & Günde 1-2 saat & \\
\hline Günde 5-8 saat & & Günde 1 saatten az & \\
\hline
\end{tabular}

2. İnternete genellikle hangi cihazla bağlanıyorsunuz? (Birden fazla şıkkı işaretleyebilirsiniz)

\begin{tabular}{|l|l|l|l|}
\hline Masaüstü bilgisayar & & Cep bilgisayarı / telefonu & \\
\hline Dizüstü bilgisayar & & Tablet / Pad bilgisayar & \\
\hline
\end{tabular}

3. Lütfen aşağıdaki sosyal medya* türlerini kullanım sıklığına göre işaretleyiniz.

\begin{tabular}{|l|l|l|l|l|l|}
\hline & $\begin{array}{c}\text { Hiçbir } \\
\text { Zaman }\end{array}$ & Nadiren & $\begin{array}{c}\text { Ara } \\
\text { Sira }\end{array}$ & $\begin{array}{c}\text { Çoğu } \\
\text { Zaman }\end{array}$ & $\begin{array}{c}\text { Her } \\
\text { Zaman }\end{array}$ \\
\hline $\begin{array}{l}\text { Sosyal paylaşım siteleri (Örn: Facebook, Myspace, } \\
\text { Bebo) }\end{array}$ & & & & & \\
\hline $\begin{array}{l}\text { İçerik siteleri (Örn: Youtube, Flickr, Slideshare, } \\
\text { Dailymotion) }\end{array}$ & & & & & \\
\hline Blog sayfalar & & & & & \\
\hline Forum siteleri (Örn:Donanimhaber, Forumturkiye) & & & & & \\
\hline Micro blog siteleri (Örn:Twitter) & & & & & \\
\hline $\begin{array}{l}\text { Sanal yaşam ve oyun siteleri (Örn: Second Life, } \\
\text { Knight) }\end{array}$ & & & & & \\
\hline
\end{tabular}

* Sosyal Medya: Kullanıcıların internet üzerinden diğer kullanıcılar ve firmalar ile iletişime geçtikleri sosyal paylaşım siteleri, forumlar, bloglar,mikrobloglar, içerik siteleri, sanal yaşam ve sanal oyun sitelerinin tümünün birden oluşturduğu mecraya verilen isimdir.

4. Lütfen sosyal medya araçlarını hangi amaçlar için kullandığınızı kullanım sıklığına göre işaretleyiniz.

\begin{tabular}{|l|c|c|c|c|c|}
\hline & Hiçbir & Nadiren & $\begin{array}{c}\text { Ara } \\
\text { Sira }\end{array}$ & $\begin{array}{c}\text { Çoğu } \\
\text { Zaman }\end{array}$ & $\begin{array}{c}\text { Her } \\
\text { Zaman }\end{array}$ \\
\hline Arkadaşlarımla ilişki içinde olmak & & & & & \\
\hline
\end{tabular}




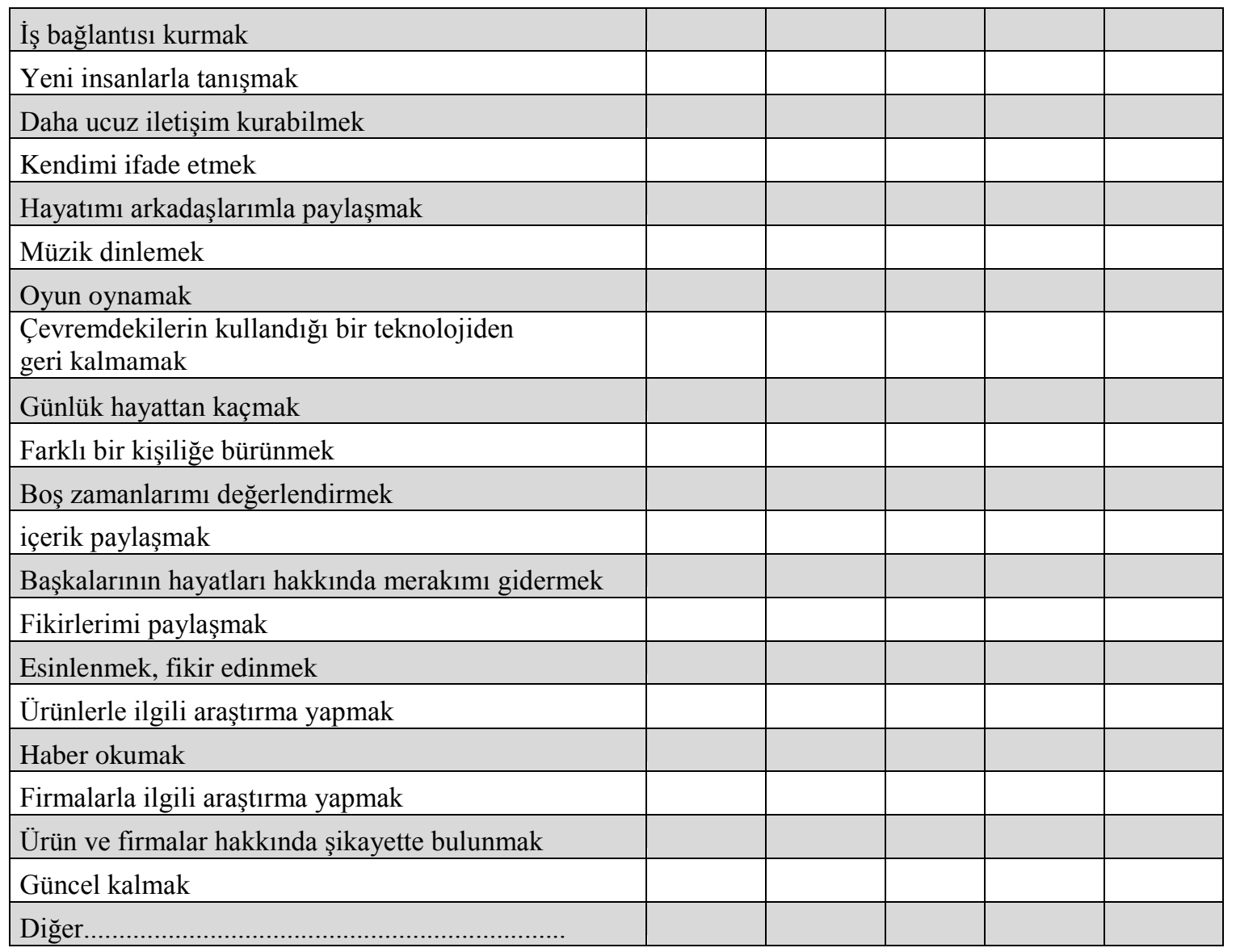

5. Lütfen Sosyal medya teknolojilerinin size sunduğu aşağıdaki aktiviteleri kullanım sıklığına gore işaretleyiniz

\begin{tabular}{|l|l|l|l|l|l|}
\hline & $\begin{array}{c}\text { Hiçbir } \\
\text { Zaman }\end{array}$ & Nadiren & $\begin{array}{c}\text { Ara } \\
\text { Sıra }\end{array}$ & $\begin{array}{c}\text { Çoğu } \\
\text { Zaman }\end{array}$ & $\begin{array}{c}\text { Her } \\
\text { Zaman }\end{array}$ \\
\hline Kendi blogumu yönetirim & & & & & \\
\hline Başkalarının bloglarını okurum & & & & & \\
\hline Başkalarının bloglarına yorum yaparım & & & & & \\
\hline Forumlarda konu başlıkları açarım & & & & & \\
\hline Forumlarda açılmış konu başlıklarına yorum yaparım & & & & & \\
\hline Forumlardaki konuları okurum & & & & & \\
\hline Sosyal paylaşım sitelerinde durumumu güncellerim & & & & & \\
\hline Kendi oluşturduğum içerikleri yüklerim (video, resim vb.) & & & & & \\
\hline Başkalarının yüklediği içerikleri paylaşırım & & & & & \\
\hline Paylaşılan içerikler hakkında yorum yaparım & & & & & \\
\hline Paylaşılan içeriklere bakarım. & & & & & \\
\hline İçeriklere kalitesine göre puan veririm & & & & & \\
\hline Sosyal paylaşım sitelerinde gruplara üye olurum & & & & & \\
\hline $\begin{array}{l}\text { Mikroblog (Twitter)sitelerinde durum güncellemesi } \\
\text { yaparım }\end{array}$ & & & & & \\
\hline Mikrobloglarda başkalarının yazdıklarına yorum yaparım & & & & & \\
\hline Mikrobloglarda başkalarının yazdıklarını okurum & & & & & \\
\hline Online oyunlar oynarım & & & & & \\
\hline Sanal dünyada bir karakter altında yaşam sürerim & & & & & \\
\hline
\end{tabular}


6. Lütfen sosyal medya sitelerinde paylaşılan aşağıdaki içerik kategorilerini paylaşım sıklı̆̆ınıza göre işaretleyiniz.

\begin{tabular}{|l|c|c|c|c|c|}
\hline & $\begin{array}{c}\text { Hiçbir } \\
\text { Zaman }\end{array}$ & Nadiren & $\begin{array}{c}\text { Ara } \\
\text { Sura }\end{array}$ & $\begin{array}{c}\text { Çoğu } \\
\text { Zaman }\end{array}$ & $\begin{array}{c}\text { Her } \\
\text { Zaman }\end{array}$ \\
\hline Amatör (Kullanıcıların kendi oluşturdukları içerikler) & & & & & \\
\hline Arabalar & & & & & \\
\hline Belgesel & & & & & \\
\hline Çizgi Film \& Animasyon & & & & & \\
\hline Sinema \& TV & & & & & \\
\hline Hayvanlar & & & & & \\
\hline Müzik & & & & & \\
\hline Oyunlar & & & & & \\
\hline Politika & & & & & \\
\hline Reklamlar & & & & & \\
\hline Sanat & & & & & \\
\hline Seyahat & & & & & \\
\hline Spor & & & & & \\
\hline Teknoloji & & & & & \\
\hline Ünlü Kişiler & & & & & \\
\hline Ürün incelemeleri & & & & & \\
\hline Diğer.................................................. & & & & \\
\hline
\end{tabular}

7. Lütfen sosyal medya sitelerinde hangi tür içerikleri paylaştığınızı, paylaşım sıklığınıza göre işaretleyiniz.

\begin{tabular}{|l|c|c|c|c|c|}
\hline & $\begin{array}{c}\text { Hiçbir } \\
\text { Zaman }\end{array}$ & Nadiren & $\begin{array}{c}\text { Ara } \\
\text { Sira }\end{array}$ & $\begin{array}{c}\text { Coğu } \\
\text { Zaman }\end{array}$ & $\begin{array}{c}\text { Her } \\
\text { Zaman }\end{array}$ \\
\hline Eğitici \& Öğretici & & & & & \\
\hline Komik & & & & & \\
\hline Romantik & & & & & \\
\hline Siradışı & & & & & \\
\hline Hüzünlü & & & & & \\
\hline Korkunç & & & & & \\
\hline
\end{tabular}

8. Firmaları sosyal medya siteleri aracılığı ile takip eder misiniz?

\begin{tabular}{|l|l|l|}
\hline Evet & Hayır \\
\hline
\end{tabular}




\begin{tabular}{|c|c|c|c|}
\hline 9. Cinsiyetiniz & 10. Ailenizin aylık toplam geliri & 11. Eğitim durumunuz & 12. Mesleğiniz \\
\hline$\square$ Bay & $\square \quad 0-999 \mathrm{TL}$ & $\square \quad$ İlköğretim & $\square \quad$ Öğrenci \\
\hline$\square$ Bayan & $\square \quad 1000-1999 \mathrm{TL}$ & $\square \quad$ Lise & $\square \quad$ Yönetici \\
\hline 13. Yaşınız & $\square \quad 2000-2999 \mathrm{TL}$ & $\square \quad$ Ön Lisans & $\square \quad$ İşçi \\
\hline$\square \quad 16-24$ & $\square \quad 3000-3999 \mathrm{TL}$ & $\square \quad$ Lisans & $\square \quad$ Memur \\
\hline$\square \quad 25-34$ & $\square \quad 4000-4999 \mathrm{TL}$ & $\square \quad$ Master-Doktora & $\square \quad$ Serbest Meslek \\
\hline$\square \quad 35-44$ & $\square \quad 5000-5999 \mathrm{TL}$ & 14. Medeni durumunuz & $\square$ Çiftçi \\
\hline$\square \quad 45-54$ & ㅁ $6000-6999 \mathrm{TL}$ & $\square$ Bekar & $\square$ Emekli \\
\hline ㅁ $55-64$ & 口 $7000-7999 \mathrm{TL}$ & $\square$ Evli & $\square$ Calıssmiyor \\
\hline$\square \quad 65-74$ & $\square \quad 8000+$ & Boşanmış & $\begin{array}{l}\square \text { Diğer } \\
\ldots \ldots \ldots \ldots . . .\end{array}$ \\
\hline
\end{tabular}




\section{Appendix 2 - Questionnaire in English}

\section{A Reseach on Social Media Usage}

1. How much time you spend on the Internet?

\begin{tabular}{|l|l|l|l|}
\hline Daily more than 12 Hours & & Daily 2-3 Hours & \\
\hline Daily 8-11 Hours & & Daily 1 - 60 Minutes & \\
\hline Daily 4-7 Hours & & & \\
\hline
\end{tabular}

2. Which tools do you use in order to connect to the Internet?

\begin{tabular}{|l|l|l|l|}
\hline PC & & Pocket PC /Mobile Phone & \\
\hline Notebook & & Tablet / Pad & \\
\hline
\end{tabular}

3. Please mark what are the motives of using social media tools according to frequency of use?

\begin{tabular}{|l|l|l|l|l|l|}
\hline & Never & Rarely & Sometimes & $\begin{array}{c}\text { Very } \\
\text { Often }\end{array}$ & Always \\
\hline Social Networking Sites & & & & & \\
\hline Content Communities & & & & & \\
\hline Blogs & & & & & \\
\hline Forums & & & & & \\
\hline Micro-Blogs & & & & & \\
\hline Virtual Worlds & & & & & \\
\hline
\end{tabular}

4. Please mark what are the motives of using social media tools according to frequency of use?

\begin{tabular}{|l|l|l|l|l|l|}
\hline & Never & Rarely & Sometimes & $\begin{array}{c}\text { Very } \\
\text { Often }\end{array}$ & Always \\
\hline Stay in touch with friends & & & & & \\
\hline Network for work & & & & & \\
\hline Meet new people & & & & & \\
\hline Cheaper Communication & & & & & \\
\hline Express myself & & & & & \\
\hline Keep my friends up to date with my life & & & & & \\
\hline Listen to music & & & & & \\
\hline Play games & & & & & \\
\hline Popularity & & & & & \\
\hline Escapism & & & & & \\
\hline Take on a different personality & & & & & \\
\hline Fill up spare time & & & & & \\
\hline Share content & & & & & \\
\hline Curiosity about others & & & & & \\
\hline Share my opinion & & & & & \\
\hline to get inspired/get ideas & & & & \\
\hline
\end{tabular}




\begin{tabular}{|l|l|l|l|l|l|}
\hline Research about products & & & & & \\
\hline Read news & & & & & \\
\hline Research on companies & & & & & \\
\hline Complain about products & & & & & \\
\hline Keep updated & & & & & \\
\hline Stay in touch with friends & & & & & \\
\hline
\end{tabular}

5. Please mark which of the activities provided by social media technologies according to frequency of use?

\begin{tabular}{|l|l|l|l|l|l|}
\hline & Never & Rarely & Sometimes & $\begin{array}{c}\text { Very } \\
\text { Often }\end{array}$ & Always \\
\hline I manage my own blog & & & & & \\
\hline I read others' blogs & & & & & \\
\hline I write comments on blogs & & & & & \\
\hline I create new topics on forums & & & & & \\
\hline I comment on existing forums & & & & & \\
\hline I read forums & & & & & \\
\hline I update my Status on social networking sites & & & & & \\
\hline I upload the self-created contents & & & & & \\
\hline I Upload Videos \& Pics of others & & & & & \\
\hline I comments on the contents & & & & & \\
\hline I look at the contents & & & & & \\
\hline I rate the contents according to their quality & & & & & \\
\hline I join the groups on social networking sites & & & & & \\
\hline I update my status on microblogs & & & & & \\
\hline I comment on others' tweets & & & & & \\
\hline I read others' tweets & & & & & \\
\hline I play online games & & & & & \\
\hline I maintain a character on virtual world & & & & \\
\hline
\end{tabular}

6. Please mark which content categories do you share in social media according to frequency of use

\begin{tabular}{|l|l|l|l|l|l|}
\hline & Never & Rarely & Sometimes & $\begin{array}{c}\text { Very } \\
\text { Often }\end{array}$ & Always \\
\hline Self contents & & & & & \\
\hline Cars & & & & & \\
\hline Documentaries & & & & & \\
\hline Cartoons/Animations & & & & & \\
\hline Movie/TV & & & & & \\
\hline Animals & & & & & \\
\hline Music & & & & & \\
\hline Gaming & & & & & \\
\hline Politics & & & & & \\
\hline Advertisements & & & & & \\
\hline Art & & & & & \\
\hline Travel & & & & & \\
\hline Sport & & & & & \\
\hline
\end{tabular}




\begin{tabular}{|l|l|l|l|l|l|}
\hline Technological & & & & & \\
\hline Celebrities & & & & & \\
\hline Review of products & & & & & \\
\hline Self contents & & & & & \\
\hline
\end{tabular}

7. Please mark which types of content do you share in social media according to frequency of use?

\begin{tabular}{|l|l|l|l|l|l|}
\hline & Never & Rarely & Sometimes & $\begin{array}{c}\text { Very } \\
\text { Often }\end{array}$ & Always \\
\hline Instructional videos & & & & & \\
\hline Funny & & & & & \\
\hline Romantic & & & & & \\
\hline Extraordinary & & & & & \\
\hline Tragic events & & & & & \\
\hline Horror & & & & & \\
\hline
\end{tabular}

8. Do you follow companies on social media?

\begin{tabular}{|l|l|l|l|}
\hline Yes & & No & \\
\hline
\end{tabular}

\begin{tabular}{|l|l|l|l|}
\hline 9. Gender & 10. Monthly Income & 11. Education & 12. Occupation \\
\hline$\square$ Male & $\square \quad 0-999 \mathrm{TL}$ & Elementary School & Student \\
\hline$\square$ Female & $\square \quad 1000-1999 \mathrm{TL}$ & High School & $\begin{array}{l}\text { White-Collar } \\
\text { Worker }\end{array}$ \\
\hline 13. Age & $\square \quad 2000-2999 \mathrm{TL}$ & Associate Degree & Blue-Collar Worker \\
\hline$\square \quad 16-24$ & $\square 3000-3999 \mathrm{TL}$ & Undergraduate & Civil Servant \\
\hline$\square 25-34$ & $\square \quad 4000-4999 \mathrm{TL}$ & Graduate/Doctorate & Self-Employment \\
\hline$\square 35-44$ & $\square 5000-5999 \mathrm{TL}$ & $\mathbf{1 4}$ Marital Status & Farmer \\
\hline$\square 45-54$ & $\square 6000-6999 \mathrm{TL}$ & $\square$ Single & Retired \\
\hline$\square 55-64$ & $\square 7000-7999 \mathrm{TL}$ & $\square$ Married & Unemployed \\
\hline$\square 65-74$ & $\square 8000+$ & $\square$ Divorced & Student \\
\hline
\end{tabular}

